UNIVERSIDADE FEDERAL DE MINAS GERAIS

FACULDADE DE LETRAS

PROGRAMA DE PÓS-GRADUAÇÃO EM ESTUDOS LINGUÍSTICOS

Rafael Batista Andrade

SEMIÓTICA, ÉTHOS E GÊNEROS DE DISCURSO NAS CANÇÕESPOEMAS DE MARIA BETHÂNIA

BELO HORIZONTE

2012 
Rafael Batista Andrade

\title{
SEMIÓTICA, ÉTHOS E GÊNEROS DE DISCURSO NAS CANÇÕES- POEMAS DE MARIA BETHÂNIA
}

\author{
Dissertação apresentada ao Programa de Pós- \\ Graduação em Estudos Linguísticos da Faculdade de \\ Letras da Universidade Federal de Minas Gerais, \\ como requisito parcial para a obtenção do título de \\ Mestre.
}

Área de concentração: Teorias do texto e do discurso Linha de pesquisa: Análise do Discurso (2B).

Orientadora: Prof $^{a}$. Dr ${ }^{\mathrm{a}}$. Glaucia M. Proença Lara.

Belo Horizonte

Faculdade de Letras da UFMG 


\section{Universidade Federal de Minas Gerais}

\section{Faculdade de Letras}

Programa de Pós-Graduação em Letras: Estudos Linguísticos

A dissertação intitulada "Semiótica, éthos e gêneros de discurso nas canções-poemas de Maria Bethânia”, de autoria de Rafael Batista Andrade, foi aprovada pela banca examinadora constituída dos seguintes professores:

Prof ${ }^{\mathrm{a}}$. Dra Janaína de Assis Rufino - UEMG

Prof $^{a}$. Dr ${ }^{\mathrm{a}}$. Ana Cristina Fricke Matte - FALE-UFMG

Prof $^{\mathrm{a}}$. Dr ${ }^{\mathrm{a}}$. Glaucia Muniz Proença Lara - FALE-UFMG (Orientadora)

Belo Horizonte 


\section{AGRADECIMENTOS}

À Prof ${ }^{a}$. Dr ${ }^{\mathrm{a}}$. Glaucia Muniz Proença Lara, pela atenção em todo processo requerido na execução desta pesquisa.

Aos professores do POSLIN com os quais tive o prazer de fazer as disciplinas que contribuíram tanto para minha formação.

Aos professores do PROLEITURA e da minha Graduação que sempre me incentivaram a trilhar os caminhos da pesquisa.

Ao CNPq, pela concessão da bolsa de estudo.

Aos amigos e familiares. 
“Tu que és pássaro e és fonte, tua arte feita passo, traço e canto lança suas redes sobre nós que em penumbra e espanto te contemplamos. Teu fervor desenha uma paisagem onde seremos deuses, cravada a tua voz em nossa alma.

No exílio desse palco pairas sobre nós, diante de nós te acendes: como faríamos, transidos e encantados, se tivéssemos a chama que te queima e esse dom de ser rio e de ser ponte" (LYA LUFT, 2010, p. 55) 


\section{RESUMO}

Neste trabalho, analisamos sete canções e sete poemas, que, por meio da enunciação da cantora da MPB Maria Bethânia, tornaram-se sete canções-poemas. Situando nossa análise, prioritariamente, no nível discursivo do percurso gerativo de sentido proposto pela Semiótica do Discurso (Francesa ou Greimasiana), apreendemos, através dos temas e das figuras do componente semântico, as formações discursivas e ideológicas que incidem sobre as cançõespoemas e concorrem, juntamente, com outros elementos para a caracterização do éthos da intérprete. Voltamo-nos ainda para as problemáticas que envolvem a noção de gêneros de discurso, articulando à teoria bakhtiniana contribuições situadas na grande área da análise do discurso. Nossa investigação evidencia que a recorrente prática textual-discursiva de Maria Bethânia de mesclar poemas e canções produz efeitos de sentidos outros, relacionados, portanto, a um terceiro enunciador: o da Canção-Poema. Esse fato contribui para caracterizar a hibridização de textos desses dois gêneros como um novo texto, o que, por sua vez, nos remete aos estudos da autoria, abordada sob dois aspectos: o do éthos, já mencionado, e o do estatuto social do sujeito Maria Bethânia. O trabalho revela que Bethânia possui um éthos de intérprete com dimensões autorais, tornando-se, desse modo, uma intérprete-autora. Outra imagem projetada por ela, em seu discurso, é a de "erudita-carnavalesca". Isso nos leva a postular que, mais do que um mero recurso estilístico, a técnica adotada por Bethânia aponta para a possibilidade de surgimento de um novo gênero do discurso, com especificidades próprias, que o distinguem, portanto, dos gêneros canção e poema, tomados isoladamente.

PALAVRAS-CHAVE: temas; figuras; éthos; autoria; gêneros de discurso. 


\section{RÉSUMÉ}

Cette recherche a pour but d'analyser sept chansons et sept poèmes qui sont devenus sept chansons-poèmes par l'énonciation de Maria Bethânia, chanteuse de la MPB (musique populaire brésilienne). En situant l'analyse essentiellement sur le plan discursif du parcours génératif du sens proposé par la Sémiotique du Discours (ligne Française ou Greimassienne), on appréhende, à travers les thèmes et les figures de la composante sémantique, les formations discursives et idéologiques qui mettent l'accent sur les chansons-poèmes et concurrencent avec d'autres éléments pour caractériser l'ethos de l'interprète. On se penche aussi vers des questions qui entourent la notion de genres de discours, en articulant à la théorie bakhtinienne des contributions situées dans le champ de l'analyse du discours. Cette recherche montre que la pratique textuelle-discursive de Maria Bethânia de fusionner les poèmes avec les chansons produit un effet de sens autre, donc lié à un troisième énonciateur: celui de la ChansonPoème. Cela contribue à caractériser l'hybridation de ces deux genres de textes en tant que nouveau texte, qui, à son tour, nous amène à des études sur l'auctorialité, examinée sous deux aspects: l'ethos, déjà mentionné, et le statuts du sujet Maria Bethânia. Ce travail révèle que Bethânia a un ethos d'interprète avec des droits d'auteur, en devenant ainsi une interprèteauteur. En outre, Bethânia projette une autre image de soi dans son discours, celle de «savante-carnavalesque ». Cela nous amène à postuler que plus qu'un dispositif simple de style, la technique adoptée par Bethânia montre la possibilité de naissance d'un nouveau genre de discours, avec ses propres spécificités, qui le distinguent des genres chanson et poème, pris séparément.

MOTS-CLÉS: thèmes, figures, ethos, auctorialité; genres de discours. 


\section{SUMÁRIO}

INTRODUÇÃ

CAPÍTULO 1 - QUESTÕES METODOLÓGICAS E TEÓRICAS..................................... 12

1.1 A recorrência da canção-poema na trajetória artística de Maria Bethânia .................... 13

Os gêneros poema e canção: origens e transformações .................................................. 14

1.2.1 A canção: um resultado do processo urbanista ............................................................... 15

1.2.2 A lira ou o poema: um gênero literário por excelência ........................................................... 18

1.2.3 A canção e o poema: pontos de divergência social e uma tentativa de definição ....... 19

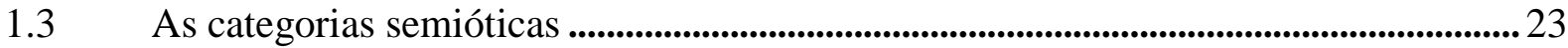

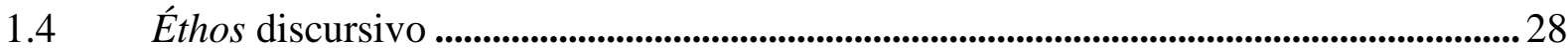

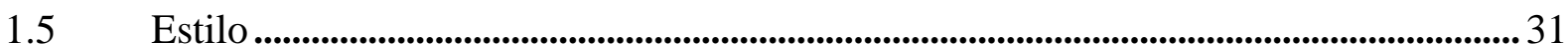

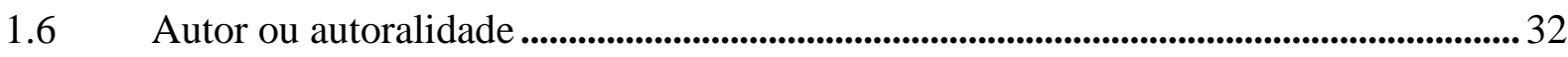

1.7 Problemáticas voltadas para o estudo dos gêneros de discurso ...................................... 35

CAPÍTULO 2: ANÁliSE dOS TEMAS E FIGURAS NAS CANÇÕES-POEMAS ........ 39

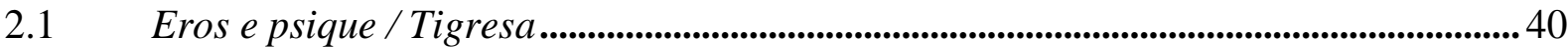

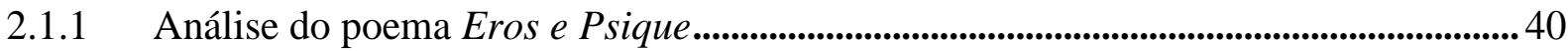

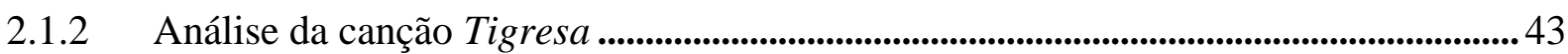

2.1.3 Análise de Eros e Psique / Tigresa: um terceiro texto..................................................... 45

O poeta come amendoim / Canto do Pajé ...................................................................................... 48

2.2.1 Análise do poema $O$ poeta come amendoim ........................................................................... 48

2.2.2 Análise da canção $O$ Canto do Pajé …..................................................................................51

2.2.3 Análise de O poeta come amendoim / O Canto do Pajé: um terceiro texto ................. 53

$2.3 \quad$ Pátria minhal Melodia sentimental ...................................................................................55

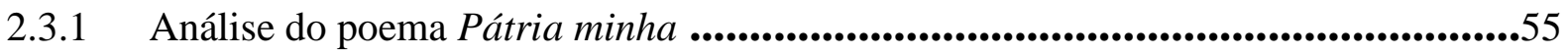

2.3.2 Análise da canção Melodia sentimental ................................................................................... 59

2.3.3 Análise de Pátria minha/ Melodia sentimental: um terceiro texto.................................. 61

$2.4 \quad$ Poema do menino Jesus/ Doce mistério da vida ...............................................................6 63

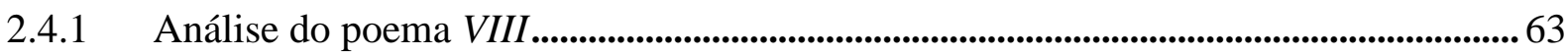

2.4.2 Análise da canção Doce mistério da vida .................................................................................... 70

2.4.3 Análise de Poema do menino Jesus / Doce mistério da vida: um terceiro texto......... 72

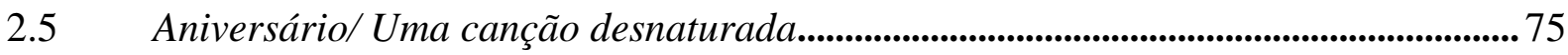

2.5.1 Análise do poema Aniversário .................................................................................................. 76 
2.5.2 Análise da canção Uma canção desnaturada ..................................................................... 79

2.5.3 Análise de Aniversário/Uma canção desnaturada: um terceiro tex to ............................. 83

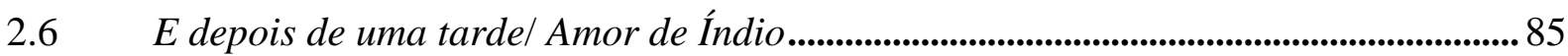

2.6.1 Análise do poema $E$ depois de uma tarde ........................................................................... 85

2.6.2 Análise da canção Amor de Índio ...................................................................................8 87

2.6.3 Análise de E depois de uma tarde/Amor de Índio: um terceiro texto ............................... 90

$2.7 \quad$ O Rio/ Francisco, Francisco _........................................................................................... 92

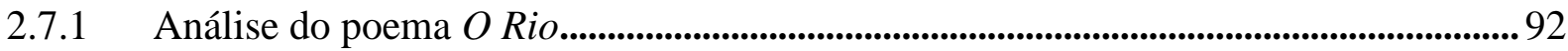

2.7.2 Análise da canção Francisco, Francisco ......................................................................... 94

2.7.3 Análise de $O$ Rio/ Francisco, Francisco: um terceiro texto ...........................................95

CAPÍTULO 3: ÉTHOS, ESTILO, AUTORIA E GÊNEROS DE DISCURSO................ 100

3.1 Análise do éthos da intérprete Maria Bethânia ........................................................... 100

3.2 Análise do estilo nas canções-poemas da intérprete Maria Bethânia............................ 104

3.3 Análise em torno da noção autor ou autoralidade........................................................... 105

3.4 Discussão de algumas problemáticas voltadas para o estudo dos gêneros .................111

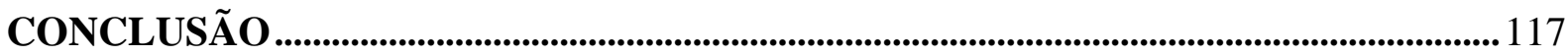

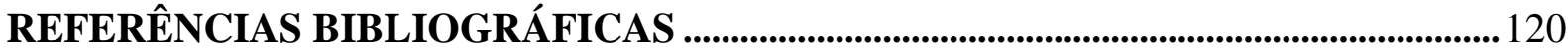

REFERÊNCIAS FONOGRÁFICAS......................................................................................127 


\section{INTRODUÇÃO}

A cantora brasileira Maria Bethânia muitas vezes interpreta algumas canções após a declamação/leitura de um ou de parte de um poema - às vezes lê também trechos de textos de outros gêneros literários ${ }^{1}$. Em trabalho anterior (ver ANDRADE, 2010), por meio da análise da canção Um índio, de Caetano Veloso, à qual se juntam partes do poema $O$ Navio Negreiro, de Castro Alves, analisamos esse fenômeno textual-discursivo, postulando que a união desses dois textos num mesmo espaço discursivo resulta num terceiro texto: uma canção-poema com uma nova configuração (e, portanto, com uma nova significação ou uma "ressignificação", a partir da significação individual dos textos mobilizados por Maria Bethânia).

Dando sequência a esse primeiro trabalho, a fim de aprofundá-lo e, em última análise, corroborar (ou não) as conclusões a que chegamos, pretendemos aqui analisar outras sete canções-poemas da cantora (intérprete) ${ }^{2}$ Maria Bethânia. Para isso, os textos escolhidos serão examinados à luz de algumas categorias da Semiótica Francesa que serão aliadas ao estudo do éthos, do estilo, da autoria e dos gêneros de discurso, considerando-se, nesse caso, autores/teorias que, situados na grande área de estudos do texto/do discurso, possam complementar e enriquecer a abordagem semiótica.

Podemos dizer que o eixo das problemáticas conceituais e teóricas aqui abordadas remete, de certa forma, a uma abordagem dos gêneros emergentes. Observamos que Marcuschi (2008, p. 198-206), um dos primeiros autores a tratar dessa questão no Brasil, dedicou-se, especialmente, aos gêneros oriundos do ambiente virtual. No caso desta pesquisa,

\footnotetext{
${ }^{1}$ Um exemplo disso é a mescla entre um trecho do gênero conto Barra da Vaca, de Guimarães Rosa, e uma canção, Cigarro de Paia, de Arnaldo Cavalcanti e Klecius Caldas, no CD Brasileirinho (BETHÂNIA, 2003), analisada em Andrade (2012).

${ }^{2}$ De acordo com Houaiss e Villar (2009, p. 1099), intérprete é "aquele que toca ou canta uma peça musical". Vemos, assim, que o termo cantor é mais restrito que o primeiro. Ressaltamos ainda que, em alguns dicionários especializados, não encontramos o termo intérprete, mas apenas interpretação. Nesse sentido, tanto Dourado (2004, p. 169) quanto Kennedy (1994, p. 350) salientam que, na interpretação, há implicações emotivas e julgamentos da personalidade do intérprete que ultrapassam as indicações mais formais (a partitura, por exemplo) de como uma música deve ser tocada ou cantada. Sabino (2010, p. 19), inclusive, lembra que Maria Bethânia prefere ser chamada de intérprete. Entretanto, como não há espaço neste trabalho para uma discussão mais profunda sobre essas terminologias e conceitos, o que exigiria a abordagem de vários aspectos (como aqueles que influenciam a interpretação: presença no palco, timbre de voz, mudanças melódicas e harmônicas etc.), tomaremos esses dois termos como equivalentes.
} 
deslocamos a questão para o domínio literário: uma das questões que pretendemos discutir aqui é a ideia de que a canção-poema seria um gênero emergente nesse/desse domínio.

Lembramos que, para a teoria semiótica, o texto se constrói na junção de um plano de conteúdo (o do discurso) com um plano de expressão - a(s) linguagem(ns) que veicula(m) o conteúdo -, sendo ambos os planos fundamentais na/para a construção de sentidos. Em se tratando de textos com função estética, como os que aqui examinamos, "a expressão ganha relevância, pois o escritor procura não apenas dizer o mundo, mas recriá-lo nas palavras, de tal sorte que importa não apenas o que se diz, mas o modo como se diz" (FIORIN, 2008b, p. 58). Embora concordemos com essa afirmação, decidimos priorizar, no presente trabalho, o plano de conteúdo verbal, concentrando nossas análises no nível discursivo do percurso gerativo de sentido, a nosso ver, ponto de imbricação entre as abordagens teóricas adotadas.

Diante desse quadro, nosso principal objetivo é estudar os processos de significação envolvidos na hibridização ${ }^{3}$ dos gêneros canção e poema em textos da discografia da cantora Maria Bethânia, examinando as novas configurações que eles assumem e os novos efeitos de sentido que propiciam. A esse objetivo maior, juntam-se outros, mais específicos, quais sejam: 1) refletir sobre o papel da intérprete na produção de sentido e a construção de seu éthos discursivo, discutindo essas questões à luz das noções de estilo e de autoria; 2) problematizar alguns conceitos advindos do estudo sobre gêneros de discurso, por meio do exame de novas configurações na enunciação dos gêneros poema e canção.

Para cumprir tais objetivos, estruturamos o presente trabalho como segue. No capítulo 1, discorreremos sobre as categorias teórico-metodológicas que selecionamos para a análise do corpus, que será apresentada e discutida nos capítulos 2 e 3. Optamos por essa divisão porque ela permite um melhor manuseio dos dados. Assim, reservamos o capítulo 2 apenas para a análise dos temas e figuras das sete canções-poemas, revelando suas respectivas formações discursivas e ideológicas. Já no capítulo 3, articularemos os dados analisados no capítulo precedente com as problemáticas sobre éthos, estilo, autoria e gêneros do discurso. Por último (capítulo 4), serão apresentados os resultados dessa análise conjunta dos capítulos 2 e 3.

\footnotetext{
${ }^{3}$ O termo "hibridização" está sendo tomado, no presente trabalho, como a articulação (ou junção) de dois gêneros distintos: a canção e o poema, num mesmo espaço textual.
} 


\title{
CAPÍTULO 1 - QUESTÕES METODOLÓGICAS E TEÓRICAS
}

\author{
"A análise do discurso parece ter mais condições de modificar \\ significativamente a maneira de se apreender a literatura que ela \\ aborda desde o início como discurso, dissolvendo as representações \\ tradicionais do texto e do contexto". (DOMINIQUE \\ MAINGUENEAU, 2001, p. 50)
}

Neste capítulo, dedicamo-nos à apresentação das etapas metodológicas e das categorias teóricas de que nos valemos para o desenvolvimento da pesquisa. Inicialmente, exporemos os procedimentos de seleção do corpus. Em seguida, abordaremos aspectos históricos que envolvem a canção e o poema, evidenciando alguns posicionamentos teóricos e apontando como os fatos expostos se articulam com os elementos teórico-analíticos que elegemos para a análise das canções-poemas. Por fim, discorreremos sobre os pressupostos teórico-metodológicos que norteiam as análises.

Antes, porém, apresentaremos alguns dados biográficos da intérprete. Nascida em 18 de junho 1946, em Santo Amaro da Purificação, Maria Bethânia recebeu esse nome por escolha de seu irmão Caetano Veloso, que tinha, na época, quatro anos de idade. No ano de 1963, Bethânia subiu ao palco pela primeira vez para cantar um samba de Ataulfo Alves. Em 1965, substituiu Nara Leão no espetáculo Opinião, de João do Vale e Zé Keti, no Rio de Janeiro. A partir daí, deu início a uma sólida carreira. Seu último CD (de estúdio), Oásis de Bethânia, foi lançado em $2011^{4}$.

\footnotetext{
${ }^{4}$ Dados disponíveis em: www.mariabethania.com. Acesso em: 25 jan. 2013.
} 


\subsection{A recorrência da canção-poema na trajetória artística de Maria Bethânia}

A primeira etapa da pesquisa consistiu no levantamento da ocorrência do "fenômeno" canção-poema na discografia da cantora/intérprete Maria Bethânia. Coletamos os dados em seu site oficial ${ }^{5}$, e, posteriormente, adquirimos a parte de sua extensa discografia em que tal fenômeno pode ser observado.

Por meio desse primeiro mapeamento, percebemos alguns aspectos essenciais para a realização desta pesquisa. A primeira ocorrência da hibridização canção-poema em disco de estúdio foi registrada em 1977. Já nos discos ao vivo que tivemos acesso, a primeira ocorrência apareceu em um CD de 1971. Ela permanece na obra de Maria Bethânia, de forma não linear, até os trabalhos mais recentes. Notamos ainda que tal fenômeno não é decorrente do fato de o CD ou o DVD ser ou não ao vivo, embora a ocorrência em gravações ao vivo seja mais frequente.

Uma observação importante para a delimitação do corpus foi a seguinte: com exceção do DVD Tempo, tempo, tempo, tempo (BETHÂNIA, 2005), os demais DVDs nos quais ocorre a hibridização canção-poema foram lançados também em CD com poucas alterações. No que diz respeito às canções-poemas, podemos mesmo dizer que não há alterações relevantes que influenciem a constituição do corpus. Por isso, optamos por realizar as análises somente a partir dos CDS. Além disso, acreditamos que a análise dos DVDs colocaria em evidência questões como a presença no palco e outros aspectos que compõem o cenário ou o espetáculo visual - e mesmo teatral - da perfórmance de Bethânia, que, para nos mantermos coerentes com os objetivos que norteiam esta pesquisa, precisariam ser excluídos.

Por se tratar de um conjunto extenso de canções-poemas, restringimos a análise a sete, cada uma delas extraída de um CD diferente, buscando atender à diversidade de autores mobilizados por Maria Bethânia ${ }^{6}$. A outra finalidade dessa seleção foi contribuir para a caracterização do éthos da intérprete, tanto do ponto de vista de uma tentativa de representação integral de sua obra, como de uma pequena amostra da variedade autoral dos poemas citados. Segue o quadro das canções-poemas selecionadas para esta pesquisa:

\footnotetext{
${ }^{5}$ Dados disponíveis em: http://www.mariabethania.com.br. Acesso em: 17 jan. 2011.

${ }^{6}$ Nessa diversidade autoral, incluímos também alguns heterônimos de Fernando Pessoa. Assim, temos Alberto Caeiro e Álvaro de Campos como autores, respectivamente, de Poema do menino Jesus e Aniversário. Lembramos que, com o uso da heteronímia, um autor visa "ocupar diferentes posições nos espaços discursivos de um determinado campo discursivo" (FIORIN, 2008a, p. 60).
} 
CDs de estúdio

\begin{tabular}{|l|l|l|l|}
\hline Nome do disco & Ano & Gravadora & Canções-poemas a serem analisadas \\
\hline Pássaro da manhã & 1977 & UNIVERSALMUSIC & Eros e Psique / Tigresa \\
\hline $\begin{array}{l}\text { Maria Bethânia } \\
\text { anos) }\end{array}$ & 1990 & UNIVERSALMUSIC & O poeta come amendoim / Canto do pajé \\
\hline Brasileirinho & 2003 & Biscoito fino & Pátria minha / Melodia sentimental \\
\hline
\end{tabular}

CDs ao vivo

\begin{tabular}{|l|l|l|l|}
\hline Nome do disco & Ano & Gravadora & Canções-poemas a serem analisadas \\
\hline Rosa dos ventos ao vivo & 1971 & UNIVERSALMUSIC & $\begin{array}{l}\text { Poema do menino Jesus / Doce mistério da } \\
\text { vida }\end{array}$ \\
\hline Imitação da vida & 1997 & EMI & Aniversário / Uma canção desnaturada \\
\hline Maricotinha ao vivo & 2002 & Biscoito fino & E depois de uma tarde / Amor de índio \\
\hline Dentro do mar tem rio & 2007 & Biscoito fino & O rio / Francisco, Francisco \\
\hline
\end{tabular}

Essas seleções remetem, antes de mais nada, a uma reflexão sobre a canção e o poema enquanto gêneros de discurso. Assim, embora não haja espaço para uma abordagem que envolva questões muito complexas sobre esses gêneros, no próximo item buscaremos contextualizá-los para que, pelo menos, fiquem claras as concepções de canção e poema que adotamos nesta pesquisa.

\subsection{Os gêneros poema e canção: origens e transformações}

Antes de apontar alguns dados históricos que revelam aspectos importantes sobre cada um desses gêneros, que serão articulados aos pressupostos teóricos por nós assumidos, acreditamos ser procedente uma breve exposição da relação entre música e literatura.

O vínculo entre essas duas áreas é visto por alguns estudiosos do tema pelo viés de um passado remoto, registrado historicamente quando dança, canto e poesia constituíam uma arte global, que, posteriormente, se segmentaria em sistemas distintos. De acordo com Oliveira (2002), a relação entre essas artes já podia ser vista nos séculos VI e V a. C. pelas referências mútuas que remetem a uma longa tradição. Ainda segundo a autora, tais referências perpassaram a crítica greco-romana e chegaram até nossos dias. Um exemplo disso é a citação que teria sido feita por Simônides de Ceos em "Sobre a Fama dos Atenienses": a pintura seria uma poesia muda; a poesia, uma pintura falante e a arquitetura, uma música congelada (PLUTARCH, apud OLIVEIRA, 2002, p.24). 
Hoje, a relação entre música e literatura pode ser vista de forma mais sistematizada, por exemplo, através da designação "melopoética". Algumas possibilidades de investigação nessa área poderiam ser resumidas em três grandes categorias. Nos estudos literário-musicais utiliza-se o instrumental dos estudos literários para a análise musical. Já os estudos músicos-literários procuram empregar conceitos advindos da musicologia para a análise literária. Por último, há os "estudos de formas mistas como a canção, a ópera e o lied, apoiados tanto na musicologia quanto nos estudos literários" (OLIVEIRA, 2002, p. 50).

Essas perspectivas teóricas apontam para a importância de estudos nessa área e revelam, por sua vez, a extensa problemática que se interpõe a vários estudiosos ${ }^{7}$. Apesar disso, em nosso trabalho, limitamo-nos a examinar a canção e o poema como gêneros de discurso, sem abordar outros aspectos a eles relacionados, como os que foram tratados nas obras selecionadas (ver nota 7). Isso porque a análise do discurso, domínio mais amplo em que se insere a presente pesquisa,

(...) visa apreender a estrutura dos enunciados através da atividade social que os carrega. Ela relaciona as palavras a lugares. Através da multiplicidade das situações de comunicação, o discurso eclode numa multiplicidade de gêneros, cujas condições de possibilidade, rituais e efeitos se devem analisar (MAINGUENEAU, 2001, p. 17).

Assim, alguns dados sócio-históricos da canção (ver 1.2.1) e do poema (ver 1.2.2) serão convocados apenas para ilustrar sua constituição enquanto gêneros de discursos ${ }^{8}$. Como esses dados são muitos, privilegiaremos aqueles que estão mais diretamente relacionados aos objetivos do presente trabalho.

\subsubsection{A canção: um resultado do processo urbanista}

Ao se perguntar sobre o surgimento da canção popular, Tinhorão (2011) põe em evidência, em primeiro lugar, a própria ambiguidade dessa nomenclatura, que não esclarecia a qual música se fazia referência: tratava-se da música do povo ou da música popular do mundo rural, estudada pelo folclore?

\footnotetext{
${ }^{7}$ Essa interposição, por sua vez, amplia os objetivos de análise, conforme se pode ver em obras como Palavra Cantada: ensaios sobre música, poesia e voz (MATOS; TRAVASSOS; MEDEIROS, 2008) e Leituras sobre música popular: reflexões sobre sonoridade e cultura (GIUMBELLI; DINIZ; NAVES, 2008).

${ }^{8}$ A noção de gênero de discurso será exposta, de forma detalhada, mais adiante (ver 1.3.5).
} 
As investigações realizadas por esse autor mostram a passagem do "cantar romance", próprio do final da Idade Média, para a denominada "modinha brasileira", gênero hoje conhecido, segundo ele, como música popular. Ainda de acordo com o autor, a música popular originou-se no intervalo entre os séculos XV e XVI, caracterizando-se como um, entre muitos, resultado do processo urbanista que anunciava o fim da economia rural, dominante na Idade Média. No século XVIII, uma variante do "cantar romance", posteriormente denominada pelo o autor "modinha brasileira", é levada a Portugal, onde ela, finalmente, "desponta como gênero reconhecível do que hoje chamamos música popular" (TINHORÃO, 2011, p. 12).

Essa mudança, que inclui o surgimento e a ascensão da burguesia, amplia, de forma considerável, as atividades econômicas nos grandes centros, como é o caso de Lisboa, acarretando novas necessidades de caráter social, como, por exemplo, a busca por novas formas de expressão pessoal, em que se incluíam as expressões musicais. O grupo que se dedicava a essas expressões imitava ou adaptava os gêneros e estilos literários daquele tempo, aproveitando os versos dos poetas para "trouar trouas que eram para ler", ou seja, dizer em voz alta os textos que eram apenas para serem $\operatorname{lidos}^{9}$ (TINHORÃO, 2011, p, 31). São essas experiências, segundo o autor, que resultaram, ao longo do século XVI, em muitas formas novas do fazer musical, em que se juntava canto e acompanhamento, constituindo um exemplo de melodia solista acompanhada.

Tinhorão (2011, p. 63-70) descreve ainda a recitação cantada de poemas épicos. Compara o canto solista às crônicas de acontecimentos lendários e heróicos que se constituíram com base no surgimento da literatura nacional no mundo moderno. A principal diferença está no fato de que, enquanto os versos feitos em latim e grego respeitavam medidas silábicas e de padrões longos e breves, o ritmo da fala das línguas derivadas do latim, que apareceram na Europa, estava relacionado ao caráter acentual das palavras, que seguia os saltos tônicos. O resultado foi a divisão do tempo entre duas tônicas consecutivas que passaram a ser contadas mentalmente como compassos, caracterizando o acompanhamento da moderna música das cidades, contemporânea do sistema tonal ${ }^{10}$.

\footnotetext{
${ }^{9} \mathrm{O}$ fato de Maria Bethânia declamar poemas não pode ser visto como uma volta a essa prática. Primeiro, porque hoje a canção já é tomada, sem nenhuma dúvida, como um gênero discursivo independente. Trata-se de uma prática intersemiótica em que texto e melodia são duas materialidades imbricadas e que está vinculada a uma comunidade discursiva que possui lugares específicos na formação social (cf. COSTA, 2002, p. 113). Segundo, porque sua declamação é um procedimento que desencadeia novos efeitos de sentido, ao se "misturarem" textos de gêneros distintos, como o poema e a canção.

10 Essas informações podem incentivar trabalhos voltados mais especificamente para o plano de expressão (verbal e não verbal/sonoro). Acreditamos, por exemplo, que uma abordagem histórica sobre a influência do
} 
O autor caracteriza o século XVIII como a época das "modas novas". De acordo com ele, o surgimento de tantas "modas novas" na música urbana acabou por configurar um tipo de composição, reconhecido por algo particular: a letra, o que preparou o terreno, no final desse século, "para o advento da moderna era das canções características da música popular das cidades" (TINHORÃO, 2011, p. 142). Assim, os cantores deixaram de entoar versos de outros gêneros, e a canção passou a ter um conteúdo verbal próprio e com restrições verbos-musicais. Levam-se em consideração, por exemplo, o caráter acentual das palavras e o sistema tonal.

Esses dados históricos foram mobilizados para que pudéssemos chegar a uma melhor compreensão da canção enquanto gênero discursivo hoje. Vimos, no parágrafo anterior, que a letra de música foi fundamental para uma relativa estabilidade da canção como gênero do discurso. É justamente esse fato que é recuperado por Tatit (1997, p. 102). De acordo com o autor, para se analisar esse gênero, sua clareza e completude dependem da verificação da "interdependência entre a melodia e a letra da canção", sendo que "se a reiteração e as tensões de altura servem para estruturar a progressão melódica, esses mesmos recursos podem ser transferidos ao conteúdo, de modo a construir uma significação compatível".

Assim, chegamos ao conceito de canção dentro de um quadro teóricometodológico inscrito em práticas discursivas. Os elementos constitutivos do gênero canção podem, portanto, ser caracterizados por uma "gramática rítmico-melódica” (TATIT, 1997, p. 102), que leva em consideração a interdependência de melodia e letra. Além disso, tomamos a canção popular brasileira urbana como produto de uma sociedade de consumo que está destinada ao entretenimento (MACHADO, 2012, p. 20). Essa posição, aliás, converge com o fato histórico de a origem da canção (popular brasileira) estar associada aos salões da corte portuguesa, o que mostra que não se trata de uma prática individualizada.

fazer poético do latim e do grego sobre a língua portuguesa pode revelar outros elementos distintivos entre os gêneros poema e canção. 


\subsubsection{A lira ou o poema: um gênero literário por excelência}

Sobre o poema, primeiramente temos que lembrar que se trata de um gênero literário. Não é nossa pretensão abordar aqui a questão dos gêneros literários. Essa problemática está inscrita na teoria da literatura e constitui-se como um campo de pesquisa independente. Para nós, entretanto, alguns apontamentos feitos por estudiosos dessa disciplina sobre o poema são valiosos, uma vez que permitem entender aspectos requeridos na abordagem desse gênero.

Sobre a categorização do gênero poema na Antiguidade, Soares (2000, p. 24) relembra que a lira (o poema) originou-se em oposição à epopeia. Esta se destinava ao cantar coletivo, à unidade da Polis, enquanto aquela surgia voltada para a expressão de sentimentos individualizados. Ainda segundo a autora, os cantares líricos,

\footnotetext{
(...) já em suas origens, vinham marcados pela emoção, pela musicalidade e pela eliminação do distanciamento entre o eu poético e o objeto cantado. Ao passar da forma somente cantada para a escrita, nesta se conservariam recursos que aproximariam música e palavra: as repetições de estrofes, de ritmos, de versos (refrão), de palavras, de sílabas, de fonemas, responsáveis não só pela criação de rimas, mas de todas as imagens que põem em tensão o som e o sentido das palavras (SOARES, 2000, p. 24).
}

Essa relação feita pela pesquisadora entre a lira (poema) e a música é bastante significativa, sobretudo se levarmos em conta o plano de expressão. Porém, como não é esse o foco deste trabalho, não nos ocuparemos dessa questão. Já o próximo dado abordado pela autora converge com os nossos propósitos.

Para Soares (2000, p. 26-29), o que diferencia aquele lirismo da Antiguidade do lirismo moderno são seus conteúdos: esse último teria, no seu entender, um conteúdo explicitamente social. Também faria parte do lirismo moderno, segundo ela, o metapoema, cujo conteúdo é a dessacralização da linguagem e do fazer poéticos. A pesquisadora exemplifica esse último caso citando o livro Psicologia da composição (MELO NETO, 1946/2008).

Vemos nesse último caso, a importância conferida ao plano de conteúdo na própria distinção dos modos do fazer poético. Essa relevância é ressaltada por Staiger, citado por Lima (2002, p.277-278): 


\begin{abstract}
A linguagem na lírica se mistura com a música, embora nela nunca se dissolva. $\mathrm{O}$ lírico então declara um encontro hipotético do eu com o outro, no qual a solidão da voz que fala conta, por assim dizer, com a simpatia do que lhe escuta. Encontro de solidões, "o lírico nos é instilado. Para que sua persuasão tenha êxito, o leitor precisa estar aberto. Está aberto quando sua alma está em sintonia com a alma do poeta. Assim, a poesia lírica se manifesta como arte da solidão, que em sua pureza, é escutada apenas por aqueles que estão de acordo na solidão".
\end{abstract}

Com isso, apreendemos o gênero poema enquanto prática discursiva, levando em consideração as expectativas que dele emanam: uma prática individual e intelectualizada, em que a persuasão é manifestada pela valoração de indivíduos que encontram na solidão da leitura a manifestação da arte.

\title{
1.2.3 A canção e o poema: pontos de divergência social e uma tentativa de definição
}

Não podemos esquecer-nos de que uma das críticas que a canção recebia, em sua gênese, estava centrada no conteúdo temático do texto verbal (letra). Hoje sabemos que não há discrepância temática entre os gêneros poema e canção, porém, a variabilidade de conteúdos atribuída ao poema parece apontar para questões relevantes, principalmente, quando imbricadas com outra particularidade desse gênero: a diferença entre poesia dramática, poesia narrativa (ou poesia épica) e poesia lírica, o que é visto, na análise do discurso, da perspectiva dos sujeitos da enunciação. Segundo Soares (2000, p. 12), "na representação dramática não haveria intervenção do poeta; líricas seriam as obras compostas somente pelas reflexões do próprio poeta; na poesia épica, ora falava o poeta, ora falavam as personagens introduzidas por ele”. A questão do(s) sujeito(s) é ainda mais relevante quando levamos em conta que:

\footnotetext{
A leitura solitária é o produto de uma civilização em que existem práticas culturais radicalmente individualizadas. Só pode existir interesse pela leitura e pela poesia num contexto em que a solidão radical do indivíduo seja socialmente valorizada e seja considerada produtiva por esse indivíduo. (MORICONI, 2002, p. 19-20).
}

Esse excerto mostra que, ao contrário do que ocorre na canção, o gênero poema tende para uma prática individualizada. De acordo com Moriconi (2002, p. 7), é essa prática que assegura o papel de intelectual, de letrado, visto que, no imaginário social, os poetas e os leitores de poesia seriam indivíduos singulares. Tal singularidade seria assegurada, no seu entender, pela mania de literatura, de cultivo das letras, mania, hoje, rara e considerada por 
muitos como ultrapassada. Para ele, é essa prática de leitura de bons romances, do descobrimento dos filósofos sérios, da aprendizagem do amor à literatura que permitiu o nascimento da tribo dos letrados. Em suma, o autor sugere que apenas numa sociedade que valoriza práticas individuais, há o papel social de intelectual ou letrado.

Tudo isso contribui para a caracterização do estatuto dos parceiros do gênero poema, o que está relacionado a expectativas sobre o éthos, quando se pensa, especificamente, na imagem projetada do enunciador. Ora, se "o simples fato de um texto estar ligado a um dado gênero do discurso ou a um certo posicionamento ideológico induz expectativas no tocante ao éthos" (MAINGUENEAU, 2006, p. 269), o poema criaria uma expectativa de éthos praticamente oposta à da canção. De acordo com o que vimos, nesta tem-se a imagem de um enunciador popular (pouco letrado), já naquele, a de um enunciador erudito, o que projeta imagens correlatas dos enunciatários. De fato, sobretudo no senso comum, uma pessoa pode ser qualificada de erudita ou letrada por ler poemas e pode ser até mesmo excluída de um grupo (tomado, por exemplo, como grupo de intelectuais) pelo fato de ouvir (certas) canções.

Ressaltamos que as características apontadas acima são expectativas projetadas sobre os gêneros canção e poema. Isso significa que não estamos fazendo juízos de valor, o que poderia denotar preconceito, mas tentando apreender as concepções de poema e canção tal como elas circulam no senso comum, até porque temos consciência de que as noções de erudito e popular não são estanques, mas modificam-se no tempo e no espaço. Acreditamos ainda que a própria designação MPB - Música Popular Brasileira - favorece a circulação dessas imagens.

Ainda que esses aspectos mostrem que os gêneros são, antes de mais nada, práticas discursivas inseridas no meio social, julgamos importante apresentar uma definição ou, pelo menos, algumas características básicas - dos gêneros canção e poema, que permita identificá-los e distingui-los. Esclarecemos que, nesse exercício, não temos qualquer pretensão de exaustividade.

Antes, porém, cabe ressaltar a dificuldade de se encontrarem definições que possam ser enquadradas nos postulados de uma teoria dos gêneros no âmbito da análise do discurso. Não queremos, com isso, desconsiderar a importância de pesquisas de outras áreas que tomaram esses gêneros como objeto de estudo, mas apenas destacar que esses outros quadros teóricos, nem sempre são fáceis de ser compatibilizados com as teorias que nos servem de base. Um exemplo dessas dificuldades pode ser visto na ausência do verbete canção no Dicionário de gêneros textuais (COSTA, 2009) e numa definição muito simples 
para o poema no verbete correspondente: "composição poética em versos, de tamanho muito variado" ${ }^{11}$ (COSTA, 2009, p. 167). Ao que parece, trata-se de gêneros tão presentes em nosso cotidiano que passa a ser desnecessário - até mesmo supérfluo - conceituá-los.

Comecemos as definições (ou as tentativas de definição) pelo poema, um gênero discursivo enquadrado no domínio literário, cuja finalidade é suscitar uma experiência estética $^{12}$ no interlocutor. Acreditamos que a presença da "musicalidade" no poema advém da prosódia. Assumimos com Greimas e Courtés (2011, p. 393) que "esse campo de pesquisa, ainda insuficientemente explorado, poderia ser um dos lugares de aproximação entre a semiótica poética e a semiótica musical”. Entretanto, considerando que a prosódia já faz parte da linguagem verbal, acreditamos tratar-se de um elemento que mantém relações privilegiadas com a linguagem musical. Além disso, lembramos que "um texto musical compreende uma exploração vertical da tessitura (alturas, tons, escalas, saltos etc.) e uma exploração horizontal que se dá no tempo e corresponde ao ritmo e ao andamento" (MATTE, 1998, p. 261). No caso do poema, o que geralmente alguns autores associam à "musicalidade" é apenas o ritmo ou o andamento, traços insuficientes para se afirmar que nele há uma linguagem musical; talvez seja mais adequado falar de "sonoridade" (advinda de recursos como ritmo, rima, assonâncias etc.). Caso diferente ocorre com a linguagem visual, que em certos momentos da tradição poética ganhou, inclusive, importância fundamental (como ocorre, por exemplo, com a poesia concreta).

Ainda que, atualmente, encontremos "versos livres" e a inexistência de rimas, quando pensamos num poema, logo o associamos à imagem cristalizada de um texto escrito (embora ele possa ser também sonoro, quando declamado, por exemplo), estruturado em versos metrificados que formam estrofes, em geral, organizados simetricamente e dispostos no centro ou na margem esquerda da página, o que remete à construção composicional como elemento importante na identificação do gênero poema.

Quanto ao estilo, ao defender a ideia de que, no caso dos gêneros, o que existe é um estilo verbal, constituído pelos "recursos lexicais, fraseológicos e gramaticais da língua", Bakhtin (2003, p. 261-262), adverte, no entanto, que, no caso dos gêneros de discursos enquadrados no campo artístico-literário, o estilo individual faz parte do texto/enunciado.

\footnotetext{
${ }^{11}$ É preciso observar que a dificuldade de definir alguns gêneros é ressaltada pelo próprio autor na apresentação do livro: “... há gêneros totalmente consagrados pela tradição e outros ainda carecem de pesquisas para que se possa detalhá-los com mais precisão" (COSTA, 2009, p. 11).

${ }^{12}$ Para Greimas (1987, p. 15-32), a experiência estética é um acontecimento extraordinário (uma "fratura") nos eventos cotidianos. Com ela, o tempo para, o espaço se fixa e produz-se uma "fusão" entre sujeito e objeto que estão disjuntos na temporalidade de todos os dias. O parecer imperfeito se rasga e surge a "nostalgia da perfeição", "escondida pela tela da imperfeição" que constitui a realidade cotidiana.
} 
Nesse caso, há que se levar em conta o conjunto da obra de um dado autor, o que revelará suas escolhas de figuras de linguagem (metáforas, antíteses, comparações, eufemismos, entre outras), de palavras (seleção lexical), a adoção de um viés mais ou menos subjetivo etc., enfim, o seu "estilo", o que, naturalmente, está relacionado à constituição do éthos desse autor. Afinal, para Bakhtin (2003), entre os gêneros mais aptos a refletir o estilo individual, encontram-se os literários.

O último traço distintivo que vamos mobilizar para definir o poema enquanto gênero de discurso é o suporte, cuja definição é a de "um lócus físico ou virtual com formato específico que serve de base ou ambiente de fixação do gênero materializado como texto" (MARCUSCHI, 2008, p. 174, grifo do autor). No caso de poemas escritos, o suporte convencional é o livro. Esse lócus físico, em que o poema comumente circula, também funciona como um aspecto de restrição. Por exemplo, a organização de um livro de poemas impõe restrições quanto à quantidade de poemas a ser publicada, à relação conceitual desse número de poemas, incluindo-se aí as mais variadas posições (temáticas, ideológicas, históricas etc.) assumidas pelo sujeito enunciador etc. Feita essa rápida caracterização do poema, vamos à canção.

Se não há dúvida de que o poema pertence ao domínio literário, essa mesma certeza não ocorre no caso da canção. Para alguns autores, tratar-se-ia de "paraliteratura", termo cunhado para abarcar os textos (como a canção) que não se enquadram no consenso literário social propriamente dito (HOUAISS; VILLAR, 2009, p.1431). Outros consideram-na inserida na literatura de massa, ao lado da novela, da lenda, da fábula etc. Sua finalidade é suscitar uma experiência verbo-musical de cunho popular em seu interlocutor. A canção articula, pois, primordialmente, a linguagem verbal e a linguagem musical, ainda que se possa falar também em linguagem visual, quando se considera a letra (escrita). Essas duas linguagens - a musical e a verbal - impõem restrições uma à outra. Por exemplo, uma canção com estrutura musical ABAB impõe uma construção verbal cuja seleção de recursos lexicais, gramaticais etc. comece e termine respeitando a primeira estrutura. A medida de um verso, então, não se apoia, necessariamente, na tradição poética (embora isso possa ocorrer), mas na medida da construção melódica em consonância com o sistema tonal.

No caso do estilo, assim como acontece com o poema, acreditamos poder falar em estilo individual, que se constitui mediante os recursos verbais (rimas, assonâncias etc.) e melódicos (alturas, tons, ritmo, andamento etc.) mobilizados, de forma recorrente, pelo autor (seja ele o compositor da melodia ou o letrista) num conjunto de textos musicais, o que, como dissemos, relaciona-se à constituição do éthos. Também no que diz respeito à construção 
composicional, se pensarmos na letra da canção, nosso objeto de estudo no presente trabalho (já que não estamos considerando o plano de expressão sonoro/musical), teremos uma disposição em versos e estrofes, bastante próxima à do poema.

Quanto ao suporte, acreditamos que o suporte por excelência da canção é o CD ou DVD. A estrutura mais frequente desse suporte é uma divisão bipolar, em que de um lado temos o encarte, e de outro temos o COMPACT DISC, ou seja, a mídia CD. No primeiro caso, geralmente, encontramos o texto verbal (reproduzido graficamente), apresentado em ordem numérica correspondente às faixas a serem reproduzidas na mídia. No segundo caso, temos a reprodução da canção que será captada oralmente. Além disso, também podem ser considerados como suporte da canção o rádio e a televisão, apesar de o próprio Marcuschi (2008, p. 180-181) afirmar que esses dois casos podem ser vistos tanto como suporte quanto meio e serviço. De qualquer forma, sem entrar na polêmica da distinção entre suporte e meio de transmissão, fato é que a canção é um desses gêneros que possui uma ampla circulação em nossa sociedade.

Outro dado relevante sobre o suporte da canção é que ela possui uma espécie de suporte específico para um público mais restrito, ou seja, para especialistas. Trata-se do livro (ou pasta, ou simplesmente uma partitura) de partituras. Nesse caso, temos "no papel" uma representação tanto do código linguístico como do código musical, sendo que ambos estão direcionados ao interlocutor especializado.

Feita essa rápida apresentação de alguns aspectos mais relevantes que caracterizam os gêneros canção e poema, exporemos, nos próximos itens, o arcabouço teórico-metodológico assumido para a análise do corpus. A ordem da exposição está baseada nos procedimentos de análise que foram se fazendo necessários, ao longo da pesquisa.

\subsection{As categorias semióticas}

O primeiro passo analítico que empreendemos relaciona-se a alguns princípios teórico-metodológicos da Semiótica do Discurso, que teve sua origem na França dos anos 1960. Essa teoria, desenvolvida por meio de pesquisas do Grupo de Investigações SemioLinguísticas da Escola de Altos Estudos em Ciências Sociais - Paris, teve como principal mentor o lituano, radicado na França, Algirdas Julien Greimas, razão pela qual é também denominada Semiótica Greimasiana. 
A Semiótica Francesa é uma teoria em construção, inacabada. Ela tem três fontes básicas em sua formação: a) uma fonte linguística - ancorada em Saussure e nos trabalhos do principal continuador do mestre genebrino: o linguista dinamarquês L. Hjelmslev - da qual extrai os princípios metodológicos estruturalistas (ainda que, progressivamente, ela integre também as propostas da linguística da enunciação, sobretudo as de Benveniste); b) uma fonte antropológica, em que divide com autores como V. Propp, C. Lévi-Strauss, M. Mauss e G. Dumézil, uma parte de seus objetos e de sua problemática, postulando, entre outras coisas, que, subjacente à diversidade empírica dos textos, encontramos um conjunto de relações simples e hierarquizadas (primado das relações estruturais sobre a realidade empírica dos objetos); c) uma fonte filosófica (a fenomenologia de E. Husserl e M. Merleau-Ponty), da qual extrai uma parte importante de sua concepção da significação (BERTRAND, 2003, p. 17-24).

Várias são as razões para que essa teoria tenha uma função privilegiada no presente trabalho. Mas, em resumo, é exatamente porque seu interesse está voltado para o "parecer do sentido" ${ }^{13}$, que se apreende pela análise das formas linguageiras e dos discursos que o manifestam (BERTRAND, 2003, p. 11). No caso da presente pesquisa, esse "parecer do sentido" é fundamental, pois a formação da canção-poema, ou seja, a hipótese de que os gêneros canção e poema, ao dialogarem, formam um novo texto (uma nova unidade de sentido), é baseada na abrangência ou na duplicidade desse "parecer do sentido". O que certamente é responsável também pelo éthos do enunciador/intérprete desses “objetos", senão a leitura prosseguiria apenas sob o viés dos enunciadores primeiros dos textos, tomados isoladamente. Além disso, a teoria possui uma proposta teórico-metodológica bastante eficaz, para o estudo do plano de conteúdo: o percurso gerativo de sentido.

Esse simulacro teórico-metodológico da produção/recepção de um texto divide-se em três níveis (fundamental, narrativo e discursivo) que se articulam e se complementam. Porém, além do plano de conteúdo, há também o plano de expressão, já que o texto surge da junção desses dois planos. O plano de expressão não tem um percurso gerativo solidamente estabelecido (como acontece com o plano de conteúdo) e conta com outras categorias para seu estudo que vão depender, em última análise, da(s) linguagem (ns) (verbal ou não verbal: visual, sonora, gestual etc.) utilizada(s) para veicular o conteúdo. Como já foi dito, o foco deste trabalho é o plano de conteúdo, pois nosso interesse maior é discutir "o parecer do

\footnotetext{
${ }^{13}$ Entende-se por essa expressão "uma abordagem relativista de um sentido, se não sempre incompleto, pelo menos sempre pendente nas tramas do discurso" (cf. BERTRAND, 2003, p. 21).
} 
sentido" que se constrói a partir da hibridização dos gêneros canção e poema e sua articulação com outras problemáticas, inseridas na grande área de análise do discurso, como a do éthos.

Para agilizar a exposição, falaremos brevemente dos níveis mais profundos - o fundamental e o narrativo - do percurso gerativo de sentido e nos deteremos mais no último nível - discursivo -, de onde vêm as categorias privilegiadas em nossa análise. Entende-se por nível fundamental a construção mínima de sentido, tendo em vista a geração do discurso. Temos aqui, portanto, uma ou mais categoria(s) semântica(s) de base, que opõe(m) dois termos, sobre os quais se aplica a categoria tímica, fazendo com que um deles seja positivo (eufórico) e o outro, negativo (disfórico). Essa operação é representada por um modelo lógico: o quadrado semiótico. Quando determinamos a(s) categoria(s) de base de um texto, estamos trabalhando com a semântica fundamental ${ }^{14}$. A sintaxe fundamental abrange as operações de negação e de asserção que permitem a obtenção dos termos contrários (por exemplo, /vida/ vs /morte) e contraditórios (por exemplo, /vida/ e /não vida/; /morte/ e /não morte/). Essas estruturas mais abstratas convertem-se, no nível subsequente, em estruturas narrativas.

No nível narrativo, ocorrem operações que, de certa forma, resumem a ação do homem no mundo: nele focalizam-se as relações entre sujeitos (que agem ou sofrem a ação de outros, que manipulam ou são manipulados, que julgam ou são julgados, que disputam objetos de valor etc.) e entre os sujeitos e os objetos. A unidade operatória básica da sintaxe narrativa é o programa narrativo (PN), categoria na qual um enunciado de fazer (que opera a passagem de um estado a outro) rege um enunciado de estado (conjunção ou disjunção do sujeito com o objeto). Os programas narrativos desdobram-se em quatro: manipulação, competência, perfórmance e sanção. Na primeira, há um contrato entre um destinadormanipulador e um destinatário-sujeito. As modalizações presentes, nessa etapa, são o querer e/ou o dever-fazer. Na competência, o sujeito, já manipulado, é modalizado por um saber e um poder-fazer, que lhe permitem passar, enquanto sujeito de fazer (ou sujeito operador), à perfórmance, isto é, à transformação central da narrativa. Por fim, na sanção, um destinadorjulgador avalia - por reconhecimento (sanção cognitiva), seguida ou não da premiação/punição (sanção pragmática) - se o sujeito de fazer cumpriu ou não o contrato estabelecido.

\footnotetext{
${ }^{14}$ Lembramos que todos os níveis do percurso gerativo de sentido são dotados de um componente semântico (os conteúdos investidos nos arranjos sintáticos) e um componente sintático ou sintáxico (os arranjos que organizam os conteúdos) (cf. FIORIN, 1995, p. 3).
} 
Ainda no nível narrativo (componente semântico), examina-se a modalização pelo ser e pelo fazer, bem como o jogo de compatibilidades e incompatibilidades entre as modalidades que afetam o sujeito de estado ${ }^{15}$ na sua relação com o objeto (de valor), o que desemboca na semiótica das paixões. Há as paixões simples - aquelas resultantes de um único arranjo modal: querer-ser - e as paixões complexas, em que as modalidades articulam-se em percursos que modulam a organização narrativa, como é o caso da cólera. Cabe distinguir ainda as paixões de objeto, ligadas à aquisição (ou não) dos valores desejados (satisfação, felicidade, tristeza etc.), das paixões de confiança (decepção, desconfiança, dúvida etc.), que envolvem a relação entre sujeitos (BARROS, 2003, p. 193).

O último nível é o discursivo. Nele, o sujeito passa a ser especificado como sujeito da enunciação: aquele que promove escolhas de pessoa, tempo e espaço; opta por temas e os recobre (ou não) com figuras, transformando, assim, a narrativa em discurso. É através desse procedimento que se chega, de forma mais completa, aos valores (à ideologia) investidos na construção textual, tendo em vista os efeitos de sentido que o texto deseja produzir.

A sintaxe discursiva examina: 1) as projeções da enunciação no enunciado; 2) as relações que se instauram entre enunciador e enunciatário. Quanto ao primeiro aspecto, afirma Barros (2008, p. 54) que "a enunciação projeta, para fora de si, os actantes e as coordenadas espaço-temporais, que não se confundem com o sujeito, o espaço e o tempo da enunciação". Nesse caso, temos dois procedimentos básicos: a debreagem, que pode ser enunciativa (quando se instalam no texto-enunciado um eu-aqui-agora) ou enunciva (quando, ao contrário, temos um ele-lá-então), e a embreagem, em que se neutralizam as oposições de tempo e/ou pessoa e/ou espaço (usa-se uma pessoa em lugar de outra, um tempo ao invés de outro etc.). O segundo aspecto apontado, por sua vez, volta-se para o estudo das relações (sobretudo argumentativas) que se instauram entre enunciador e enunciatário, ${ }^{16}$ tendo em vista que aquele realiza um fazer persuasivo que tem, como correlato, da parte do enunciatário, um fazer interpretativo. Assim, enunciador e enunciatário, entendidos, respectivamente, como

\footnotetext{
${ }^{15}$ Sujeito de fazer é aquele que realiza a perfórmance, enquanto sujeito de estado é aquele que entra em conjunção ou em disjunção com um dado objeto de valor pela ação do sujeito de fazer. Trata-se de papéis actanciais distintos (nível narrativo) que, no entanto, podem ser sincretizados por um mesmo ator (nível discursivo).

${ }^{16}$ Lembramos que há, num texto, basicamente três instâncias enunciativas hierarquizadas. A primeira é a do par enunciador/enunciatário, que correspondem ao autor e ao leitor implícitos ou abstratos, isto é, às imagens do autor e do leitor construídas na/pela obra. A segunda é a do par narrador/narratário, o "eu" e o "tu" instalados no texto-enunciado, que podem permanecer implícitos (como é o caso da narração em $3^{\text {a }}$. pessoa). Já quando o narrador dá voz, em discurso direto, aos personagens, temos, num terceiro nível da hierarquia enunciativa, o par interlocutor/interlocutário (cf. FIORIN, 2003, p. 163).
} 
destinador e destinatário do "objeto" de discurso, estabelecem um contrato de veridicção para a construção de sentido do texto, devendo-se, pois, estudar as estratégias de que o primeiro se vale para persuadir o segundo da "sua" (do enunciador) verdade.

Na semântica discursiva, ocorre a disseminação dos valores assumidos pelo sujeito da narrativa em percursos temáticos, que podem ainda ser revestidos por figuras, tornando-se percursos figurativos. Segundo Barros (2008, p. 69), tematizar um discurso consiste em "formular os valores de modo abstrato e organizá-los em percursos [...] para examinar os percursos devem-se empregar princípios da análise semântica e determinar os traços ou semas que se repetem no discurso e o tornam coerente". Ainda segundo a autora, "pelo procedimento de figurativização, figuras do conteúdo recobrem os percursos temáticos abstratos e atribuem-lhes traços de revestimento sensorial" (BARROS, 2008, p.72). Dentro do processo de figurativização, há ainda uma segunda etapa, denominada iconização. Nela, o enunciador investe na figura de forma exaustiva, a fim de produzir uma ilusão referencial, levando o enunciatário a reconhecê-la como uma "imagem do mundo". A importância da semântica discursiva está no estabelecimento da coerência textual através das isotopias temático-figurativas, que implicam a recorrência de traços semânticos (mais abstratos ou mais concretos) ao longo do discurso, estabelecendo-se, dessa forma, um (ou mais) plano(s) de leitura.

De acordo com Fiorin (1995, p. 9), um texto pode trabalhar melhor um nível do que outro, um componente do que outro, e é sobre esse(s) aspecto(s) mais explorado(s) que a análise deve centrar-se. Essa observação é bastante significativa para a nossa pesquisa porque, adotando agora a perspectiva do texto como objeto de comunicação, que sofre, portanto, determinações sócio-históricas, procuraremos inserir os textos do corpus no contexto ${ }^{17}$ de uma ou mais formações discursivas (FDs) e ideológicas (FIs), questão privilegiada pelo componente semântico do nível discursivo (e também pela chamada "Análise do Discurso de linha francesa", cujas contribuições assumimos neste trabalho). Nessa perspectiva, há que se analisar como se dá o enquadramento das FDs e FIs nos gêneros canção e poema separadamente e, em seguida, nas canções-poemas da intérprete Maria Bethânia.

\footnotetext{
${ }^{17}$ O termo "contexto" está sendo tomado, nesta pesquisa, de forma mais ampla do que o faz habitualmente a teoria semiótica, que, grosso modo, entende por essa noção, as relações intertextuais e interdiscursivas que um dado texto estabelece com outros textos. No entanto, considerando que o texto, além de ser um objeto de significação, é um objeto de comunicação, ele sofre, como foi dito, determinações (sociais, históricas, ideológicas...). Isso, por outro lado, não impede que também abordemos o "diálogo" entre textos/discursos, tanto aqueles que discutem informações contidas no texto-objeto, quanto aqueles que incidem sobre textos de um mesmo autor, de uma mesma obra ou de uma mesma época que se relacionam de forma privilegiada.
} 
Fiorin (2007, p. 21) afirma que "é no nível superficial, isto é, na concretização dos elementos semânticos da estrutura profunda, que se revelam, com plenitude, as determinações ideológicas". Ainda segundo o autor, é o próprio discurso, por meio de seus temas e figuras (tomados, em seu conjunto, como formações discursivas), que configura "a visão de mundo" do sujeito (do grupo/classe a que pertence), desvelando, pois, a formação ideológica em que esse sujeito se inscreve ${ }^{18}$. Trata-se, evidentemente, não do autor real (de carne e osso), mas sim do enunciador inscrito no discurso (autor implícito). Essa questão aponta para a instância da enunciação, o que nos levará a examinar também essa categoria da sintaxe discursiva.

Nesse caso, nos ocuparemos basicamente de três enunciadores: o enunciador do poema (EP), o enunciador da canção (EC) e o enunciador da canção-poema (ECP), que coincide com a intérprete Maria Bethânia. Assim, o exame dessas diferentes instâncias de enunciação (sintaxe discursiva) - somada à análise dos temas e figuras (semântica discursiva), que contribuem para o estabelecimento do contrato de veridicção entre enunciador e enunciatário - orientará o "parecer dos sentidos" do corpus, contribuindo para justificar a defesa do surgimento do texto híbrido canção-poema, e, consequentemente, para a articulação com os estudos do éthos, do estilo, da autoria e de problemáticas envolvidas na noção de gêneros discursivos, no quadro mais amplo da $\mathrm{AD}$ (análise do discurso). Esclarecemos, no entanto, que categorias de outros níveis do percurso gerativo de sentido - sobretudo o narrativo - poderão ser convocadas, de forma pontual, para auxiliar na análise dos textos selecionados.

\section{4 Éthos discursivo}

Como acabamos de ver, a análise dos temas e figuras, tomados como formações discursivas que, por sua vez, remetem às formações ideológicas, leva-nos a relacionar esses elementos com os enunciadores dos textos. Afinal, o sujeito que enuncia o faz de um determinado lugar (sócio-histórico-ideológico) e, ao fazê-lo, projeta uma determinada imagem de si, o que remete, em última análise, à investigação do éthos.

\footnotetext{
${ }^{18}$ Como se verá ao longo das análises, tomaremos os termos "formação discursiva" e "formação ideológica" na acepção que lhes atribui Fiorin (2007), numa releitura da AD pêcheutiana.
} 
A noção de éthos não é nova; ao contrário, remonta aos estudos feitos pela retórica clássica (Aristóteles). Nesse contexto, ela era vista como meio de persuasão em discursos orais dos gêneros deliberativo, judiciário e epidítico. Tal noção foi, no entanto, reformulada no quadro teórico da análise do discurso, ganhando, com isso, novas acepções.

Enquanto categoria discursiva, o éthos começou a ser estudado pelos teóricos franceses apenas a partir da década de 1980. Nesse primeiro momento, entende-se que sua construção ocorre no discurso, não sendo, portanto, uma imagem exterior à fala do enunciador. Tem ainda a característica de ser projetado por meio de um processo interativo, já que seu objetivo é influenciar o outro ${ }^{19}$.

Embora a noção de éthos proposta por Maingueneau (2008) não seja totalmente infiel à concepção aristotélica, ela ultrapassa a persuasão por meio de argumentos e "permite refletir sobre o processo mais geral da adesão dos sujeitos a um certo discurso" (ou melhor, a uma certa posição discursiva), manifestado oralmente ou por escrito (MAINGUENEAU, 2008, p. 17). Essa adesão é suscitada por uma maneira de dizer que é também uma maneira de ser.

O autor amplia, assim, a noção de éthos, relacionando-a também ao texto escrito. Além disso, em trabalhos mais recentes (ver MAINGUENEAU, 2006; 2008), postula a existência de um "éthos efetivo", que congregaria um éthos pré-discursivo ou prévio (aquele que se constitui antes mesmo que o sujeito "abra a boca") e um éthos discursivo, constituído, por sua vez, de um éthos dito (nível do enunciado: as informações que o orador dá de si mesmo) e um éthos mostrado (nível da enunciação: o "tom” que o discurso, mesmo escrito, assume: didático, enérgico etc.). Maingueneau altera, assim, a posição inicialmente assumida - mais compatível com a de Aristóteles - de que o éthos se construiria apenas no/pelo discurso.

Buscando relacionar a noção de éthos à Semiótica Francesa, reportamo-nos ao estudo de Cruz (2009), que faz exatamente essa articulação. Tínhamos visto, mais acima, que o éthos está relacionado à persuasão. Cruz (2009, p. 75), ao contextualizar essa noção em sua tese, lembra que "Greimas e Courtés definem o fazer-crer, ou persuasão, como a convocação, pelo enunciador, de toda sorte de modalidades com o objetivo de levar o enunciatário a aceitar

\footnotetext{
${ }^{19}$ De acordo com Maingueneau (1984), para além do que diz, o enunciador se deixa apreender por uma voz e um corpo. O autor propõe a designação do éthos como "tom", o que permite apreendê-lo em textos tanto orais quanto escritos. Além disso, segundo o autor, o éthos está relacionado à cena de enunciação, em que cada gênero discursivo tem papeis distribuídos que determinam parcialmente a imagem de si que o locutor constrói. Tal imagem ancora-se em estereótipos que apresentam certa eficácia em determinada cultura. (cf. MAINGUENEAU, 2008).
} 
o contrato enunciativo que lhe é proposto". O que ocorre, segundo o autor, por meio, basicamente, de estratégias narrativas e discursivas.

No nosso caso, como já dissemos, privilegiaremos as estratégias do nível discursivo. Vale lembrar, assim, que tanto os temas como as figuras não são escolhas neutras. Ao contrário, a seleção desses elementos acaba por revelar a ideologia, os valores da instância da enunciação e, consequentemente, permite desvelar o éthos do enunciador. Segundo Cruz (2009, p. 7), "é apenas a partir do que se conhece do enunciado que se pode apreender elementos acerca da instância da enunciação e, portanto, do enunciador". Ou dito de outra forma, nas palavras de Fiorin (2007, p.49):

\begin{abstract}
O sujeito inscrito no discurso é um 'efeito de sentido' produzido pelo próprio discurso, isto é, seus temas e suas figuras é que configuram a 'visão de mundo' do sujeito. Se, do ponto de vista genético, as formações ideológicas materializadas nas formações discursivas é que determinam o discurso, do ponto de vista da análise, é o discurso que vai revelar quem é o sujeito, qual é sua visão de mundo.
\end{abstract}

Outra questão aventada por Cruz (2009, p. 179) que também se mostra relevante para a nossa análise é a distinção entre enunciador e narrador ${ }^{20}$. Este, enquanto instância projetada no texto-enunciado, pertence à esfera da unidade, podendo, pois, ser apreendido em uma única obra ou texto. Já o enunciador (ou autor implícito), situado na instância da enunciação (e constituindo-se, pois, como fonte de valores) só se revela a partir de uma totalidade, isto é, mediante a análise do conjunto de sua obra. No caso do éthos de Maria Bethânia, cabe ressaltar a inviabilidade de se estudar, num tempo tão curto, a totalidade de sua obra. No entanto, a seleção das sete canções-poemas, a partir de diferentes obras, de diferentes momentos e buscando a diversidade de citações autorais, como propusemos, permite, a nosso ver, chegar ao - ou, pelo menos, aproximar-se do - éthos da cantora/enunciadora, sem que sejamos obrigados a empreender o estudo de sua vasta discografia.

Sendo assim, após analisarmos as sete canções-poemas, tomando seus temas e figuras como formações discursivas que remetem a formações ideológicas e, portanto, a uma isotopia temático-figurativa (e persuasiva) do enunciador da canção-poema (capítulo 2), buscaremos apreender o éthos da intérprete Maria Bethânia que, como já foi dito, será

\footnotetext{
${ }^{20}$ Nas palavras do próprio Greimas (2011, p. 171), “denominar-se-á enunciador o destinador implícito da enunciação (ou da 'comunicação'), distinguindo-o assim do narrador - como o 'eu', por exemplo - que é um actante obtido pelo procedimento da debreagem, e instalado explicitamente no discurso". Assim, em nossas análises, quando nos referirmos ao "eu" inscrito no texto-enunciado do poema ou da canção, nós o chamaremos de "narrador", para distingui-lo do sujeito enunciador, o "eu" da instância da enunciação que, enquanto fonte de valores, propõe ao enunciatário (leitor implícito) determinado contrato de veridicção.
} 
revelado a partir da visão de mundo desse sujeito, que está atrelada aos temas e figuras que os textos do corpus, no seu conjunto, permitem resgatar. Entretanto, isso não esgota as problemáticas envolvidas na análise. Ao contrário, ela está imbricada diretamente com mais três questões que também serão abordadas neste trabalho: o estilo, a autoria e os gêneros de discurso.

\subsection{Estilo}

A abordagem do estilo, no caso deste trabalho, é complexa, pois estamos lidando com gêneros do domínio literário. É preciso, portanto, definir a noção de estilo que assumimos aqui. Num primeiro momento, cabe ressaltar a distinção entre situação de comunicação e cena de enunciação. Isso porque tanto o éthos, como o estilo são desdobramentos da segunda categoria (e não da primeira). Para Maingueneau (2006, p. 250), enquanto a situação de comunicação relaciona-se com o exterior do texto (do ponto de vista sociológico), a cena de enunciação é considerada como um processamento interior ao discurso.

Assim, uma observação relevante sobre a questão do estilo é que este se relaciona com a recorrência de recursos usados pelo enunciador para persuadir o outro. Ao contrário da tradição aristotélica que deixou como legado uma orientação normativa sobre o estilo, o bom e o ruim, o adequado ou o inadequado, hoje, no âmbito dos estudos do discurso, interessa a descrição do homem como efeito de identidade na totalidade de textos. Nesse sentido, tal efeito é visto como uma maneira recorrente de tematização do mundo em que o enunciador apresenta-se diante dele. Em outras palavras, o estilo é caracterizado por meio de um modo recorrente de referencialização da enunciação no enunciado. Ressaltamos que a tematização não exclui as figuras projetadas nos enunciados. Como afirma Discini (2008, p. 43):

Em torno do núcleo figurativo, que supõe papéis recorrentes do sujeito, há variações temáticas e figurativas, para que a totalidade possa fundar-se numa configuração discursiva: um conjunto de temas e figuras que avalizam a imagem do sujeito enunciador como sistemas de crenças a respeito de si e do mundo. 
Ou seja, essa configuração discursiva remete à categoria de éthos na perspectiva teórica aqui adotada. Assim, a análise do éthos de Maria Bethânia também nos revelará o estilo assumido por ela nas canções-poemas, já que estamos levando em conta um conjunto de traços particulares reiterados nos textos.

Outro dado importante apontado por Fiorin (2008b, p. 104) é que, enquanto fato discursivo, o estilo é constituído heterogeneamente. Isso quer dizer que, ao se mostrar, o estilo mostra também seu avesso. Assim, na parte de análise destinada ao estilo, buscaremos evidenciar os traços recorrentes que Maria Bethânia imprime a suas canções-poemas, de modo a construir um estilo próprio, particular. Com isso, poderemos verificar se, de fato, como supomos, a hibridização de gêneros feita por ela gera um estilo autoral que, provavelmente, contradiz um estilo baseado apenas na forma como ela interpreta.

\subsection{Autor ou autoralidade}

Segundo Maingueneau (2010, p. 46), "todo texto implica certa autoralidade, e o modo de onde emerge o texto implica ele próprio essa forma de autoralidade". De um ponto de vista mais generalizado, constatamos que a problemática ligada à noção de autoria remonta aos séculos XVII e XVIII. Durante esse período, entende-se por autor o sujeito que responde por seus escritos, geralmente por uma questão de defesa contra a censura. Além disso, tal noção, nesse contexto, está associada ao direito jurídico das obras assinadas, o que gerou um debate acalorado sobre os dois núcleos de beneficiários (econômica e juridicamente falando) da obra: autores e editores.

No âmbito da Literatura, segundo Santos \& Oliveira (2001), até o século XIX, o autor ocupou o centro das atenções dos estudos literários. Instaurava-se, então, o biografismo, termo usado para caracterizar a investigação feita por muitos críticos literários dessa época. Eles acreditavam que a obra possuía uma verdade a ser desvendada por meio dos dados biográficos do autor. Pressupunha-se que havia uma maneira correta de ler determinada obra e que a vida do seu criador era o caminho adequado para essa leitura. Essa postura, como se pode ver, resulta da ideia de que a arte imita a vida. 
Essa corrente foi severamente criticada, a partir do século XX, pelas correntes de cunho formalista. Originaram-se, assim, estudos voltados para as formas dos textos, seus aspectos internos, excluindo-se os dados externos à obra. O texto ganha, assim, autonomia, e a intenção do autor passa a significar apenas no espaço textual. Com isso, a investigação do texto literário passa a ser feita por meio de suas características imanentes. O ponto mais importante dessa corrente é a radicalização dessas ideias com o decreto da "morte do autor". Tem-se, então, o imanentismo, em que o crítico literário busca a verdade do texto por meio de análises intrínsecas. Nesse caso, o autor passa a ser visto como um leitor qualquer, pois os sentidos do texto não precisam ter sido previstos ou desejados pelo autor; basta serem explicitados pela estrutura da obra.

Podemos depreender da exposição dessas duas correntes que o autor não era tratado, até então, como elemento discursivo. No âmbito da análise do discurso, Maingueneau (2010) chega mesmo a dizer que, embora Foucault tivesse apresentado na década de 1960, a questão $O$ que é um autor?, boa parte dos analistas do discurso, pelo menos na França, evitoua durante um bom tempo.

O pesquisador retoma, então, a noção de autoria e afirma que ela deveria ser uma questão central na análise do discurso, já que é indissociável da noção de texto. Na realidade, Maingueneau (2010, p. 26) considera-a como uma noção híbrida por ter implicações simultâneas tanto no texto como no mundo do qual o texto faz parte. Trata-se de uma instância enunciativa que possui atributos de um éthos e de alguns gêneros discursivos particulares, como os prefácios, mas que requer também um estatuto social, historicamente variável.

O teórico francês problematiza duas concepções de autor. A primeira implica, antes de tudo, um estatuto social. Trata-se de casos em que a palavra "autor" é acompanhada de um complemento de nome, como em "o autor do manual". Na outra acepção, a categoria "autor" é vista como um sujeito que deu a seu texto uma marca própria que a distingue, portanto, dos enunciados cotidianos. Assim, "os verdadeiros autores" seriam criadores originais. Após essa problematização, Maingueneau apresenta sua proposta: estudar a autoria com base nas imagens do autor, respeitando, portanto, a sua instância híbrida: a de enunciador do texto e a de indivíduo de carne e osso, o que se mostra compatível com a nova noção de éthos assumida por ele, em trabalhos mais recentes, que prevê uma vertente pré-discursiva ou prévia, ao lado de uma vertente propriamente discursiva. 
Em função disso, a autoria será estudada, neste trabalho, sob dois aspectos: a noção de éthos discursivo e o estatuto social do sujeito. Isso para que seja possível chegar a uma verificação das três dimensões de autor propostas pelo teórico francês, o que caracterizará, portanto, a posição de Maria Bethânia frente a suas canções-poemas: autor responsável, autor-ator ou auctor.

De acordo com Maingueneau (2010, p. 30), o autor-responsável é a "instância de um estatuto historicamente variável que responde por um texto", valendo para qualquer gênero de discurso. Já o autor-ator é a dimensão que, "organizando sua existência em torno da atividade de produção de textos, deve gerir uma trajetória, uma carreira". Por fim, auctor é o termo usado para designar o autor "enquanto correlato de uma obra", sendo que "uma obra, um Opus é, com efeito, tido como algo que 'exprime' a personalidade singular de seu autor" (MAINGUENEAU, 2010, p. 33).

Outro ponto relevante dos estudos de Maingueneau que converge com a questão da autoria, mais particularmente no tocante à noção de éthos, encontra-se no seguinte excerto: "Em literatura, porém, de maneira diferente do que ocorre em medicina, não existe diploma reconhecido que confere o direito à palavra. Para determinar quem tem o direito de enunciar, cada posição define em suas dimensões o que um autor legítimo é” (MAINGUENEAU, 2001, p. 77). Se entendermos que cada "posição" insere-se numa dada formação discursiva/ideológica, vemos que o enunciador da canção-poema pode realmente possuir dimensões autorais.

Assim, acreditamos que a análise do éthos da intérprete e, correlativamente, a do estilo das canções-poemas, direcionará este trabalho para a questão da autoria (ou da autoralidade, como prefere Maingueneau). Teremos, assim, percorrido uma parte da problematização da autoria das canções-poemas. Entretanto, como se viu, para que Maria Bethânia seja caracterizada como auctora faltará a dimensão social. Inicialmente, pensamos que o fato de a intérprete colocar-se entre a canção e o poema implica que "a terceira instância que consagra a qualidade de um texto" (como professores e críticos) possa não perceber o caráter de autoralidade que as canções-poemas suscitam. 


\subsection{Problemáticas voltadas para o estudo dos gêneros de discurso}

As três problemáticas contextualizadas nos itens anteriores podem ser vistas, na realidade, como partes de gêneros discursivos como a canção e o poema. Inclusive, o próprio fato de estarmos trabalhando com temas, por exemplo, já remete à tese bakhtiniana, segundo a qual o conteúdo temático, juntamente com o estilo (verbal) e a construção composicional, constitui um dos elementos característicos dos "tipos relativamente estáveis de enunciados", que são os gêneros de discurso (BAKHTIN, 2003, p. 262).

Na sequência de Bakhtin, que retomou e ampliou o estudo dos gêneros (para além daqueles que eram estudados na antiguidade clássica), vários autores propuseram-se a estudar e a ressignificar essa noção. No quadro da análise do discurso, Maingueneau define os gêneros do discurso como "dispositivos de comunicação sócio-historicamente condicionados, que estão sempre mudando e aos quais podem ser facilmente aplicadas metáforas como 'contrato', 'ritual' e 'jogo'” (MAINGUENEAU, 2010, p. 130).

O estudo da hibridização dos gêneros poema e canção num mesmo espaço textual encontra um lugar relevante no quadro teórico-metodológico de Maingueneau por duas razões. A primeira é pelo fato de que a canção-poema parece problematizar a seguinte hipótese: "a renovação, entretanto, não tem por função contestar a cena genérica: salvo exceções, um cantor de música popular não põe em questão o gênero canção popular" (MAINGUENEAU, 2004, p. 51). Nesse caso, teríamos que verificar se os novos e mais complexos efeitos de sentido que surgem da hibridização do poema e da canção deixam suas cenas genéricas intactas.

Em segundo lugar, a relação entre cena genérica e cena englobante, ambas propostas pelo autor, juntamente com a noção de cenografia, é bastante significativa para o presente trabalho. A cena genérica diz respeito ao contrato associado a um dado gênero do discurso. Já a cena englobante é atribuída ao estatuto pragmático do discurso, ou seja, ao tipo de discurso (literário, filosófico etc.). Por fim, a cenografia constitui a validação pressuposta na cena de fala, sendo, pois, uma construção do próprio texto.

Como vimos em 1.2., os gêneros canção e poema diferenciam-se, entre outros aspectos, pelos papéis sociais relacionados a um e à outra. Na canção, tem-se um enunciador popular, enquanto no poema, um enunciador erudito. Além disso, esses gêneros também se diferenciam pelas circunstâncias. O poema exige a individualização do sujeito, portanto, um lugar e um tempo que favoreçam o seu isolamento; já a canção não exige, necessariamente, tal 
circunstância. Esses aspectos, entre outros, nos levaram a afirmar, anteriormente, que o poema pertenceria à cena englobante literária, enquanto a canção se enquadraria na literatura de massa ou na "paraliteratura", um enquadramento que pode ser mais complicado (e passível de críticas) do que parece à primeira vista ${ }^{21}$. A questão que se coloca, então, é a seguinte: no caso da canção-poema, como fica a cena englobante? Nossa hipótese é a de que uma construção desse tipo ultrapassaria, de certa forma, as diferenças apontadas, parecendo agrupar esses dois gêneros numa espécie de cena englobante única, que neutraliza a bipolarização entre literatura e paraliteratura (ou literatura de massa).

Uma outra questão relevante no âmbito dos gêneros é a própria noção de hibridização, sobretudo se levarmos em conta que esse fenômeno vem-se constituindo numa prática frequente, na pós-modernidade, de modo a criar novos efeitos de sentido para sensibilizar e surpreender um leitor cada vez mais exigente e globalizado, como defende Chaves (2010), no âmbito da publicidade. Essa prática discursiva, que assume nomes distintos de acordo com o ponto de vista assumido pelo pesquisador, vem sendo trabalhada por vários autores no quadro da análise do discurso, entre os quais Lara (2010) e Chaves (2010), e também no âmbito da linguística textual, como é o caso de Marcuschi (2008) e Miranda (2007).

Para nossa problematização sobre o assunto, vamos considerar apenas as posições de Lara (2010) e Miranda (2007). Para a primeira, o fenômeno que ela chama de "transgressão" ocorre "quando um dado gênero (transgressor) assume a função de outro (o transgredido), emprestando-lhe, ao mesmo tempo sua forma" (LARA, 2010, p. 8). Já Miranda (2007) fala de "intertextualização". Segundo ela, "um dado texto que se inscreve em um gênero textual determinado, recorre à intertextualização quando introduz traços que se associam a outros gêneros diferentes do próprio" (MIRANDA, 2007, p. 1047). Vemos, pois, que a proposta de Miranda é mais ampla que a de Lara, pois aquela afirma que a presença de alguns traços de um dado gênero no interior do outro já permite falar em hibridização/intertextualização.

Não há dúvida de que Maria Bethânia articula o poema e a canção. Entretanto, a forma como essa articulação - ou hibridização - é feita não se enquadra em estudos como os que foram aqui mencionados. Não podemos, por exemplo, classificá-lo como transgressão, no sentido atribuído por Lara (2010), por pelo menos dois motivos. Nas canções-poemas, não

\footnotetext{
${ }^{21}$ Essa discussão será retomada e aprofundada no Capítulo 3.
} 
parece haver uma distinção clara entre a função ${ }^{22}$ de um poema e a função de uma canção. Quanto à questão da forma, não podemos afirmar nada sem uma análise que leve em conta também o plano de expressão dos textos, o que, por razões de tempo e espaço, não faremos aqui. Também não encontramos razão para enquadrar o procedimento adotado por Bethânia na proposta de Miranda (2007), porque não há uma recorrência de traços próprios, por exemplo, do poema na canção ou vice- versa. Esses dois gêneros se articulam nos textos sem que os elementos (que os constituem enquanto gêneros de discurso) de um e de outro se misturem, de fato, como ficará mais claro no capítulo destinado às análises.

Assim, o que procuraremos fazer em relação a essa problemática é evidenciar que os novos e mais complexos efeitos de sentidos obtidos pela hibridização dos gêneros canção e poema nos textos de Maria Bethânia parece requerer outros estudos para uma possível (re)classificação desse fenômeno, já que ele assume uma configuração única, distinta das abordagens citadas mais acima. Em 3.4., retomaremos essa discussão.

Um outro dado a ser problematizado é o fato de que os traços distintivos referentes às categorias de éthos, autoria e estilo parecem ser menos relevantes para a determinação de gêneros em outras esferas sociais/discursivas do que na literatura. Nesse domínio, tais traços parecem assumir uma importância capital tanto para a classificação dos gêneros quanto para a questão da hibridização. Ora, o fato de a intérprete escolher determinados autores (e não outros) de um determinado gênero - o poema -, por exemplo, aponta para uma proposta em que não se trata apenas de inserir novos temas ou novas figuras na canção, mas também, e, sobretudo, de contrastar estilos, originando outro(s).

Para encerrar este capítulo, em que apresentamos as questões metodológicas e teóricas que sustentam o presente trabalho, proporemos, a seguir, uma síntese de nossos objetivos, incluindo a ordem em que as questões aqui levantadas serão abordadas nos próximos capítulos.

\footnotetext{
${ }^{22}$ Aliás, sabemos da importância do conceito de função (ou finalidade) para a análise dos gêneros discursivos. Entretanto, quando entramos no campo discursivo da literatura, a operacionalização de tal conceito parece não ter a mesma propriedade que possui em gêneros de outras esferas sociais. Daí a importância de incentivarmos investigações voltadas para a operacionalidade desse conceito em gêneros da esfera da literatura. Cabe-nos perguntar: como separamos, em termos de função, um poema de uma canção? E, por extensão, como distinguimos esses gêneros do romance, do conto, do teatro etc.?
} 


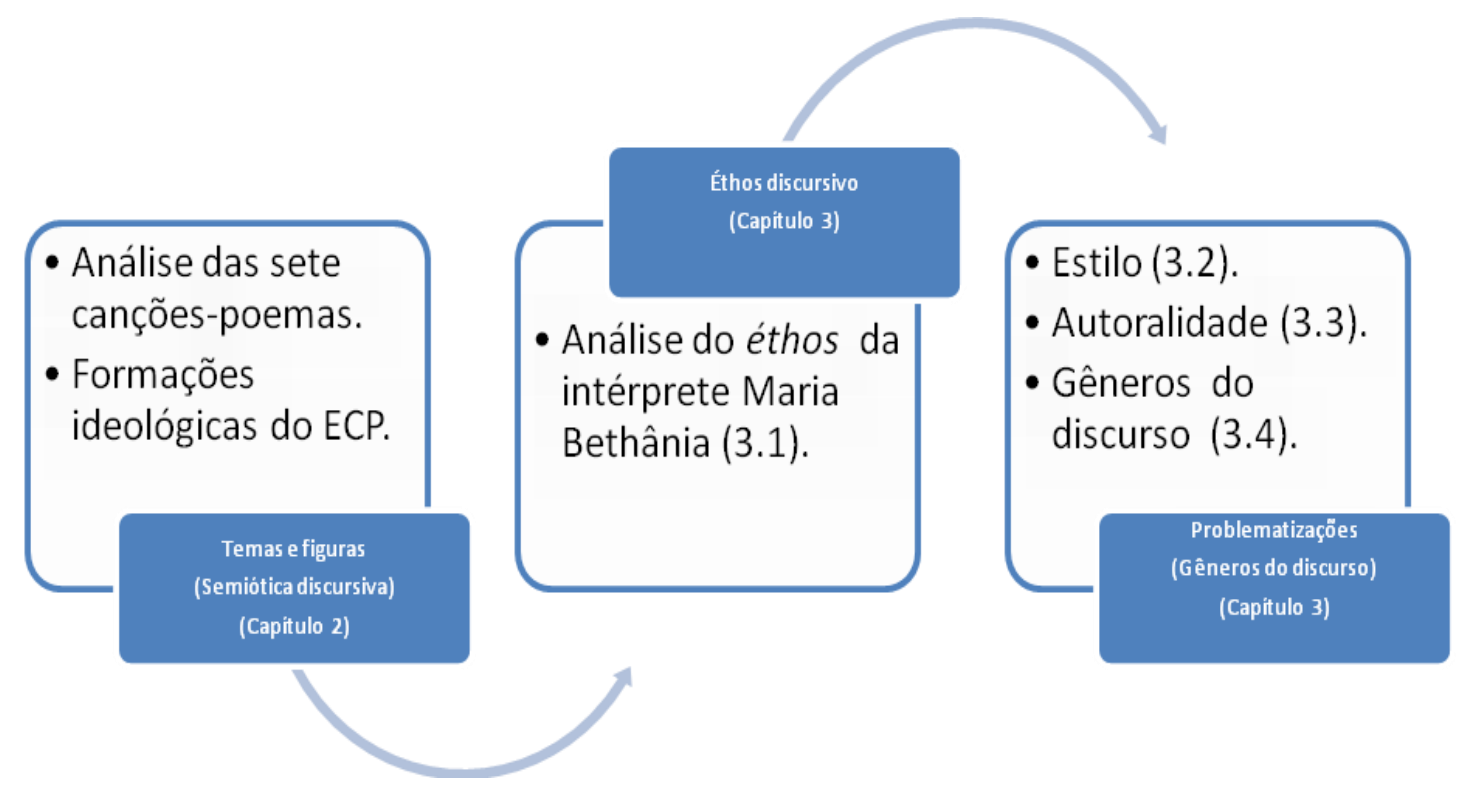

GRÁFICO 1 - Síntese dos pressupostos teórico-metodológicos 


\title{
CAPÍTULO 2: ANÁLISE DOS TEMAS E FIGURAS NAS CANÇÕES-POEMAS
}

\author{
"Umas figuras insiro em contos, ou subtítulos de livros, e assino com o \\ meu nome o que delas dizem; outras projeto em absoluto e não assino \\ senão com o dizer que as fiz”. (FERNANDO PESSOA, 2011, p.11)
}

Apresentamos, a seguir, a análise dos temas e figuras dos textos do corpus. Lembramos que temas são investimentos semânticos, de natureza puramente conceptual, ou seja, são categorias que organizam ou ordenam os elementos do mundo natural: elegância, vergonha, raciocinar, calcular, orgulhoso etc., enquanto figuras são termos que remetem a algo do mundo natural: árvore, vagalume, sol, correr, brincar, vermelho, quente etc., ou seja, são conteúdos de qualquer língua natural (qualquer sistema de representação) que têm um correspondente perceptível no mundo natural (ou construído como tal) (FIORIN, 1989, p. 65). No caso de textos predominantemente figurativos, como é o caso dos poemas e das letras das canções aqui examinados, cabe ao analista apreender os temas que "iluminam" as figuras ${ }^{23}$.

Com o intuito de conseguir um grau de clareza satisfatório, separamos em diferentes itens as canções-poemas analisadas. Nesse caso, cada subtítulo se constitui da justaposição dos nomes do poema e da canção que serão examinados naquela seção. Além disso, optamos por estruturar cada análise da seguinte forma: primeiramente, analisaremos o poema e a canção como gêneros independentes, inclusive, procurando, sempre que possível, citar os textos de acordo com a forma como foram individualmente publicados. Posteriormente, investigaremos a hibridização canção-poema feita por Maria Bethânia, buscando destacar, em cada caso, os novos efeitos de sentido obtidos nesse processo. Outro aspecto da organização da análise das canções-poemas é a ordem. Esta é condizente com os quadros propostos em 1.1. O objetivo dessas análises é desvelar, por meio dos percursos temático-figurativos elencados, as formações discursivas e ideológicas em que se situa a enunciadora da canção-poema (ECP), o que nos fornecerá subsídios teórico-analíticos para prosseguir com nossa investigação no capítulo 3.

\footnotetext{
${ }^{23}$ Por essa razão, para falar do encadeamento de figuras do/no texto, usaremos, preferencialmente, o termo "percurso temático-figurativo" para lembrar que as figuras só ganham sentido quando se apreende o tema que subjaz a elas.
} 
Resta, finalmente, dizer que não estamos fazendo "a" leitura dos textos, mas "uma" leitura, entre outras possíveis, já que os objetos analisados permanecem abertos para novas investigações, que podem, portanto, depreender deles sentidos outros não contemplados aqui. Não pretendemos também fazer uma análise exaustiva de cada texto, mas apenas apontar os temas e figuras, reunidos em percursos, que nos parecem mais relevantes para a compreensão do contrato que se estabelece entre enunciador e enunciatário em cada caso, com destaque para o enunciador do terceiro texto (canção-poema), em consonância com os objetivos apontados anteriormente.

\subsection{Eros e Psique / Tigresa}

A primeira canção-poema que analisaremos é Eros e Psique / Tigresa do álbum de estúdio Pássaro da manhã (BETHÂNIA, 1977). Ressaltamos que se trata da primeira vez que apareceu em CD de estúdio o fenômeno canção-poema na obra da intérprete.

\subsubsection{Análise do poema Eros e Psique}

Esse poema é de autoria de Fernando Pessoa, ortônimo. Fernando Antônio Nogueira Pessoa nasceu em 13 de junho de 1888, em Lisboa. Foi admitido na Universidade do Cabo em 1903, mas, após um ano, deixou a universidade. Foi nesse período que o poeta português criou seus vários poetas fictícios. Em 1905, chegou a inscrever-se na Faculdade de Letras, mas quase não frequentava o curso, do qual desistiu, definitivamente, com a morte da irmã Maria Clara. Em 1908, exerceu a profissão de "correspondente de língua estrangeira" e tradutor que desempenharia até o fim de sua vida. Em 1912, ocorreu sua estreia na literatura com a publicação de artigos na revista A Águia e, em 1914, o poeta criou seus três principais heterônimos: Alberto Caeiro, Ricardo Reis e Álvaro de Campos. Morreu no dia 30 de novembro de 1935 (ver PESSOA, 2011, p. 7-20). 
Esclarecemos que Maria Bethânia citou o poema Eros e Psique por inteiro, eliminando apenas a epígrafe. Reproduzimos abaixo o poema, de acordo com sua forma de publicação no livro Ficções do interlúdio (PESSOA, 1998).

\section{EROS E PSIQUE}

E assim vedes, meu irmão, que as verdades que vos foram dadas no Grau de Neófito, e aquelas que vos foram dadas no Grau de Adepto Menor, são, ainda que opostas, a mesma verdade.

Do ritual do Grau de Mestre do Átrio na Ordem Templária de Portugal

Conta a lenda que dormia Uma Princesa encantada

A quem só despertaria Um Infante, que viria De além do muro da estrada.

Ele tinha que, tentado, Vencer o mal e o bem, Antes que, já libertado, Deixasse o caminho errado Por o que à Princesa vem.

A Princesa Adormecida, Se espera, dormindo espera, Sonha em morte a sua vida, E orna-lhe a fronte esquecida, Verde, uma grinalda de hera.

Longe o Infante, esforçado, Sem saber que intuito tem, Rompe o caminho fadado, Ele dela é ignorado,

Ela para ele é ninguém.

Mas cada um cumpre o Destino Ela dormindo encantada, Ele buscando-a sem tino Pelo processo divino Que faz existir a estrada.

E, se bem que seja obscuro Tudo pela estrada fora, E falso, ele vem seguro, E vencendo estrada e muro, Chega onde em sono ela mora, $\mathrm{E}$, inda tonto do que houvera, À cabeça, em maresia, 
Ergue a mão, e encontra hera,

E vê que ele mesmo era

A Princesa que dormia.

(PESSOA, 1914-1935/1998, p. 103-104, grifos do autor).

Iniciando a análise do poema pela epígrafe, encontramos uma reflexão que remete ao tema da verdade, mostrada como algo irredutível à gradação (ela independe do grau de conhecimento do sujeito: Grau de Neófito ou Grau de Adepto Menor). O que existe, pois, é uma verdade única e não progressiva.

Já no poema propriamente dito, apreendemos, em primeiro lugar, o tema da dominação masculina. O homem é valorizado como um ser ativo, ao contrário da mulher, que é passiva, o que está subjacente à oposição entre os percursos figurativos: "dormia uma princesa", "sonha em morte a sua vida", "dormindo", "em sono ela mora", de um lado, e "O infante, esforçado", "rompe o caminho", "busca-a", "vencendo estrada e muro", de outro. Aqui cabe, inclusive, uma pequena alusão ao mito de Eros e Psique que nomeia o poema. Nele, é Eros, filho de Afrodite, que toma atitudes. Ele desobedece à mãe ao apaixonar-se por Psique. Também é ele que implora a Zeus que apazigue a ira de Afrodite e ratifique seu casamento com Psique ${ }^{24}$. O tema da passividade feminina, no poema, é "atravessado" por outro: o tema da vaidade, recuperável em figuras como "orna-lhe" e "grinalda", tema que também se ancora no mito grego, pois Psique é descrita como uma mulher muito bonita.

Há ainda o percurso figurativo da predestinação para o amor, já que homem e mulher comportam-se de acordo com o "destino", com o "processo divino". No caso desse poema, a predestinação é um tema relevante, pois ainda que o infante tenha a impressão de que tudo era falso ("obscuro", "falso"), ele continua seguindo o seu caminho de forma inexorável, como se não pudesse deixar de fazê-lo.

Em terceiro lugar, apreendemos um percurso que poderíamos denominar percurso do "desencontro amoroso", já que o homem descobre, enfim, ser ele mesmo a princesa que dormia. Mas é exatamente essa espécie de desencontro amoroso que lhe permite, por meio do encontro consigo mesmo, chegar à razão, ou ainda, à autodescoberta, o que remete à reflexão da epígrafe sobre a verdade, fechando o ciclo do poema. Por último, Eros e Psique são figuras que nos remetem ao tema da presença da mitologia grega no gênero poema, o que, aliás, orienta o estilo de determinados poetas.

\footnotetext{
24 Ainda que na lenda Psique adormeça por obra de Perséfone (como castigo por ter sido movida pela curiosidade) e Eros volte para buscá-la por amor, acreditamos que tais fatos não descaracterizam o tema da passividade feminina em oposição ao da ação masculina. Até porque, a referência à lenda pode ser vista como opção de leitura, enriquecedora, mas não obrigatória ou de interpretação unívoca.
} 
Apreendemos esses conjuntos de temas e figuras como formações discursivas que remetem a determinações ideológicas, de acordo com o que propõe Fiorin (2007). Assim, a "visão de mundo" do enunciador do poema (EP) é a de descrença na busca do amor figurativizado por uma mulher passiva que espera ser encontrada por um homem corajoso. No entanto, esse fato não neutraliza a formação ideológica machista; ao contrário, reafirma-a, porque a ação filosófica da descoberta dessa espécie de "ateísmo" amoroso é feita pela figura masculina, enquanto a figura feminina continua passiva. Esses são, em suma, os elementos que regem um parecer de sentido que julgamos relevante para o poema apresentado.

\subsubsection{Análise da canção Tigresa}

Passemos agora à análise da canção Tigresa, de Caetano Veloso. Nascido em 07 de agosto de 1942, em Santo Amaro da Purificação, na Bahia, Caetano Emmanuel Vianna Telles Veloso é um dos principais compositores e cantores brasileiros. Seu primeiro LP, Domingo, foi gravado em 1967. Em 1968, lançou o LP Tropicália, juntamente com outros artistas, dando início a um importante movimento cultural: o Tropicalismo. Seu último CD, Abraçaço, foi lançado em 2012. Sobre a canção Tigresa, que transcrevemos abaixo, ela foi lançada pelo compositor baiano no seu disco Bicho (VELOSO, 1977) ${ }^{25}$.

\section{Tigresa}

Uma tigresa de unhas negras

e íris cor de mel

Uma mulher, uma beleza que me aconteceu

Esfregando a pele de ouro marrom

Do seu corpo contra o meu

Me falou que o mal é bom e o bem cruel

Enquanto os pelos dessa deusa

tremem ao vento ateu

Ela me conta sem certeza tudo o que viveu

Que gostava de política em mil novecentos

e sessenta e seis

E hoje dança no Frenetic Dancing Days

Ela me conta que era atriz e trabalhou no Hair

Com alguns homens foi feliz,

Com outros foi mulher

Que tem muito ódio no coração, que tem dado muito amor

\footnotetext{
${ }^{25}$ Dados disponíveis em: www.caetanoveloso.com.br. Acesso em: 26 jan. 2013.
} 
E espalhado muito prazer e muita dor

Mas ela, ao mesmo tempo,

diz que tudo vai mudar,

Ela vai ser o que quis, inventando um lugar

Onde a gente e a natureza feliz,

Vivam sempre em comunhão

$\mathrm{E}$ a tigresa possa mais do que o leão.

As garras da felina me marcaram o coração

Mas as besteiras de menina,

que ela disse, não

E eu corri pra o violão num lamento

E a manhã nasceu azul

Como é bom poder tocar um instrumento

(VELOSO, 1977, faixa 7)

Há um percurso temático-figurativo nessa canção que podemos designar como "conquista feminina ativa". Isso porque a ação de conquistar é figurativizada nas ações de "uma tigresa de unhas negras e íris cor de mel". Tal percurso pode ser visto, por exemplo, em figuras como "esfregando a pele de ouro marrom do seu corpo contra o meu" e "ela me conta, sem certeza, tudo que viveu". Sendo assim, ao contrário do primeiro texto, aqui sobressai um discurso de valorização da mulher, enquanto um ser que age, embora o excerto "onde a gente e a natureza feliz, / vivam sempre em comunhão/ E a tigresa possa mais do que o leão" demonstre que esse discurso feminista ainda precisa conquistar outros espaços. Isso se justifica pelo fato de o poder feminino estar, na canção, mais relacionado ao campo das relações amorosas.

Isso, no entanto, não quer dizer desprestígio. Talvez possa até ser mais relevante do que outras conquistas, como as intelectuais e as relacionadas ao trabalho, já que a tigresa "gostava de política", “dança no Frenetic Dancing Days"; “era atriz e trabalhou no Hair". À conquista amorosa, pode-se acrescentar o tema da liberdade sexual: "com alguns homens foi feliz, com outros foi mulher”. Ressalte-se ainda que é a mulher que toma a iniciativa na relação amorosa, esfregando seu corpo contra o do homem e falando de sua vida pregressa, embora essa última questão não receba valorização tão positiva quanto a perfórmance sexual da tigresa: o "parceiro" não acredita nela quando o que está em jogo é o que ela diz, qualificando-o de "besteiras de menina".

Apesar dessa ressalva, é ela que "marca o coração" do homem que, abandonado no final (ao que parece), não vê outra alternativa senão consolar-se com seu violão. De toda forma, o que é relevante para a composição de um quadro de produção de sentidos é perceber que o enunciador da canção (EC) pode ser visto, sobretudo, como defensor de um mundo feminista, ainda que aqui isso esteja mais ligado à liberação sexual da mulher. 


\subsubsection{Análise de Eros e Psique / Tigresa: um terceiro texto}

Apesar de Maria Bethânia ter tomado a canção de Caetano Veloso na íntegra e ter excluído do poema de Fernando Pessoa apenas a epígrafe, como foi dito, optamos por reproduzir a canção-poema tal como ela foi encontrada no encarte do CD da intérprete. Além disso, também destacamos o fato de o CD Pássaro da Manhã ter sido lançado em 1977, coincidentemente ou não, no mesmo ano em que o compositor Caetano Veloso havia lançado a canção Tigresa.

\section{Texto de Fernando Pessoa}

Conta a lenda que dormia

Uma Princesa encantada

A quem só despertaria

Um Infante, que viria

De além do muro da estrada.

Ele tinha que, tentado, Vencer o mal e o bem, Antes que, já libertado, Deixasse o caminho errado Por o que à Princesa vem.

A Princesa Adormecida, Se espera, dormindo espera, Sonha em morte a sua vida, E orna-lhe a fronte esquecida, Verde, uma grinalda de hera.

Longe o Infante, esforçado, Sem saber que intuito tem, Rompe o caminho fadado, Ele dela é ignorado,

Ela para ele é ninguém.

Mas cada um cumpre o Destino

Ela dormindo encantada,

Ele buscando-a sem tino

Pelo processo divino

Que faz existir a estrada.

E, se bem que seja obscuro

Tudo pela estrada fora, E falso, ele vem seguro, E vencendo estrada e muro, Chega onde em sono ela mora, 
$\mathrm{E}$, inda tonto do que houvera,

À cabeça, em maresia,

Ergue a mão, e encontra hera,

$E$ vê que ele mesmo era

A Princesa que dormia.

\section{Tigresa}

Uma tigresa de unhas negras

e íris cor de mel

Uma mulher, uma beleza que me aconteceu

Esfregando a pele de ouro marrom

Do seu corpo contra o meu

Me falou que o mal é bom e o bem cruel

Enquanto os pelos dessa deusa

tremem ao vento ateu

Ela me conta sem certeza tudo o que viveu

Que gostava de política em mil novecentos

e sessenta e seis

E hoje dança no Frenetic Dancing Days

Ela me conta que era atriz e trabalhou no Hair

Com alguns homens foi feliz,

Com outros foi mulher

Que tem muito ódio no coração,

que tem dado muito amor

E espalhado muito prazer e muita dor

Mas ela, ao mesmo tempo,

diz que tudo vai mudar,

Ela vai ser o que quis, inventando um lugar

Onde a gente e a natureza feliz,

Vivam sempre em comunhão

$\mathrm{E}$ a tigresa possa mais do que o leão.

As garras da felina me marcaram o coração

Mas as besteiras de menina,

que ela disse, não

E eu corri pra o violão num lamento

E a manhã nasceu azul

Como é bom poder tocar um instrumento

(BETHÂNIA, 1977, faixas, 1-2)

A hibridização acima, que junta dois textos de gêneros diferentes (canção e poema), mais do que uma mera justaposição, revela-nos o reenquadramento das determinações ideológicas dos textos que foram analisados de forma independente. Acreditamos que há uma sobreposição do enunciador/intérprete da canção-poema em relação aos outros dois enunciadores (EP e EC), tomados isoladamente. A nova configuração passa, assim, a abarcar os dois textos, formando um terceiro texto, com outros (novos) efeitos de sentido. Desse modo, a ideia de descoberta de si mesmo(a) presente no poema passará a ser um valor também para a figura feminina, que era completamente passiva no primeiro texto. Assim, temos o engendramento do tema da igualdade na busca pelo amor, mas também uma 
reivindicação de igualdade entre os sexos, o que é percebido apenas no discurso do enunciador da canção-poema (ECP).

Sendo assim, outros temas e figuras passam a fazer parte do fazer persuasivo do enunciador dessa canção-poema. Em "texto de Fernando Pessoa" (que é enunciado por Bethânia) e "infante" podemos apreender uma referência a Portugal ${ }^{26}$. Com isso, a passividade de Psique pode ser vista como um comportamento feminino criticado, por exemplo, em poemas de Maria Teresa Horta, que, de acordo com Oliveira (2005), foi uma poetisa marcante na literatura portuguesa da segunda metade do século XX: antes, durante e depois da Revolução dos Cravos. A autora analisa alguns poemas do livro Mulheres de Abril, de Horta, que foi publicado em 1977, apontando temas como a denúncia da mulher como propriedade do homem, ou seja, o caráter de passividade e submissão femininas.

Cabe também outra observação. Como a análise intradiscursiva nos direcionou a Portugal, lembramos que "os 48 anos de fascismo, juntamente com sua aliança religiosa à igreja católica e a guerra colonial moldaram uma sociedade portuguesa conservadora impedindo-a de acompanhar as transformações ocorridas no restante do mundo", o que contribuiu para um desenvolvimento tardio do feminismo em Portugal (AZAMBUJA; NOGUEIRA; SAAVEDRA, 2007, p.213). Tal ocorrência é ainda mais significativa quando levamos em conta a análise do contexto histórico que envolve esses textos. O poema de Fernando Pessoa foi publicado em 1934, época em que, como se viu, as questões feministas não eram manifestadas. Já a canção e a canção-poema foram lançadas, no Brasil, ambas em 1977, o que implica a presença dominante de uma formação ideológica feminista.

Portanto, temos na canção-poema a inscrição de valores no discurso do ECP que ultrapassam os valores defendidos pelos EP e EC, individualmente. Nesse último texto, temos, na realidade, uma ênfase na gradual defesa dos direitos da mulher. Esta passa de passiva (acionada pelo homem) a detentora de liberdade sexual (agora é ela que aciona o homem), mas, quando se defende o lugar da mulher como aquele onde "a gente e a natureza feliz,/ vivam sempre em comunhão/ E a tigresa possa mais do que o leão”, percebemos que ainda resta à mulher um longo caminho para se impor, de fato, numa sociedade como a nossa, o que coincide com os movimentos feministas ${ }^{27}$, que defendem os direitos privados e públicos da mulher. Ou seja, na canção-poema, as mulheres (Psique, Tigresa) não apenas deixam de

\footnotetext{
${ }^{26}$ Mobilizamos aqui informações do contexto mais amplo (sócio-histótico-ideológico), conforme foi explicitado na nota 17. Esse procedimento se repetirá nas demais análises, como se verá.

${ }^{27}$ Usamos a expressão "movimentos feministas" de maneira mais abrangente. Assim, tal conceito não deve ser entendido como algo ligado a uma instituição. Pelo contrário, trata-se de uma tomada de posição em que transparece o discurso das conquistas e da valorização da mulher.
} 
ser passivas, mas encontram-se providas de razão. Essa razão, no entanto, parece não estar delimitada à descoberta de si (e talvez, por isso, Bethânia suprima a epígrafe do poema de Pessoa, colocando a verdade em segundo plano). Em função disso, no discurso do ECP, os direitos das mulheres podem ser vistos com maior amplitude, envolvendo vários aspectos de suas vidas, para além da questão amorosa apenas.

\subsection{O poeta come amendoim / Canto do Pajé}

Essa canção-poema fez parte do repertório do disco Maria Bethânia 25 anos (BETHÂNIA, 1990/2006), gravado em estúdio no ano de 1990. De acordo com Faour, no texto de apresentação de relançamento desse trabalho, o repertório do disco evocava canções de distintas fases da Música Popular Brasileira (MPB). Nesse CD, encontrava-se a mistura de influências do branco, do negro e do índio no cancioneiro popular. O primeiro exemplo dessa mescla era a canção Canto do Pajé, que havia ganhado destaque nas audições de canto orfeônico. Isso porque ela havia circulado bastante nas escolas de ensino médio no Brasil, graças a Villa Lobos, que valorizava nossa canção ancestral indígena.

\subsubsection{Análise do poema $O$ poeta come amendoim}

O poema citado por Maria Bethânia, que é datado de 1924 e publicado em 1927, pertencia ao livro Clan do jabuti. Seu autor, Mário de Andrade, o dedicou ao poeta mineiro Carlos Drummond de Andrade. Vejamos, primeiramente, alguns dados do autor. Mário Raul de Moraes Andrade nasceu em 09 de outubro de 1893. Escreveu seu primeiro livro, Há uma gota de sangue em cada poema, sob o pseudônimo de Mário Sabral. Foi um dos principais nomes da Semana de Arte Moderna de 1922 e publicou a primeira obra tipicamente modernista: Paulicéia desvairada. Em 1926, escreveu Macunaíma e continuou escrevendo poesia. Morreu em 25 de fevereiro de 1945 (OLIVEIRA, 2000, p. 282). Segue o poema: 


\section{O POETA COME AMENDOIM ${ }^{28}$}

Noites pesadas de cheiros e calores amontoados...

Foi o Sol que por todo o sítio imenso do Brasil

Andou marcando de moreno os brasileiros.

Estou pensando nos tempos de antes de eu nascer...

A noite era pra descansar. As gargalhadas brancas dos mulatos ...

Silencio! O imperador medita os seus versinhos.

Os Caramurús conspiram na sombra das mangueiras ovais.

Só o murmurejo dos cre'm-deus-padres irmanava os homens de meu país...

Duma feita os canhamboras perceberam que não tinha mais escravos,

Por causa disso muita virgem-do-rosario se perdeu...

Porém o desastre verdadeiro foi embonecar esta República temporã.

A gente inda não sabia se governar...

Progredir, progredimos um tiquinho

Que o progresso também é uma fatalidade...

Será o que Nosso Senhor quiser!...

Estou com desejos de desastres...

Com desejos do Amazonas e dos ventos muriçocas

Se encostando na cangerana dos batentes...

Tenho desejos de violas e solidões sem sentido

Tenho desejos de gemer e de morrer.

Brasil...

Mastigado na gostosura quente do amendoim...

Falado numa língua curumim

De palavras incertas num remeleixo melado melancolico...

Saem lentas frescas trituradas pelos meus dentes bons...

Molham meus beiços que dão beijos alastrados

E depois semitoam sem malícia as rezas bem nascidas...

Brasil amado não porque seja minha patria,

Patria é acaso de migrações e do pão-nosso onde Deus der...

Brasil que eu amo porque é o ritmo do meu braço aventuroso,

O gôsto dos meus descansos,

$\mathrm{O}$ balanço das minhas cantigas amores e dansas.

Brasil que eu sou porque é a minha expressão muito engraçada,

Porque é o meu sentimento muito pachorrento,

Porque é o meu geito de ganhar dinheiro, de comer e de dormir

(ANDRADE, 1955, p.157-158).

\footnotetext{
${ }^{28}$ Ao reproduzir o poema, optamos por manter sua ortografia original.
} 
De acordo com Faraco e Moura (1990, p. 203), Mario de Andrade escreveu a obra Clã do jabuti (1927), "utilizando material do folclore, dos costumes e da linguagem de diferentes regiões do país" para apreender "a diversidade cultural do Brasil". Esse tema maior - a diversidade cultural brasileira - de fato, pode ser apreendido, no poema, por meio de um percurso que traz figuras, como: “imperador", "Caramurús", "Cre'm-deus-padres", "canhamboras".

Entretanto, em $O$ poeta come amendoim, há um tema que se destaca mais: o nacionalismo ou patriotismo, porque sua caracterização foge aos padrões comuns. Para expor seu amor pelo Brasil, o EP põe, inicialmente, na boca do narrador ${ }^{29}$, a decomposição de temas relacionados à "brasilidade": a cor dos brasileiros em decorrência do clima tropical; as peripécias da história do Brasil, por meio da figura "Caramurús" (fazendo referência à conquista desse país pelos portugueses); a passividade do império; a libertação repentina dos escravos; a prematura proclamação da República; o progresso como algo inevitável e não como uma conquista. Nesse sentido, o nacionalismo que é projetado no poema não está restrito a determinados fatos históricos: por exemplo, o reconhecimento da figura do índio, como foi feito no Romantismo brasileiro, ou mesmo fatos como a defesa de um regime político (o Império ou a República), o que pode ser visto, na literatura, com o personagem Quaresma, de Lima Barreto, conforme mostra o trecho abaixo:

\footnotetext{
Quaresma estava longe de pensar nisso tudo; ele com muitos homens honestos e sinceros do tempo foram tomados pelo entusiasmo contagioso que Floriano conseguira despertar. Pensava na grande obra que o Destino reservava àquela figura plácida e triste; na reforma radical que ele ia levar ao organismo aniquilado da pátria (BARRETO, 1994 p.126).
}

Ao contrário disso, para nos aproximarmos da acepção de nacionalismo projetada no texto pelo EP, precisamos atrelar a diversidade a mais uma figura que possui traços de "brasilidade": o amendoim, uma planta anual, típica do Brasil. EP mostra, então, seu "patriotismo" (seu amor à pátria) por meio de todos aqueles elementos que possuem traços de "brasilidade" mastigados "na gostosura quente do amendoim". Ou seja, é a decomposição desses elementos que revelará o amor de EP à pátria, o que confere ao nacionalismo do poema um caráter de algo “(re)construído”, que merece, portanto, uma redefinição. Isso é explicitado na última estrofe, na qual esse amor à pátria é justificado por vários traços que não se

\footnotetext{
${ }^{29}$ Lembramos que o narrador constitui o "eu" inscrito no texto-enunciado, distinguindo-se, pois, do enunciador (ou autor implícito) que, como tal, remete à instância da enunciação (considerada como ato implícito de produção do enunciado e logicamente pressuposta pela própria existência do dito), como explica Fiorin (2003, p. 163). Nunca é demais lembrar que o enunciador é a fonte dos valores projetados no texto que são, via de regra, assumidos/ditos pelo narrador.
} 
relacionam, de forma imediata, com os anteriores. Aqui temos os temas da alegria, do amor, enfim, do modo de vida do brasileiro nas figuras: "o ritmo do braço aventuroso", "o gosto dos meus descansos", "o balanço das minhas cantigas, amores e danças", "meu jeito de ganhar dinheiro, de comer e de dormir”. Assim, é por ser o que é que o EP revela e justifica (pela voz do narrador) seu amor à pátria.

Outro dado em que gostaríamos de nos deter é o fato de o poema ser dedicado a Carlos Drummond de Andrade. Dessa forma, o EP reconstrói a nacionalidade brasileira, por meio dos percursos temático-figurativos expostos anteriormente, e, ao mesmo tempo, prevê um enunciatário que perceba que os valores presentes no poema encontram-se orientados para certo tipo de avaliação/aceitação do poeta mineiro.

Salientamos que a intérprete Maria Bethânia não cita o poema na íntegra nessa ocasião $^{30}$. Ela faz o seguinte recorte: escolhe as duas primeiras estrofes. Optamos, no entanto, por reproduzir e analisar o poema inteiro para mostrar que há uma estratégia de citação, que se encontra na disposição dos elementos da organização textual. No pequeno trecho, retirado do poema e colocado na introdução da canção-poema, subjazem temas e figuras que não podem ser apreendidos nas outras partes do texto. Nele, a análise de temas e figuras se restringe à reflexão sobre a questão da cor da pele ${ }^{31}$ dos brasileiros, antes de o enunciador do poema nascer. Voltaremos a essa questão na análise da canção-poema.

\subsubsection{Análise da canção $O$ canto do Pajé}

Passemos, então, à análise da canção $O$ canto do Pajé, de autoria de Heitor Villa Lobos e C. Paula Barros. Villa Lobos é considerado por muitos o principal responsável pela descoberta de uma linguagem peculiarmente brasileira em música, compondo obras que enaltecem o espírito nacionalista, ao qual incorporou elementos das canções folclóricas, populares e indígenas. ${ }^{32}$ Após a investigação dos temas e figuras presentes na canção em foco,

\footnotetext{
${ }^{30}$ No CD Maria Bethânia 25 anos (1990/2006), que estamos analisando, a parte citada é o início (duas primeiras estrofes) de "O poeta come amendoim". Já no CD Brasileirinho (2003), Bethânia citou novamente o poema, juntamente com outra canção, porém a parte citada foi a última estrofe. Lembramos que o critério para a seleção dos poemas foi a diversidade de autores. Por essa razão, no caso desse último $\mathrm{CD}$, demos preferência ao poema de Vinícius de Moraes. Além disso, Brasileirinho (2003) possui outras particularidades, como, por exemplo, convidados para recitar ou ler alguns poemas: Ferreira Gullar e Denise Storlos.

${ }^{31}$ Ainda que o termo cor da pele possa soar um pouco estranho, preferimos seu uso, pois, para nós, não fica evidente, nesse trecho, que o tema subjacente seria raça.

${ }^{32}$ Dados disponíveis em: http://www.museuvillalobos.org.br/. Acesso em: 29 jan. 2013.
} 
com a consequente revelação da visão de mundo do seu enunciador (EC), mostraremos a hibridização desses dois textos.

\section{O CANTO DO PAJÉ 33}

Oh, manhã de sol

Anhangá fugiu

Anhangá rê rê

Ah, foi você

Quem me fez sonhar

Para chorar a minha terra

Coaracy rê rê

Anhangá fugiu

Oh Tupã Deus do Brasil

Que o céu enche de sol

De estrelas de luar e de

esperança

Oh, Tupã tira de mim esta

saudade

Ah, Anhangá me fez

Sonhar com a terra que perdi

Oh, manhã de sol

Anhangá fugiu

Canta a voz do rio

Canta a voz do mar

Tudo a sonhar

O céu e o mar

O campo, as flores

Oh manhã de sol

Anhangá fugiu

(BETHÂNIA, 1990 /2006)

O exame lexical das figuras "Pajé”, "Tupã”, "Anhangá”, "Coaracy" marca o discurso como pertencente ao folclore brasileiro, mais especificamente, à cultura indígena. Sob a figura de Anhangá, de que se lamenta a partida, encontra-se o tema da proteção da natureza, já que se trata de um espírito que tem por função "proteger a caça do campo" (CASCUDO, 1988, p. 23). Ele é o gênio da floresta, protetor da fauna e da flora.

Isso marca, de forma bastante significativa essa canção, pois a ausência de Anhangá significa a perda da terra que estava na posse dos indígenas: “Ah, Anhangá me fez / sonhar com a terra que perdi". A justificativa de que a terra pertencia aos índios está no fato de o dizer do poema ser atribuído a Tupã, chefe espiritual dos indígenas (ou alguém que

\footnotetext{
${ }^{33}$ No caso dessa canção, não foi possível citá-la na época de seu lançamento, pois não nos foi possível encontrar a gravação original de Villa Lobos.
} 
assume o seu lugar), como consta no próprio título. Assim, temos o tema da perda da terra que marca um nacionalismo às avessas, pois a terra cantada não é a terra possuída.

Esse tema maior remete a subtemas como: nostalgia ("Para chorar a minha terra"), consolo espiritual ("Oh, tupã tira de mim esta/ saudade") e sonho com a terra própria ("Tudo a sonhar/ o céu e o mar") que apontam para a formação ideológica do direito inalienável do índio à terra. Isso porque o $\mathrm{EC}$, ao expor esses (sub)tema(s), constrói uma isotopia temáticofigurativa para levar o enunciatário a valorizar os índios e sua cultura, cultura essa que, anteriormente, havia sido idealizada pelo Romantismo, mas que aqui é ressignificada para mostrar os índios como vítimas, e não como heróis.

\subsubsection{Análise de $O$ poeta come amendoim / $O$ canto do Pajé: um terceiro texto}

Dissemos anteriormente que o poema não foi citado na íntegra. Assim, preferimos reproduzir abaixo a canção-poema, exatamente da forma como foi apresentada no encarte do CD Maria Bethânia 25 anos (1990/2006):

Texto "Noites pesadas de cheiros e calores amontoados..

Foi o Sol que por todo o sítio imenso do Brasil

Andou marcando de moreno os brasileiros.

Estou pensando nos tempos de antes de eu nascer..." - Mário de Andrade

O CANTO DO PAJÉ

Oh, manhã de sol

Anhangá fugiu

Anhangá rê rê

Ah, foi você

Quem me fez sonhar

Para chorar a minha terra

Coaracy rê rê

Anhangá fugiu

Oh Tupã Deus do Brasil

Que o céu enche de sol

De estrelas de luar e de

esperança

Oh, Tupã tira de mim esta

saudade

Ah, Anhangá me fez

Sonhar com a terra que perdi 
Oh, manhã de sol

Anhangá fugiu

Canta a voz do rio

Canta a voz do mar

Tudo a sonhar

O céu e o mar

O campo, as flores

Oh manhã de sol

Anhangá fugiu

(BETHÂNIA, 1990/2006, faixa 1)

A introdução do texto, destacando a figura da gente morena presente em todo território nacional do Brasil ("Foi o Sol que por todo Sítio imenso do Brasil / andou marcando de moreno os brasileiros") é atrelada à história do país ("nos tempos de antes de eu nascer"). Não se trata de uma demarcação temporal exata, o que nos permite problematizar algumas investigações sobre a gênese da nacionalidade.

Para isso, recorremos ao trabalho de Ribeiro (2006). A historiadora, ao discorrer sobre a problemática do folclore brasileiro, afirma que

\begin{abstract}
envolvidos pelas ideias cientificistas, os primeiros estudiosos do folclore alegam renunciar às idealizações românticas e aderem às concepções naturalistas de raça, meio e evolução. É sobretudo em resposta aos estrangeiros naturalistas, surpreendidos pela mestiçagem humana e cultural observada no Brasil, que os folcloristas assumem a prática de investigação das influências raciais na formação da cultura popular, bem como da coleta e do registro documental da poesia e das narrativas orais. (RIBEIRO, 2006, p.149).
\end{abstract}

Voltando à canção-poema, agora com as informações expostas nesse excerto, podemos dizer que o tema mestiçagem encontra-se inscrito no discurso do ECP por meio das figuras "brasileiros morenos" e "índios". Assim, o problema da perda da terra é também daquela gente que o sol andou marcando, não apenas dos índios, o que é defendido pelo EC. Nesse sentido, a formação ideológica do direito à terra não é usada em favor apenas dos índios, mas de todos os brasileiros. Acreditamos, então, que, com esse novo percurso figurativo, "iluminado" pelo tema da mestiçagem, o ECP estende a todos os brasileiros o direito à terra, direito esse reservado, no discurso do EC, apenas aos índios. Trata-se, portanto, de uma formação ideológica que reconhece a necessidade de o Estado assegurar o acesso à terra a todos os cidadãos brasileiros, indistintamente.

Assim, por ampliar o problema da terra, o ECP, por meio do seu fazer-persuasivo, permite reflexões mais abrangentes. Por exemplo, no caso do indígena, a perda da terra talvez seja mais fácil de ser visualizada, uma vez que os índios eram autóctones. Nesse caso, a 
colonização do Brasil, na medida em que pressupõe a ocupação da terra por europeus, implica, simultaneamente, a perda da terra por parte dos índios.

Já no caso dos negros, o problema do acesso à terra parece ser mais difícil de visualizar. Como eles se encontravam sob o regime da escravidão, o anseio por liberdade pode ter, em parte, camuflado o problema da terra. Quando a escravidão foi abolida no Brasil, os negros ficaram sem terra, tanto que o surgimento das favelas geralmente é associado a essa questão. Tais reflexões só podem ser feitas a partir da visão de mundo do ECP e do tema da mestiçagem, convocado por ele, que pressupõe a relação de raças distintas, como os brancos, os índios e os negros.

É preciso ainda ressaltar que os outros temas revelados pela análise individual da canção não se excluem da canção-poema. Eles, na verdade, passam a amparar os brasileiros em geral. Por isso, temos uma persuasão instaurada no discurso da canção-poema que busca mobilizar as pessoas (ainda que apenas emocionalmente), em relação à necessidade de justiça para todos os brasileiros que perderam, por algum motivo, sua terra. Ou que não tiveram acesso a ela.

\subsection{Pátria minhal Melodia sentimental}

Brasileirinho foi um disco gravado em estúdio em 2003. Nele Maria Bethânia citou textos de autores importantes da Literatura brasileira, como Mário de Andrade, João Guimarães Rosa e Vinícius de Moraes. Desse trabalho, selecionamos a canção-poema Pátria minha/Melodia sentimental.

\subsubsection{Análise do poema Pátria minha}

Nascido no Rio de Janeiro, em 19 de outubro de 1913, o autor desse poema Vinícius de Moraes - também exerceu a carreira diplomática, nela ingressando em 1943. Aliás, segundo Menezes (2011, p. 223), “o tempo em que o poeta viveu fora do país, trabalhando como diplomata, coincide com seu gradual afastamento da poesia e com a aproximação a outras artes, como o teatro, o cinema e, principalmente a música popular”. O 
poeta manifestou-se contra a ditadura Vargas, pedindo a democracia. Esse posicionamento político repetiu-se durante o regime militar, acarretando a aposentadoria compulsória de Vinicius de Moraes, em 30 de abril de 1969. O poeta morreu em 10 de julho de 1980 (MENEZES, 2011).

Sobre o poema, trata-se de um dos textos do livro homônimo lançado em 1949. Abaixo transcrevemos o texto.

\section{PÁTRIA MINHA}

A minha pátria é como se não fosse, é íntima

Doçura e vontade de chorar; uma criança dormindo

É minha pátria. Por isso, no exílio

Assistindo dormir meu filho

Choro de saudades de minha pátria.

Se me perguntarem o que é a minha pátria, direi:

Não sei. De fato, não sei

Como, por que e quando a minha pátria

Mas sei que a minha pátria é a luz, o sal e a água

Que elaboram e liquefazem a minha mágoa

Em longas lágrimas amargas.

Vontade de beijar os olhos de minha pátria

De niná-la, de passar-lhe a mão pelos cabelos...

Vontade de mudar as cores do vestido (auriverde!) tão feias

De minha pátria, de minha pátria sem sapatos

E sem meias, pátria minha

Tão pobrinha!

Porque te amo tanto, pátria minha, eu que não tenho

Pátria, eu semente que nasci no vento

Eu que não vou e não venho, eu que permaneço

Em contato com a dor do tempo, eu elemento

De ligação entre a ação e o pensamento

Eu fio invisível no espaço de todo adeus

Eu, o sem Deus!

Tenho-te no entanto em mim como um gemido

De flor; tenho-te como um amor morrido

A quem se jurou; tenho-te como uma fé

Sem dogma; tenho-te em tudo em que não sinto a jeito

Nesta sala estrangeira com lareira

E sem pé direito.

Ah, pátria minha, lembra-me uma noite no Maine, Nova Inglaterra

Quando tudo passou a ser infinito e nada terra

E eu vi alfa e beta de Centauro escalarem o monte até o céu

Muitos me surpreenderam parado no campo sem luz

À espera de ver surgir a Cruz do Sul

Que eu sabia, mas amanheceu... 
Fonte de mel, bicho triste, pátria minha

Amada, idolatrada, salve, salve!

Que mais doce esperança acorrentada

O não poder dizer-te: aguarda...

Não tardo!

Quero rever-te, pátria minha, e para

Rever-te me esqueci de tudo

Fui cego, estropiado, surdo, mudo

Vi minha humilde morte cara a cara

Rasguei poemas, mulheres, horizontes

Fiquei simples, sem fontes.

Pátria minha... A minha pátria não é florão, nem ostenta

Lábaro não; a minha pátria é desolação

De caminhos, a minha pátria é terra sedenta

E praia branca; a minha pátria é o grande rio secular

Que bebe nuvem, come terra

E urina mar.

Mais do que a mais garrida a minha pátria tem

Uma quentura, um querer bem, um bem

Um libertas quae sera tamem

Que um dia traduzi num exame escrito:

"Liberta que será também"

E repito!

Ponho no vento o ouvido e escuto a brisa

Que brinca em teus cabelos e te alisa

Pátria minha, e perfuma o teu chão...

Que vontade que me vem de adormecer-me

Entre teus doces montes, pátria minha

Atento à fome em tuas entranhas

$\mathrm{E}$ ao batuque em teu coração.

Não te direi o nome, pátria minha

Teu nome é pátria amada, é patriazinha

Não rima com mãe gentil

Vives em mim como uma filha, que és

Uma ilha de ternura: a Ilha

Brasil, talvez.

Agora chamarei a amiga cotovia

E pedirei que peça ao rouxinol do dia

Que peça ao sabiá

Para levar-te presto este avigrama:

"Pátria minha, saudades de quem te ama...

Vinícius de Moraes".

(MORAES, 1949/2005, p. 94-96, grifo do autor).

Encontramos nesse poema vários temas, como o exílio, a melancolia, a nacionalidade, o subdesenvolvimento etc. Veremos agora, como alguns desses temas são particularmente importantes para a apreensão da visão de mundo do EP. 
Deparamo-nos, assim, com uma (in)definição subjetiva de pátria, e, por conseguinte, de patriotismo ou nacionalismo. Para que o discurso seja coerente, a recorrência de traços deve confirmar o que a análise de "pátria minha" sugere. De fato, ao analisarmos "A minha pátria é como se não fosse, é íntima/ Doçura e vontade de chorar; uma criança dormindo/ É minha pátria/ Mas sei que a minha pátria é a luz, o sal e a água/ Que elaboram e liquefazem a minha mágoa/ Em longas lágrimas amargas”, percebemos os temas do intimismo e da melancolia, o que demonstra o subjetivismo do narrador ao expor seus sentimentos pela pátria.

Tal subjetivismo tem uma importância fundamental, pois coloca o sentimento de amor à pátria acima de definições. $\mathrm{O}$ sentimento do narrador (enquanto projeção do EP) não se enquadra, portanto, em definições objetivas de nacionalidade, como, por exemplo, a nacionalidade baseada em descendência (Ius sanguinis) ou por local de nascimento (Ius solis). É isso que depreendemos da análise de: "Porque te amo tanto, pátria minha, eu que não tenho/ Pátria, eu semente que nasci no vento/ Eu que não vou e não venho, eu que permaneço/ Em contato com a dor do tempo, eu elemento/ Eu fio invisível no espaço de todo adeus/ Eu, o sem Deus”. Reparemos que a única justificativa dos sentimentos do narrador pela sua pátria é amar tanto. Assim, repete-se o tema do intimismo, ligado, de forma privilegiada, ao tema ${ }^{34}$ do amor.

É, sobretudo, por meio dessa espécie de amor incondicional que se mostra o caráter peculiar do contrato de veridicção do enunciador do poema (EP). Isso porque o que se exaltam no poema não são os valores nacionais; ao contrário, alguns desses elementos são menosprezados pelo narrador: "Vontade de mudar as cores do vestido (auriverde!) tão feias / De minha pátria, de minha pátria sem sapatos/ E sem meias, pátria minha/ Tão pobrinha/ Pátria minha... A minha pátria não é florão, nem ostenta/ Lábaro não; a minha pátria é desolação/ De caminhos, a minha pátria é terra sedenta/ Não te direi o nome, pátria minha/ Teu nome é pátria amada, é patriazinha/ Não rima com mãe gentil”. Essa desvalorização, contudo, não se destina a pôr em evidência o tema do antinacionalismo, mas, sim, a ressaltar um nacionalismo que ultrapassa interesses políticos, econômicos etc., remetendo, assim, a uma forma peculiar de amor intimista à pátria.

\footnotetext{
${ }^{34}$ Lembramos que lexemas como amor, ódio, amizade etc. também remetem às paixões que, via de regra, são analisadas no nível narrativo, nível esse que, pelas razões já expostas, estamos contemplando apenas de forma pontual em algumas análises.
} 
Esse sentimento é refinado pela presença de temas, como a afetividade e o desejo. É o que sobressai na análise do trecho: "vontade de beijar os olhos de minha pátria/ De ninála, de passar-lhe a mão pelos cabelos/ Ponho no vento o ouvido e escuto a brisa/ Que brinca em teus cabelos e te alisa/ Pátria minha, e perfuma o teu chão.../Que vontade que me vem de adormecer-me/Entre teus doces montes, pátria minha/ Atento à fome em tuas entranhas/ E ao batuque em teu coração". Por meio desses temas chegamos, então, ao tema do lirismo amoroso. Vemos, aliás, traços peculiares que podem ser encontrados em grande parte da poesia de Vinicius de Moraes, o que faz dele, fundamentalmente, "um poeta do amor", que cantou esse sentimento, de várias formas: "a paixão desenfreada, o sofrimento pela indiferença, ou pela rejeição da amada. A beleza da mulher, sua sensualidade, sua brandura, sua delicadeza e sua força..." (OMRAN, 2010, p. 11).

No entanto, precisamos ressaltar que se trata de uma forma peculiar da visão de mundo do enunciador. De fato, na análise do poema, vemos que, para declarar seu amor à pátria, o EP o faz pelo prisma do lirismo amoroso. Só que isso não significa a exclusão de outros temas. Por exemplo, o subdesenvolvimento ("tão pobrinha") demonstra certo engajamento político. Mas o que importa é que a visão de mundo que o EP quer passar para seu enunciatário é a de que o amor supera esses outros temas. Com isso, vemos que amar a pátria não é exaltar elementos ditos nacionais, é, simplesmente, dedicar-lhe o amor como se ela fosse a mulher amada.

\subsubsection{Análise da canção Melodia sentimental}

Melodia sentimental foi feita a partir de uma letra de Dora Vasconcellos, que além de poetiza, foi também embaixatriz ${ }^{35}$, para uma música de Heitor Villa-Lobos. Foi parte integrante da obra A floresta do Amazonas, do referido compositor, que teve papel importante no modernismo brasileiro. Ela também fez parte da trilha sonora do filme Deus é brasileiro, de Cacá Diegues.

\footnotetext{
${ }^{35}$ Dados disponíveis em: http://sebozanella.blogspot.com.br/2011/10/dora-vasconcelos-poetisa_17.html. Acesso em: 26 jan. 2013.
} 
A concepção musical de caráter nacional de Villa-Lobos já havia começado a ser traçada desde, aproximadamente, 1917. O compositor (1887-1959) fez uma transposição erudita do choro, acrescentando a esse gênero popular elementos pertencentes ao folclore popular de distintas regiões ${ }^{36}$. Reproduzimos, a seguir, a letra da canção, fazendo referência ao seu registro, datado de 1969.

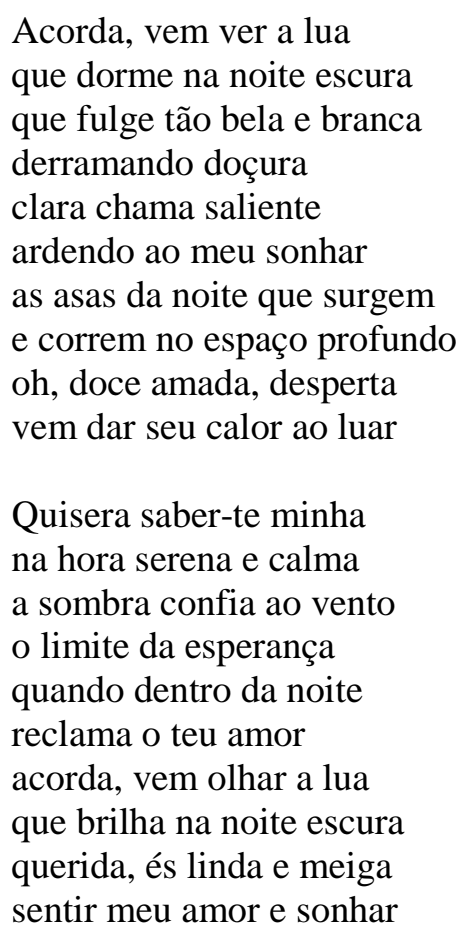

(VILLA-LOBOS; VASCONCELLOS, 1969)

Nessa canção, destaca-se a oposição entre o escuro e o claro. Assim, as figuras "as asas da noite", "espaço profundo", "sombra" e "noite escura" remetem à escuridão e, por meio dela, a temas como ininteligibilidade e melancolia. Esses temas, ao se relacionarem com o tema do amor (“Oh, doce amada”), desencadeariam o percurso temático-figurativo de um amor duvidoso ("Quisera saber-te minha”), em que os amantes não se entregariam um ao outro completamente.

Já as figuras "fulge tão bela e branca", "clara chama" e "brilha", remetendo à claridade, sugerem temas como transparência e fidelidade, o que revela o percurso temáticofigurativo do amor, ao mesmo tempo, terno ("doçura", "doce amada", "serena e calma", "meiga") e pleno de desejo (“ardendo ao meu sonhar", "sentir o meu amor e sonhar").

\footnotetext{
${ }^{36}$ Dados disponíveis em: http://www.museuvillalobos.org.br/. Acesso em: 29 jan. 2013.
} 
Assim, o ato de querer mostrar a lua à amada ("acorda", "ver", "desperta", "olhar") é uma forma de o narrador declarar-lhe seu amor puro (fiel, terno), apesar do anoitecer. Constrói-se, portanto, um paralelo entre o clareamento da noite pela lua e a honestidade do amor declarado à amada, aproximando-se os percursos temático-figurativos de um e de outra. Vemos, então, que o EC quer persuadir o enunciatário da existência de um amor puro entre dois seres humanos, fazendo sobressair os temas da ternura, da fidelidade e do desejo, imbricados com o sentimento amoroso do narrador pela amada, ainda que ele não tenha certeza de ser correspondido.

\subsubsection{Análise de Pátria minha/ Melodia sentimental: um terceiro texto}

Reproduzimos a seguir essa canção-poema, da forma como ela foi apresentada no encarte do CD Brasileirinho. Ressaltamos que essa articulação entre os dois gêneros também foi encontrada no DVD brasileirinho ao vivo (BETHÂNIA, 2004).

Se me perguntarem o que é minha pátria, direi:

Não sei. De fato, não sei

Como, por que e quando a minha pátria

Mas sei que a minha pátria é a luz, o sal e a água

Que elaboram e liquefazem a minha mágoa

Em longas lágrimas amargas.

Vontade de beijar os olhos de minha pátria

De niná-la, de passar-lhe a mão pelos cabelos...

Poema

pátria minha (trecho)

Vinicius de Moraes

Acorda, vem ver a lua que dorme na noite escura que fulge tão bela e branca derramando doçura clara chama saliente ardendo ao meu sonhar as asas da noite que surgem e correm no espaço profundo oh, doce amada, desperta vem dar seu calor ao luar

Quisera saber-te minha na hora serena e calma a sombra confia ao vento 


\begin{abstract}
o limite da esperança quando dentro da noite reclama o teu amor acorda, vem olhar a lua que brilha na noite escura querida, és linda e meiga sentir meu amor e sonhar
\end{abstract} (BETHÂNIA, 2003, faixa 12)

Começamos a análise apontando uma hipótese: se os trechos mobilizados pela intérprete fossem interrompidos na primeira estrofe, certamente a hibridização dos dois textos não seria tão eficaz do ponto de vista da coerência. Poderíamos até mesmo dizer que se trataria de uma incoerência temático-figurativa, visto que os temas e figuras no terceiro texto (tomado como um todo significativo) seriam incompatíveis entre si. Porém, esse terceiro-texto não só é coerente, como também mostra a eficiência de uma proposta de significação repleta de efeitos de sentidos outros, atribuídos ao ECP.

Dos percursos temático-figurativos presentes no poema analisado de forma individualizada, só sobressaem, no trecho destacado pelo ECP, o nacionalismo intimista. Entretanto, para a percepção de tal tema, é preciso visualizar, primeiramente, a dificuldade de se (in)definir pátria. Esse tema encontra-se subjacente a "Se me perguntarem o que é minha pátria, direi:/ Não sei. De fato, não sei/ Como, por que e quando a minha pátria". Tal dificuldade leva-nos ao tom intimista assumido pelo narrador do poema.

Acontece que esse tema do amor intimista à pátria ocorre com a figurativização da nação como uma mulher. É justamente o que vemos na segunda estrofe: "vontade de beijar os olhos de minha pátria", "de niná-la", "de passar-lhe as mãos pelos cabelos”. Esse trecho cria uma isotopia que nos permite compreender que a "doce amada" da canção, para o ECP, é a "minha pátria" (do enunciador). Assim, no contrato enunciativo proposto ao enunciatário por $\mathrm{ECP}$, encontramos a visibilidade da pátria enquanto mulher amada, merecedora de uma exaltação amorosa (a canção), declarada publicamente, como demonstração de afeto e transparência. Trata-se de um amor puro e totalmente intimista que não contém nenhum traço de objetividade.

É significativo observar o posicionamento diferente que ECP assume na articulação dessa canção-poema. Enquanto nas outras canções-poemas estudadas as determinações ideológicas instauradas no/pelo discurso projetam, claramente, a imagem de um sujeito engajado socialmente (FI feminista, FI de direito à terra), no caso dessa cançãopoema, o sujeito parece satisfazer-se apenas com a figurativização da pátria como mulher, uma construção recorrente - e diríamos mesmo estereotipada - no discurso literário. 


\subsection{Poema do menino Jesus/ Doce mistério da vida}

Em 1971, Maria Bethânia realizava o espetáculo Rosa dos ventos, que deu origem ao disco Rosa dos ventos - show encantado (BETHÂNIA, 1971/2011). Partes do poema citado pela intérprete são de autoria de Alberto Caeiro, um dos heterônimos do poeta português Fernando Pessoa, autor, aliás, que teve um espaço privilegiado na obra de Maria Bethânia. Houve, inclusive, um disco em que foram feitas citações somente desse poeta e de seus heterônimos: Imitação da vida (1997).

\subsubsection{Análise do poema $V I I I$}

Alberto Caeiro foi concebido por Fernando Pessoa em 1889, tendo falecido, de acordo com seu criador, em 1915. Embora tenha nascido em Lisboa, viveu a maior parte de sua vida no campo. Não tinha profissão e contava apenas com instrução primária. Após a morte prematura de seus pais, deixou-se ficar em casa, vivendo com uma tia-avó (CAEIRO, 1911-1912/2011, p.17-25).

Sobre a obra $O$ guardador de rebanhos (1911-1912/2011), na qual o poema em foco foi publicado originalmente, Fernando Pessoa revelou em carta ao poeta A. Casais Monteiro, datada de 13 de janeiro de 1935:

\footnotetext{
Ano e meio, ou dois anos depois, lembrei-me um dia de fazer uma partida ao SáCarneiro - de inventar um poeta bucólico, de espécie complicada, e apresentar-lho, já me não lembro como, em qualquer espécie de realidade. Levei uns dias a elaborar o poeta mas nada consegui. Num dia em que finalmente desistira - foi em 8 de março de 1914 - acerquei-me de uma cômoda alta, e tomando um papel, comecei a escrever, de pé, como escrevo sempre que posso. E escrevi trinta e tantos poemas a fio, numa espécie de êxtase cuja natureza não conseguirei definir. Foi o dia triunfal da minha vida, e nunca poderei ter outro assim. Abri com um título - 'O guardador de rebanhos'. E o que se seguiu foi o aparecimento de alguém em mim, a quem dei desde logo o nome de Alberto Caeiro. Desculpe-me o absurdo da frase: aparecera em mim o meu mestre (CAEIRO, 1911-1912/2011, p. 20-21 grifo do autor).
}

Como podemos ver, esse excerto contextualiza o surgimento da obra $O$ guardador de rebanhos e, por conseguinte, o nascimento do heterônimo Alberto Caeiro, com sua vida e estilo próprios. 
Passemos, então, à análise do Poema do menino Jesus. Antes, porém, fazemos algumas observações. Na edição que estamos utilizando, Caeiro (2011), o poema não foi identificado pelo título de Poema do menino Jesus, e sim por um número: VIII. Além disso, há uma nota que julgamos importante reproduzir abaixo (em rodapé), já que ela contém informações relevantes para os nossos objetivos de análise. Por último, dada a extensão do poema, optamos por distinguir, já nesse primeiro momento, as partes que não foram citadas por Maria Bethânia (em itálico) daquelas que o foram (em letra normal), para que, quando ocorra a análise da canção-poema, possamos recordar mais facilmente as partes citadas, uma vez que elas não estão juntas, mas disseminadas ao longo do texto.

\section{VIII $^{37}$}

Num meio-dia de fim de primavera

Tive um sonho como uma fotografia.

Vi Jesus Cristo descer à terra.

Veio pela encosta de um monte

Tornado outra vez menino,

A correr e a rolar-se pela erva

E a rir de modo a ouvir-se de longe.

Tinha fugido do céu.

Era nosso demais para fingir

De segunda pessoa da Trindade.

No céu era tudo falso, tudo em desacordo

Com flores e árvores e pedras.

No céu tinha que estar sempre sério

$E$ de vez em quando de se tornar outra vez homem

E subir para a cruz, e estar sempre a morrer

Com uma coroa toda à roda de espinhos

E os pés espetados por um prego com cabeça,

E até com um trapo à roda da cintura

Como os pretos nas ilustrações.

Nem sequer o deixavam ter pai e mãe

Como as outras crianças.

O seu pai era duas pessoas -

Um velho chamado José, que era carpinteiro,

E que não era pai dele;

E o outro pai era uma pomba estúpida,

A única pomba feia do mundo

Porque não era do mundo nem era pomba.

E a sua mãe não tinha amado antes de o ter.

\footnotetext{
${ }^{37}$ Nota presente na edição de Caeiro (2011): "Diz o autor em carta de 3 de dezembro de 1930 a João Gaspar Simões: 'O que lhe poderei enviar, se quiser, é o oitavo poema de $O$ guardador de rebanhos, ou seja, o poema sobre a vinda de Cristo à terra, que não publiquei na Athena por o que é de ofensivo para a Igreja Católica: nem isso convinha à Athena, como publicação em geral, nem estava certo, sendo católico o Rui Vaz, diretor comigo da revista e proprietário dela."
} 
Não era mulher: era uma mala

Em que ela tinha vindo do céu.

E queriam que ele, que só nascera da mãe,

E nunca tivera pai para amar com respeito,

Pregasse a bondade e a justiça!

Um dia que Deus estava a dormir

E o Espírito Santo andava a voar,

Ele foi à caixa dos milagres e roubou três.

Com o primeiro fez que ninguém soubesse que ele tinha fugido.

Com o segundo criou-se eternamente humano e menino.

Com o terceiro criou um Cristo eternamente na cruz

E deixou-o pregado na cruz que há no céu

E serve de modelo às outras.

Depois fugiu para o sol

E desceu pelo primeiro raio que apanhou.

Hoje vive na minha aldeia comigo.

É uma criança bonita de riso e natural.

Limpa o nariz ao braço direito,

Chapinha nas poças de água,

Colhe as flores e gosta delas e esquece-as.

Atira pedras aos burros,

Rouba as frutas dos pomares

E foge a chorar e a gritar dos cães.

$\mathrm{E}$, porque sabe que elas não gostam

E que toda a gente acha graça,

Corre atrás das raparigas

Que vão em ranchos pelas estradas

Com as bilhas às cabeças

E levanta-lhes as saias.

A mim ensinou-me tudo.

Ensinou-me a olhar para as cousas.

Aponta-me todas as cousas que há nas flores.

Mostra-me como as pedras são engraçadas

Quando a gente as tem na mão

E olha devagar para elas.

Diz-me muito mal de Deus.

Diz que ele é um velho estúpido e doente,

Sempre a escarrar no chão

E a dizer indecências.

A virgem Maria leva as tardes da eternidade a fazer meia.

E o Espírito Santo coça-se com o bico

E empoleira-se nas cadeiras e suja-as.

Tudo no céu é estúpido como a Igreja Católica.

Diz-me que Deus não percebe nada

Das coisas que criou-

"Se é que ele as criou, do que duvido" -

"Ele diz, por exemplo, que os seres cantam a sua glória,

Mas os seres não cantam nada.

Se cantassem seriam cantores.

Os seres existem e mais nada,

E por isso se chamam seres". 
E depois, cansado de dizer mal de Deus,

O menino Jesus adormece nos meus braços

E eu levo-o ao colo para casa.

Ele mora comigo na minha casa a meio do outeiro.

Ele é a Eterna Criança, o deus que faltava.

Ele é o humano que é natural,

Ele é o divino que sorri e que brinca.

E por isso é que sei com toda certeza

Que ele é o Menino Jesus verdadeiro.

E a criança tão humana que é divina

É esta minha quotidiana vida de poeta,

E é porque ele anda sempre comigo que eu sou poeta sempre,

E que o meu mínimo olhar

Me enche de sensação,

E o mais pequeno som, seja do que for,

Parece falar comigo.

A criança nova que habita onde vivo

Dá-me uma mão a mim

E a outra a tudo que existe

E assim vamos os três pelo caminho que houver,

Saltando e cantando e rindo

E gozando o nosso segredo comum

Que é o de saber por toda a parte

Que não há mistério no mundo

E que tudo vale a pena.

A Criança Eterna acompanha-me sempre.

A direção do meu olhar é o seu dedo apontando.

O meu ouvido atento alegremente a todos os sons

São as cócegas que ele me faz, brincando, nas orelhas.

Damo-nos tão bem um com o outro

Na companhia de tudo

Que nunca pensamos um no outro,

Mas vivemos juntos os dois

Com um acordo íntimo

Como a mão direita e a esquerda.

Ao anoitecer brincamos as cinco pedrinhas

No degrau da porta de casa,

Graves como convém a um deus e a um poeta,

E como se cada pedra

Fosse todo um universo

E fosse por isso um grande perigo para ela

Deixá-la cair no chão.

Depois eu conto-lhe histórias das cousas só dos homens

E ele sorri, porque tudo é incrível.

Ri dos reis e dos que não são reis,

E tem pena de ouvir falar das guerras, 
E dos comércios, e dos navios

Que ficam fumo no ar dos altos-mares.

Porque ele sabe que tudo isso falta àquela verdade

Que uma flor tem ao florescer

E que anda com a luz do sol

A variar os montes e os vales

E a fazer doer aos olhos os muros caiados.

Depois ele adormece e eu deito-o.

Levo-o ao colo para dentro de casa

E deito-o, despindo-o lentamente

E como seguindo um ritual muito limpo

E todo materno até ele estar nu.

Ele dorme dentro da minha alma

E às vezes acorda de noite

E brinca com os meus sonhos.

Vira uns de pernas para o ar,

Põe uns em cima dos outros

E bate as palmas sozinho

Sorrindo para o meu sono.

Quando eu morrer, filinho,

Seja eu a criança, o mais pequeno.

Pega-me tu ao colo

E leva-me para dentro da tua casa.

Despe o meu ser cansado e humano

E deita-me na tua cama.

E conta-me histórias, caso eu acorde,

Para eu tornar a adormecer.

E dá-me sonhos teus para eu brincar

Até que nasça qualquer dia

Que tu sabes qual é.

Esta é a história do meu Menino Jesus.

Por que razão que se perceba

Não há de ser ela mais verdadeira

Que tudo quanto os filósofos pensam

E tudo quanto as religiões ensinam?

(CAEIRO, 1911-1912/2011, p. 49-54, grifo nosso).

Analisemos agora os temas e figuras mais relevantes. Temos, nesse poema, figuras que nos revelam temas relacionados ao universo religioso, mais especificamente, à religião cristã (católica). Uma dessas figuras, Jesus Cristo, é inclusive o protagonista. No entanto, sabemos por meio da Semiótica Francesa que uma figura, quando tomada isoladamente, não é suficiente para nos revelar a totalidade de sentido de um texto; ela deve ser inserida em percursos. São esses "encadeamentos" de figuras e temas que vão evidenciar pareceres de sentido possíveis para o texto. 
Para começar, um fato bastante relevante é que a figura de Jesus Cristo, nesse poema, decorre de "um sonho como uma fotografia". Essa última figura sugere que o enunciador do poema está mais próximo de relações com objetos do mundo natural do que com objetos de um mundo sobrenatural - caso, por exemplo, de Maria, quando recebeu o anjo Gabriel, anunciando a vinda do Messias (LUCAS 1, 26-28).

No poema, a própria vinda desse menino Jesus à terra não revela nada de sobrenatural. Ao contrário, mostra-se um sujeito que volta como menino e que, nessa condição, só sabe fazer (ou mostrar que sabe fazer) ações naturais (cotidianas) de uma pessoa (uma criança) comum: "Ele veio pela encosta de um monte, / mas era outra vez menino, / a correr e a rolar-se pela erva/ e a arrancar flores pra deitar fora, / e a rir de modo a ouvir-se de longe".

Outro ponto em que nos deteremos é que, no discurso cristão, a figura de Jesus Cristo é tomada como exemplo para sustentar temas como a salvação, a obediência etc. Entretanto, no poema, do ponto de vista da sintaxe narrativa, para que o menino Jesus entrasse em conjunção com a terra, ou melhor, com o traço de humanidade, ele contradiz os exemplos (os valores) relacionados à figura cristã: "Ele tinha fugido do céu/ ele foi até a caixa dos milagres e roubou três". Aqui temos o inverso dos ensinamentos bíblicos. O céu é uma espécie de casa para o Menino Jesus. Ele, porém, não honra o pai (ÊXODO, 20, 12), uma vez que foge para a terra. Além disso, comete o pecado de roubar para a realização da fuga

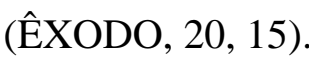

Apenas isso já revela uma contraposição entre os valores inscritos na figura do Menino Jesus de Alberto Caeiro e aqueles referentes ao Menino Jesus cristão. Essa oposição é enfatizada pela ridicularização das figuras cristãs: "No céu era tudo falso"; "E subir para cruz, e estar sempre a morrer"; "Um velho chamado José, que era carpinteiro / E que não era pai dele / E o outro pai era uma pomba estúpida"; "E a sua mãe não tinha amado antes de o ter/ Não era mulher: era uma mala"; "Diz-me muito mal de Deus./ Diz que ele é um velho estúpido e doente, / sempre a escarrar no chão/ E a dizer indecências/ A virgem Maria leva as tardes da eternidade a fazer meia. / E o espírito santo coça-se com o bico / E empoleira-se nas cadeiras e suja-as. / Tudo no céu é estúpido como a Igreja Católica”. Em síntese: todas essas figuras, que constroem uma espécie de anti-percurso, revelam o tema da materialidade: como o pai é velho, ele está doente; mulher de idade faz, por exemplo, tricô; pombo coça-se com o bico. Ou seja, todas essas ações não se relacionam com o tema da espiritualidade, mas com o da blasfêmia, já que o EP insulta a religião, mais especificamente, os postulados ou dogmas da Igreja Católica. 
Além disso, nos ensinamentos que o menino Jesus de Alberto Caeiro procura deixar para os seus "irmãos" da terra não há nada de divino, o que também contraria a ideologia cristã, a começar pelo lugar de sua permanência na terra, visto apenas como uma aldeia. Assim, como nos conta o narrador, ele realiza apenas ações ligadas ao cotidiano de crianças comuns, como já foi dito: "Limpa o nariz com o braço direito/ chapinha nas poças d’água, / colhe as flores, gosta delas e esquece. / Atira pedras aos buracos, colhe as frutas dos pomares/ e foge a chorar e a gritar dos cães. / E só porque sabe que elas não gostam/ e que toda gente acha graça, ele/ corre atrás das raparigas que levam/ as bilhas nas cabeças/ e levanta-lhes a saia".

Essas figuras, no entanto, vão além da cotidianidade, em direção a um tema maior: o da inexplicabilidade da vida. Não há uma sabedoria a ser revelada. O menino Jesus do poema sabe fazer o que, pressupõe-se, todos os habitantes da aldeia já sabiam fazer. Aliás, esse tema condiz com algumas características do éthos desse heterônimo apontadas por Fiorin (2008a, p. 63-65): “Caeiro não admite a poesia socialmente engajada” (...) A poesia de Caeiro "constrói a imagem de um homem instintivo e rústico" (...) "Caeiro coloca-se no polo da natureza".

No que diz respeito aos ensinamentos em termos mais explícitos - e voltados para o narrador/personagem, já que o poema é um relato em $1^{\mathrm{a}}$. pessoa - o menino Jesus quis que ele entrasse em conjunção com coisas simples da própria vida, coisas essas que provavelmente todos nós fizemos algum dia, quando éramos crianças. Assim, do ponto de vista do EP, não há ensinamentos sobrenaturais: apenas a observação do que há no mundo, algo natural, mas que é caracterizado como tudo: "A mim ele me ensinou tudo. / Ele me ensinou a olhar para as coisas, / ele me aponta todas as cores que há nas flores, / e me mostra como as pedras são engraçadas/ quando a gente as tem na mão e olha de vagar para elas./ Nos damos tão bem um com o outro, / na companhia de tudo, / que nunca pensamos um no outro. / Vivemos juntos os dois com um / acordo íntimo, /como a mão direita e a esquerda”.

Junte-se ao que foi exposto o fato de figuras como "brincar, sorrir, contar histórias, adormecer" também contribuírem para a construção de um percurso tematizado como simplesmente viver. É como se todo e qualquer saber fazer fosse a revelação do mais íntimo da vida. Inclusive, quando aparece a figura da morte, o que o narrador pede ao menino Jesus é para fazer justamente o que ele fez com o menino, quando este adormeceu: "Quando eu morrer, filinho, / seja eu a criança, o mais pequeno, / pega-me tu ao colo / e leva-me para dentro da tua casa. / Deita-me na tua cama, / e despe meu ser cansado e humano. / E conta-me histórias, caso eu acorde, / para tornar a adormecer. / E dá-me sonhos teus para eu brincar". 
Como podemos observar, não há promessas, simplesmente remissões a um saber fazer já conhecido.

$\mathrm{Na}$ última estrofe, vem a pergunta sobre por que o menino Jesus do poema não teria a mesma veracidade que os ensinamentos filosóficos e religiosos: "Não há de ser ela mais verdadeira/ Que tudo quanto os filósofos pensam/ E tudo quanto as religiões ensinam?" Percebemos, então, a razão pela qual EP convoca determinados temas e figuras para compor seu fazer-persuasivo: ele espera que, por meio da oposição entre um mundo natural (valorizado, legitimado) e um mundo espiritual (desvalorizado, renegado), o enunciatário perceba as determinações ideológicas antirreligiosas e antifilosóficas que propõem verdades universais, inquestionáveis. Temos, assim, o tema da ruptura com verdades universais e um contrato de veridicção, estabelecido entre enunciador e enunciatário, em defesa da vida natural, que apenas deve ser vivida.

Essa análise dos temas e figuras desse poema vai em direção à constatação de Perrone-Moisés (2001, p. 162) de que "o menino Jesus de Caeiro não ensina a ver nas coisas outra coisa (a Providência, simbolizada em sua obra), mas elas mesmas...". Em termos mais gerais, nossa análise coincide também com alguns apontamentos que a autora faz, evidenciando alguns aspectos peculiares da obra desse heterônimo de Fernando Pessoa: a) o paradoxo de explicar que não há nada a explicar; b) o fato de a poesia de Caeiro possuir sua própria teoria, que é não teorizar; c) o teor didático da poesia de Caeiro. O que a autora faz é propor uma espécie de quadro estético da poesia de Alberto Caeiro. E percebemos que esses elementos estéticos estão relacionados, de alguma forma, com a análise dos temas e figuras aqui apresentada.

\subsubsection{Análise da canção Doce mistério da vida}

Reproduzimos, a seguir, a canção Doce mistério da vida, que é uma versão brasileira de Alberto Ribeiro para Ah, Sweet Mystery Of Life, de Victor Herbert. Esclarecemos que o brasileiro Alberto Ribeiro (1902-1971) foi compositor e cantor, tendo composto, inclusive, algumas das mais famosas marchas carnavalescas e juninas do Brasil, em parceria com João do Barro ${ }^{38}$. Já o irlandês Victor Herbert (1859-1924) foi compositor, violoncelista e maestro, tendo ficado bastante conhecido por suas operetas, lançadas na Broadway de 1890

\footnotetext{
${ }^{38}$ Dados disponíveis em: http://pt.wikipedia.org/wiki/Alberto_Ribeiro. Acesso em: 26 jan. 2013.
} 
até a Primeira Guerra Mundial ${ }^{39}$. A reprodução dessa canção será feita tal como o texto se apresenta no encarte do próprio álbum de Maria Bethânia.

\author{
Minha vida que parece muito calma \\ Tem segredos que não posso revelar \\ Escondidos bem no fundo de minh`alma \\ Não transparecem nem sequer \\ em um olhar \\ Vive sempre conversando a sós comigo \\ Uma voz que eu escuto com fervor \\ Escolheu meu coração pra seu abrigo \\ E dele fez um roseiral em flor \\ A ninguém revelarei o meu segredo \\ E nem direi quem é o meu amor \\ (BETHÂNIA, 1971/2011, faixa 6)
}

O enunciador dessa canção (EC) coloca em evidência a distinção entre o parecer e o ser, como se pode ver, por exemplo, no trecho: "minha vida que parece muito calma/ Tem segredos que eu não posso revelar". Assim, a "vida tranquila" é correlata à mentira (ou ilusão) - parece, mas não é -, pois há segredos não revelados (articulação entre o ser e o não parecer), o que remete à espiritualidade, que pode ser resgatada pelas figuras: "Vive sempre conversando a sós comigo /Uma voz que eu escuto com fervor / Escolheu meu coração para seu abrigo / E dele fez um roseiral em flor”. Essa espiritualidade, contudo, não está sujeita a uma religião institucionalizada. Trata-se apenas de uma espiritualidade que evidencia a importância da não revelação dos segredos, entre os quais o amor.

Nessa canção, ao contrário do poema anterior, os valores do EC não estão relacionados ao saber fazer do cotidiano. Aqui, o contrato de veridicção busca levar o enunciatário a reconhecer a importância da espiritualidade, mas sem especificá-la. O que se valoriza é uma vida com segredos, um viver oculto, que não revela ao outro a essência, o que se mostra, portanto, oposto ao que é defendido pelo EP: "gozando nosso segredo comum/ que é o de saber por toda parte/ que não há mistério no mundo/ E que tudo vale a pena”. Assim, EC mostra que não se conhece alguém verdadeiramente (ou seja, pela essência, pela espiritualidade, que fica atrelada aos segredos, à intimidade), mas apenas pela aparência (pelo que ele dá a ver externamente). Temos, então, a valorização da espiritualidade, numa perspectiva que beira o filosófico.

\footnotetext{
${ }^{39}$ Dados disponíveis em: http://en.wikipedia.org/wiki/Victor_Herbert. Acesso em: 26 jan. 2013.
} 


\subsubsection{Análise de Poema do menino Jesus / Doce mistério da vida: um terceiro texto}

Inicialmente, reproduzimos abaixo a junção dos dois textos apresentada no encarte do CD Rosa dos ventos show encantado (BETHÂNIA, 1971/2011). Ressaltamos, também, que essa junção apareceu em outro CD, Maricotinha ao vivo (BETHÂNIA, 2002). Essa reiteração reforça nossa defesa de classificar a junção canção-poema como um terceiro texto, uma vez que sua circulação ocorreu, inclusive, em contextos diferentes, o que também pôde ser observado na canção-poema Pátria minha/ Melodia sentimental já analisada (ver item 2.3.3).

\section{Texto $\mathbf{n}^{0} 2$}

(Fernando Pessoa)

\section{Doce mistério da vida}

(Ah! Sweet Mystery Of Life)

(Victor Herbet/Versão: Alberto Ribeiro)

- Num meio-dia de fim de primavera

Eu tive um sonho com uma fotografia.

Eu vi Jesus Cristo descer à terra.

Ele veio pela encosta de um monte, mas era outra vez menino,

a correr e a rolar-se pela erva

e a arrancar flores pra deitar fora,

e a rir de modo a ouvir-se de longe.

Ele tinha fugido do céu.

Era nosso demais para fingir

de segunda pessoa da Trindade.

Um dia, que Deus estava dormindo

e o Espírito Santo andava a voar,

ele foi até a caixa dos milagres

e roubou três.

Com o primeiro, ele fez que ninguém

soubesse que ele tinha fugido.

Com o segundo, ele se criou eternamente humano e menino.

Com o terceiro, ele criou um

Cristo na cruz

E o deixou pregado na cruz que há no céu

e serve de modelo às outras.

Depois ele fugiu para o sol

e desceu pelo primeiro raio que apanhou.

Hoje ele vive na minha aldeia comigo.

É uma criança bonita de riso e natural.

Limpa o nariz com o braço direito,

chapinha nas poças d’água, 
colhe as flores, gosta delas e esquece.

Atira pedras aos burros,

colhe as frutas dos pomares

e foge a chorar e a gritar dos cães.

E só porque sabe que elas não gostam

e que toda gente acha graça, ele

corre atrás das raparigas que levam

as bilhas nas cabeças

e levanta-lhes a saia.

A mim ele me ensinou tudo.

Ele me ensinou a olhar para as coisas, ele me aponta todas as cores que

há nas flores,

e me mostra como as pedras

são engraçadas

quando a gente as tem na mão

e olha devagar para elas.

Nos demos tão bem um com o outro, na companhia de tudo,

que nunca pensamos um no outro.

Vivemos juntos os dois com um

acordo íntimo,

como a mão direita e a esquerda.

Ao anoitecer, nós brincamos as

cinco pedrinhas

no degrau da porta de casa,

graves como convém a um deus

e a um poeta.

É como se cada pedra

fosse todo um universo

e fosse por isso um perigo muito grande

deixá-la cair no chão.

Depois eu lhe conto a história das coisas

só dos homens.

Ele sorri, porque tudo é incrível.

Ele ri dos reis e dos que não são reis,

e tem pena de ouvir falar das guerras e,

dos comércios.

Depois ele adormece e o levo

no colo para dentro da minha casa

e deito-o na minha cama,

despindo-o lentamente,

e como seguindo um ritual todo humano

e todo materno até Ele estar nu.

Ele dorme dentro da minha alma,

Ele, às vezes, acorda de noite

e brinca com meus sonhos.

Vira uns de pernas pro ar,

põe uns em cima dos outros,

e bate palmas sozinho

sorrindo para o meu sono.

Quando eu morrer, filhinho,

seja eu a criança, o mais pequeno,

pega-me tu ao colo

e leva-me para dentro da tua casa. 
Deita-me na tua cama,

e despe meu ser cansado e humano.

E conta-me histórias, caso eu acorde,

para tornar a adormecer.

E dá-me sonhos teus para eu brincar.

Minha vida que parece muito calma

Tem segredos que não posso revelar

Escondidos bem no fundo de minh alma

Não transparecem nem sequer

em um olhar

Vive sempre conversando a sós comigo

Uma voz que eu escuto com fervor

Escolheu meu coração pra seu abrigo

E dele fez um roseiral em flor

A ninguém revelarei o meu segredo

E nem direi quem é o meu amor

(BETHÂNIA, 1971/2011, faixa 6)

Iniciamos a análise pela supressão feita por Maria Bethânia das partes do poema de Alberto Caeiro (já sinalizadas no item 2.4.1.). Essa eliminação coincide com a exclusão do tema da ridicularização das figuras cristãs, ou melhor, da blasfêmia e também com a supressão do tema da quebra das verdades universais, mostrando que, no contrato de veridicção da canção-poema, não há a valorização de determinações ideológicas antirreligiosas e antifilosóficas (da perspectiva do EP). Ao contrário, os temas e figuras revelados na canção-poema apontam noutra direção. Por outro lado, alguns temas revelados na análise individual do poema também percorrem a visão de mundo do $\mathrm{ECP}$, como revela o exame da canção-poema.

Em linhas gerais, podemos dizer que, quando realiza a junção da canção com trechos convenientemente escolhidos do poema, o ECP assume, prioritariamente, os valores defendidos pelo EC. Assim, no fazer persuasivo do ECP, encontram-se temas como a religiosidade e a filosofia. Entretanto, temos que ressaltar que não se trata de uma religião institucionalizada ou de uma filosofia específica. Trata-se apenas de reconhecer que faz parte do viver (do homem) algo de procedência sobrenatural.

Essa procedência sobrenatural não é oposta à imagem de homem "natural" valorizada pelo EP; é, antes, reenquadrada no aspecto sobrenatural assumido pelo ECP, a partir de EC, como se vê nos versos apresentados pelo narrador: "[minha vida] vive sempre conversando a sós comigo/ uma voz que eu escuto com fervor/ escolheu meu coração pra seu abrigo/ E dele fez um roseiral em flor”. Ora, como se vê, o diálogo, na canção-poema, não se dá com alguém humanizado, como acontece no poema: "Ele é o humano que é natural”. Isso 
nos faz refletir sobre o sobrenatural. Para tanto, apoiamo-nos no percurso instaurado pelas figuras: "sonho", "segredos", "vida", “alma".

A questão é que o EP opõe-se ao sobrenatural por atribuir-lhe uma noção do "fora do comum", de algo "não natural". Entretanto, Alves (2006, p. 83-97) dá-nos informações relevantes sobre a religião, relacionando-a com alguns princípios filosóficos. No capítulo $A$ voz do desejo, o autor propõe a relação entre sonhos e religião. "As Religiões são os sonhos dos que estão acordados". Esse excerto nos remete a um entendimento do valor do natural defendido por Caeiro, que é tomado como algo pertencente ao sobrenatural pelo ECP. Sonhar é algo natural, tanto que o próprio narrador do poema tem um sonho com uma fotografia mas é claro que o EP aproxima o sonho da realidade para dar coerência ao seu discurso.

De forma mais ampla, podemos dizer que o ECP valoriza a religiosidade; não uma religião específica, institucionalizada. Exemplificamos essa diferença com este excerto que nos revela a mais inesperada das conclusões sobre o que é religião:

Espelho. É isto: a linguagem religiosa é um espelho em que se reflete aquilo que mais amamos, nossa própria essência. $\mathrm{O}$ que a religião afirma é a divindade do homem, o caráter sagrado dos seus valores, o absoluto do seu corpo, a bondade de viver, comer, ouvir, cheirar, ver... Assim, chega-se à mais espantosa das conclusões desse homem que amava a religião e nela encontrava a revelação dos segredos de sua própria alma: “O segredo da religião é o ateísmo” (ALVES, 2006, p. 96).

Ressaltamos a importância do termo ateísmo. Até porque o próprio Caeiro é visto por alguns estudiosos como ateu. Entretanto, repetimos, trata-se de uma oposição à institucionalização da religião, mesmo se a religiosidade defendida na canção-poema seja mais tolerante, menos agressiva, do que aquela que se manifesta no poema, tomado isoladamente, visto que o ECP não ridiculariza figuras e dogmas da Igreja Católica, como faz EP.

\subsection{Aniversário/ Uma canção desnaturada}

Em 1997, Maria Bethânia lançou o álbum Imitação da vida. Nesse trabalho, a intérprete apresentou vários textos (e não apenas poemas) de Fernando Pessoa e seus heterônimos imbricados a algumas canções. Algumas dessas citações remetiam ao livro do Desassossego, do ortônimo, que é, em geral, classificado como livro de ficção. 
Ainda que admitamos a importância, em termos discursivos, de uma análise integral dessa obra, selecionamos a canção-poema Aniversário/Uma canção desnaturada, em consonância com os objetivos propostos para esta dissertação. O poema mobilizado pela intérprete, nessa ocasião, é de autoria de Álvaro de Campos, um dos principais heterônimos do poeta português Fernando Pessoa.

\subsubsection{Análise do poema Aniversário}

Antes de iniciarmos a análise desse poema, vejamos alguns dados relativos à sua autoria. Álvaro de Campos é, juntamente com Alberto Caeiro e Ricardo Reis, os três principais heterônimos de Fernando Pessoa. Na crítica literária, geralmente Campos é visto como o único heterônimo pessoano que passa por diferentes fases poéticas: decadentista (simbolista), futurista (modernista) e intimista (pessimista). Outras informações sobre ele dão conta de que era engenheiro, teve educação inglesa e experimentava a sensação de sempre ser estrangeiro, independentemente do lugar onde se encontrava (MOISÉS, 1998).

De acordo com Moisés (1998), consta que o nascimento (fictício, já que ele é uma "personagem" criada por Fernando Pessoa) desse heterônimo foi registrado em 15 de outubro de 1890. Já a data do seu óbito é ainda hoje uma incógnita. Sobre a sua profissão e educação, lembra-nos o autor que a justificava para que os estudos de Álvaro de Campos ocorressem em Glasgow, e não em Portugal, estaria relacionada à qualidade da ciência náutica dos britânicos. Outro dado relevante apontado por Moisés (1998) é o fato de que, assim como ocorreu com Fernando Pessoa, Álvaro de Campos não chegou a reunir poemas numa mesma obra, ou seja, os poemas atribuídos a ele foram publicados de forma avulsa. Um exemplo disso está na própria estreia do poeta, no primeiro número da revista Orpheu, em janeiro de 1915, com o poema No canal de Suez, a bordo.

Abaixo, citamos o poema a ser analisado na íntegra, embora, como veremos, Bethânia não o cite por inteiro.

\section{Aniversário}

No tempo em que festejavam o dia dos meus anos,

Eu era feliz e ninguém estava morto.

Na casa antiga, até eu fazer anos era uma tradição de há séculos, $\mathrm{E}$ a alegria de todos, e a minha, estava certa com uma religião qualquer. 
No tempo em que festejavam o dia dos meus anos,

Eu tinha a grande saúde de não perceber coisa nenhuma,

De ser inteligente para entre a família,

E de não ter as esperanças que os outros tinham por mim.

Quando vim a ter esperanças, já não sabia ter esperanças.

Quando vim a olhar para vida, perdera o sentido da vida.

Sim, o que fui de suposto a mim-mesmo,

O que fui de coração e parentesco.

$\mathrm{O}$ que fui de serões de meia província,

O que fui de amarem-me e eu ser menino,

O que fui - ai, meu Deus!, o que só hoje sei que fui...

A que distância!...

(Nem o acho...)

O tempo em que festejavam o dia dos meus anos!

O que eu sou hoje é como a umidade no corredor do fim da casa,

Pondo grelado nas paredes...

O que eu sou hoje (e a casa dos que me amaram tremem através das minhas lágrimas),

O que eu sou hoje é terem vendido a casa,

É terem morrido todos,

É estar eu sobrevivente a mim-mesmo como um fósforo frio...

No tempo em que festejavam o dia dos meus anos...

Que meu amor, como uma pessoa, esse tempo!

Desejo físico da alma de se encontrar ali outra vez,

Por uma viagem metafísica e carnal,

Com uma dualidade de eu para mim...

Comer o passado como pão de fome, sem tempo de manteiga nos dentes!

Vejo tudo outra vez com uma nitidez que me cega para o que há aqui:

A mesa posta com mais lugares, com melhores desenhos na loiça, com mais copos,

O aparador com muitas coisas - doces, frutas, o resto na sombra debaixo do alçado -,

As tias velhas, os primos diferentes, e tudo era por minha causa,

No tempo em que festejavam o dia dos meus anos...

Para, meu coração!

Não penses! Deixa o pensar na cabeça!

Ó meu Deus, meu Deus, meu Deus!

Hoje já não faço anos.

Duro.

Somam-se-me dias.

Serei velho quando o for.

Mais nada.

Raiva de não ter trazido o passado roubado na algibeira!...

O tempo em que festejavam o dia dos meus anos!...

(CAMPOS, 1929/2008, p. 22). 
Nesse poema, salta aos olhos a diferença entre presente e passado. Vejamos, então, quais temas estão subjacentes a esses tempos e por meio de quais temas e figuras podemos chegar à visão de mundo do EP.

Podemos dizer que o tempo passado é figurativizado como tempo da afeição, uma vez que a felicidade, a saúde, a inocência e a esperança são temas que o narrador relaciona ao instinto de proteção gerado pela companhia familiar durante a infância. Disso, podemos depreender outro tema que é o do sentido da vida ("novo", "o que fui", "menino", "tradição"). Ou seja, para o narrador do poema, a vida na infância estava repleta de significado. Tratava-se da novidade da vida, da definição do "eu" (ou melhor, do ser).

A figurativização do presente dá-se pelo oposto do passado. O presente é o tempo da solidão, como se depreende de: "o que eu sou hoje", "É terem morrido todos", "A mesa posta com mais lugares, com melhores desenhos na loiça, com mais / copos, / o aparador com muitas coisas - doces, frutas, o resto na sombra debaixo do / alçado -, / As tias velhas, os primos diferentes, e tudo era por minha causa". O tema da solidão, por sua vez, convoca os temas da tristeza, do desafeto e da desesperança. Por isso mesmo, ao invés do sentido da vida, tem-se no presente a sobrevida, como podemos depreender de: "olhar para vida", "umidade no corredor do fim da casa", "estar sobrevivente a mim-mesmo como um fósforo frio...", “Hoje já não faço anos. / Duro". Como se vê, trata-se apenas de uma sobrevivência. Não há perspectivas de vida: sonhos ou esperanças. Isso ocorria apenas no passado, ou melhor, na infância do narrador.

Vemos, assim, que o passado é valorizado positivamente, enquanto o presente - e também o futuro ("Serei velho quando o for. /Mais nada") - é desvalorizado pelo narrador (o que, por tabela, revela ou desvela os valores do enunciador sobre os quais o texto se apóia). Tanto que há o tema de resgate do passado ${ }^{40} \mathrm{em}$ "Que meu amor, como uma pessoa, esse tempo! / Desejo físico da alma de se encontrar ali outra vez, / Por uma viagem metafísica e carnal, / Com uma dualidade de eu para mim.../ Comer o passado como pão de fome, sem tempo de manteiga nos dentes!”. Na realidade, esse último tema pode ser substituído por outro, que acreditamos ser uma espécie de macrotema, por se sobrepor à maioria dos temas anteriores: trata-se da identidade do próprio "Eu". Esse macrotema, inclusive, coincide com a seguinte opinião de Moisés (1998, p. 63): “A grande constante temática da poesia de Álvaro

\footnotetext{
40 Vale a pena ressaltar que, do ponto de vista narrativo, o sujeito pode ser classificado como um sujeito virtual ou virtualizado (ver LARA; MATE, 2009), uma vez que ele quer reviver o passado, mas não pode, exatamente por estar em disjunção com o objeto de valor (o sentido da vida que se encontra no passado). É por isso que ele sofre paixões como a tristeza, a solidão etc., que coincidem com muitos dos temas apontados em nossa análise.
} 
de Campos, o 'assunto' com que ele se preocupa o tempo todo, é o seu próprio Eu, a sua identidade".

Podemos dizer, enfim, que o contrato de veridicção do EP está baseado na valorização de um sujeito (exemplificado pelo narrador do poema) em busca do sentido da vida. Trata-se, em última instância, de uma formação ideológica filosófica, mais precisamente daquela filosofia presente em textos como os do filósofo dinamarquês Sören Kierkegaard (1813-1855), para quem a grande questão é "encontrar uma verdade, mas uma verdade para mim, encontrar a ideia pela qual e para a qual quero viver e morrer" (JOLIVET apud MOISÉS, 1998, p. 98). No caso do poema analisado, a verdade que o EP quer passar ao enunciatário é que existe vida apenas na infância e que, após essa fase, só nos resta a sobrevida.

\subsubsection{Análise da canção Uma canção desnaturada}

A canção a ser analisada aqui é de Chico Buarque, compositor cujas canções são uma constante na carreira de Maria Bethânia. Inclusive, nos anos 2011 e 2012, ela fez um show em homenagem ao colega: Show Maria Bethânia canta Chico Buarque.

Seguem alguns dados biográficos do autor da canção. Francisco Buarque de Hollanda nasceu em 19 de junho de 1944. Lançou seu primeiro disco em 1965. Além de compositor, Chico Buarque também escreveu peças de teatro e romances. Seu último $\mathrm{CD}, \mathrm{Na}$ carreira, foi lançado em 2012. No caso da canção a ser analisada, trata-se de uma composição

feita para a versão paulista da peça de teatro Ópera do malandro ${ }^{41}$. Abaixo, segue a reprodução da letra para fins de análise.

\section{Uma canção desnaturada}

Por que cresceste, curuminha

Assim depressa, e estabanada

Saíste maquiada

Dentro do meu vestido

Se fosse permitido

Eu revertia o tempo

Pra viver a tempo

De poder

\footnotetext{
${ }^{41}$ Dados disponíveis em: http://www.chicobuarque.com.br/. Acesso em 26 jan. 2013.
} 
Te ver as pernas bambas, curuminha

Batendo com a moleira

Te emporcalhando inteira

E eu te negar meu colo

Recuperar as noites, curuminha

Que atravessei em claro

Ignorar teu choro

E só cuidar de mim

Deixar-te arder em febre, curuminha

Cinquenta graus, tossir, bater o queixo

Vestir-te com desleixo

Tratar uma ama-seca

Quebrar tua boneca, curuminha

Raspar os teus cabelos

E ir te exibindo pelos

Botequins

Tornar azeite o leite

Do peito que mirraste

No chão que engatinhaste, salpicar

Mil cacos de vidro

Pelo cordão perdido

Te recolher pra sempre

À escuridão do ventre, curuminha

De onde não deverias

Nunca ter saído

(BUARQUE, 1979, faixa 4)

O primeiro tema que destacamos nessa canção é a "desumanização" da maternidade. Isso porque ao rejeitar a maternidade ("Te ver as pernas bambas, curiminha/ Batendo com a moleira/ Te emporcalhando inteira/ E eu te negar meu colo/ ignorar teu choro/ Deixar-te arder em febre, curiminha/ cinquenta graus, tossir, bater o queixo / vestir-te com desleixo/ tratar uma ama-seca/ Quebrar tua boneca, curuminha"), a narradora ${ }^{42}$ nega alguns atributos relacionados a ela, tais como o carinho, o cuidado, a proteção.

Com isso, chegamos ao tema da desvalorização da família, atrelado ao tema do egoísmo (relacionado à criança/curuminha): "Recuperar as noites, curuminha/ Que atravessei em claro/ Ignorar teu choro/ E só cuidar de mim", no sentido de que, ao cuidar da criança, a narradora perdeu o tempo que teria para cuidar de si mesma e de poder realizar seus sonhos ou pretensões: "Se fosse permitido / Eu revertia o tempo/ Para viver a tempo/ De poder". Essa espécie de valorização do individualismo não parece ser, contudo, extrema ou pejorativa; pelo contrário, ela surge para marcar uma oposição à maternidade. Assim, o que o EC procura mostrar é uma narradora descontente com o papel materno (sem planejamento) que

\footnotetext{
${ }^{42}$ Usamos o termo no feminino, neste caso, porque, ao que tudo indica, quem fala, no texto, é uma "voz" feminina, atrelada, portanto, ao "lugar" social de mãe.
} 
interrompe o curso de sua vida com a imposição da dedicação à filha. Nesse sentido, o texto mostra-se condizente com o discurso feminista, que defende a decisão da mulher no processo de reprodução.

Essa relação ficará ainda mais clara se analisarmos, de forma mais pormenorizada, a expressão "de poder". Para isso, remetemo-nos brevemente a uma questão abordada no nível narrativo do percurso gerativo de sentido. Trata-se da questão das modalidades, que podem ser definidas, de forma bastante sucinta, como "as condições necessárias ou facultativas da ação transformadora dos actantes" (FONTANILLE, 2011, p. 172). Sem entrar em muitos detalhes, ressaltamos apenas as seguintes diferenças: "O querer e o saber modificam a relação entre o sujeito e seu objeto (...) o dever e o poder modificam a relação entre o sujeito e um terceiro, seja esse terceiro um destinador (no caso do dever) ou um adversário (no caso do poder)" (FONTANILLE, 2011, p. 175; grifos do autor).

Nessa perspectiva, quando a narradora diz "Se fosse permitido / Eu revertia o tempo/ Para viver a tempo/ De poder", ela se opõe a um antissujeito (adversário) implícito. Assim, o que a narradora quer é uma relação de sujeito para sujeito, rejeitando a posição de (quase) objeto a que foi relegada por um outro sujeito (Estado/instituições/homens) e da qual quer afastar-se ("Se fosse permitido/ Eu revertia o tempo...”). O trecho a seguir ilustra essa questão:

\footnotetext{
Mas quando na formulação de outras políticas de população foram ouvidas as mulheres? Em matéria de reprodução só não tem voz aqueles que parem. As mulheres, de sujeito desta história toda, do processo de reprodução, foram convertidas em objeto. Por nossos corpos e desejos passam os interesses do Estado, das instituições, dos homens, e ao sabor das orientações político-econômicas nos mandam e pedem que procriemos ou que deixemos de procriar (CASTRO, 1980, p. 226-227).
}

Surge, a partir daí, o tema do aborto, que, na letra da canção, pode ser associado às figuras presentes, por exemplo, no trecho "Te recolher pra sempre, curuminha/ De onde não deverias/ Nunca ter saído". Juntando a esses termos a expressão "Se fosse permitido", sobressai um matiz desse tema, problematização, inclusive, mais contemporânea, que é o tema da descriminalização do aborto, tema esse destacado, sobretudo, em textos cujas posições ideológicas feministas sobressaem direta ou indiretamente. No excerto abaixo, vemos essa questão de forma explícita/direta:

(...) nós mulheres feministas somos a favor da legalização do aborto, do acesso a contracepção, como direito a mulher ter os filhos que deseja, na perspectiva não de realização de metas político-econômicas, de defesa de determinados interesses de grupos no poder, ouse de um bem-estar de uma população em abstrato, mas tendo como princípio de que a cada mulher deveria ser dado o direito de decidir sobre suas vidas (CASTRO, 1980, p. 230). 
A partir da apreensão do tema do feminismo, temos que olhar de forma mais atenta para o tema egoísmo, já apontado anteriormente. Esse egoísmo, apontado e assumido pela narradora (enquanto projeção do enunciador e de seus valores no texto-enunciado), devese ao fato de a família ser vista no discurso feminista como um dos principais núcleos da discriminação da mulher, por reafirmar seu papel de reprodutora biológica dos homens e da "reprodução material e cultural do sistema" (CASTRO, 1980, p. 224).

Outro fato relevante que a análise demonstra é que a rejeição da maternidade não está relacionada à rejeição de qualquer criança, mas de uma criança do sexo feminino. A narradora repele a curiminha, termo presente em todas as estrofes da canção, evidenciando uma desvalorização do papel feminino, cuja única perspectiva de vida é a prostituição: "Raspar os teus cabelos/ E ir te exibindo pelos/ Botequins".

Além disso, com a rejeição da maternidade, o EC, por meio da narradora, opõe-se a formações ideológicas que defendiam o crescimento demográfico, como se pode verificar, por exemplo, em alguns documentos do Governo Médici, em 1974, momento em que se considera que "um alto efetivo populacional seria básico à consecução da meta de que o Brasil, em uma geração, alcançasse o posto de quarta potência mundial" (CASTRO, 1980, p. 227).

Portanto, podemos dizer que o EC procura persuadir o enunciatário, através dos temas e figuras relacionados à experiência da narradora, evidenciando que a infância da criança do sexo feminino (“curuminha") não apresenta nenhum aspecto que deveria ser valorizado ou idealizado do ponto de vista da maternidade que se impõe à mulher. A persuasão que o EC tenta impor ao enunciatário é, pois, da ordem da desvalorização do papel materno da mulher, o que aponta para uma formação ideológica de individualização, para que a mulher se sinta (ou possa se sentir) realizada, tomando suas próprias decisões, inclusive aquelas relacionadas ao querer/não querer ser mãe.

É importante ressaltar que o universo feminino é uma constante na obra de Chico Buarque. Por isso mesmo, há um bom número de estudos sobre essa temática. Assim, observamos algumas coincidências de nossa análise com o que diz Meneses sobre a canção em foco:

Mas sobretudo o sacrossanto amor materno, sancionado pela Natureza e consagrado pela sociedade, é desmistificado em Uma Canção Desnaturada, mostrando sua contraface de raiva e egoísmo. Chega-se a um ponto em que a corrosão da crítica arranca não apenas a máscara, mas a pele cobre o rosto social. Um ponto perigoso, uma situação limite (MENESES, 2001, p. 73). 
Subjacente à letra da canção de Chico Buarque, encontra-se, pois, uma formação ideológica feminista, uma vez que a desmistificação do amor materno significa, em outras palavras, o direito de a mulher ter ou não filhos.

\subsubsection{Análise de Aniversário/Uma canção desnaturada: um terceiro texto}

Para empreender a análise da canção-poema, reproduzimos, a seguir, os trechos do poema Aniversário ${ }^{43}$ mobilizados por Maria Bethânia e, em seguida, a letra de Uma canção desnaturada.

No tempo em que festejavam o dia dos meus anos.

Eu era feliz e ninguém estava morto.

Na casa antiga, até eu fazer anos era uma tradição de há séculos,

E a alegria de todos, e a minha,

Estava certa com uma religião qualquer.

No tempo em que festejavam o dia dos meus anos,

Eu tinha a grande saúde de não perceber coisa nenhuma,

De ser inteligente para entre a família,

$E$ de não ter as esperanças que os outros tinham por mim.

Quando vim a ter esperanças, já não sabia ter esperanças.

Uma canção desnaturada

Por que cresceste, curuminha

Assim depressa, e estabanada

Saíste maquiada

Dentro do meu vestido

Se fosse permitido

Eu revertia o tempo

Para viver a tempo

De poder

Te ver as pernas bambas, curuminha

Batendo com a moleira'

Te emporcalhando inteira

E eu te negar meu colo

Recuperar as noites, curuminha

Que atravessei em claro

Ignorar teu choro

E só cuidar de mim

\footnotetext{
${ }^{43}$ Ressaltamos que o encarte do CD Imitação da vida apresenta os textos de Fernando Pessoa e seus heterônimos entre aspas e com seus respectivos créditos (como, por exemplo, "Aniversário" - Álvaro de Campos ou "Do poema 'Para Ser Grande' - Ricardo Reis" etc.). Já no que diz respeito às canções, não são citadas suas letras, apenas seus créditos no final do encarte, com exceção dos poemas que foram musicados.
} 
Deixar-te arder em febre, curuminha

Cinquenta graus, tossir, bater o queixo

Vestir-te com desleixo

Tratar uma ama-seca

Quebrar tua boneca, curuminha

Raspar os teus cabelos

E ir te exibindo pelos

Botequins

Tornar azeite o leite

Do peito que mirraste

No chão que engatinhaste, salpicar

Mil cacos de vidro

Pelo cordão perdido

Te recolher pra sempre

À escuridão do ventre, curuminha

De onde não deverias

Nunca ter saído

(BETHÂNIA, 1997, faixa 10).

Como podemos observar na canção-poema apresentada, as partes do poema mobilizadas pelo ECP coincidem com aquelas que apresentam temas e figuras que nos permitem afirmar a existência de um tempo passado, figurativizado como tempo de afeição e de sentido da vida. Já as partes relacionadas, sob a ótica do EP, à figurativização do tempo presente foram suprimidas.

Assim, o ECP sobrepõe o tempo presente do EC (o tempo "atual", em que a “curuminha” já está crescida), ao tempo presente do EP (o tempo da solidão do "eu”), substituindo os temas e figuras subjacentes ao discurso deste, pelos temas e figuras subjacentes ao discurso daquele. Isso sugere que a narradora da canção-poema encontra-se em um estágio de sobrevida não pela impossibilidade de reviver a infância, mas sim por ver nesta a exigência de uma dedicação materna que a impossibilita de viver o presente. Portanto, o ECP impõe o tema do egoísmo/individualismo, recusando-se a ver na infância algo tão positivo como faz crer o EP.

Cabe ressaltar que esse ponto de vista atribuído ao ECP é percebido por meio da análise temático-figurativa da canção-poema. Com isso, podemos dizer que há uma espécie de paradoxo proposto pelo ECP: de acordo com o narrador da canção-poema, a infância é, paralelamente, o tempo da afeição (tempo do poema) e do egoísmo (tempo da canção), uma vez que para ser cuidada a criança exige a atenção do outro e o impede de viver. No entanto, como o segundo tema é mais explorado (até do ponto de vista da extensão do texto incorporado), consideramos que, no contrato de veridicção desse terceiro texto, sobressaem os temas do egoísmo, do aborto, do feminismo, numa espécie de releitura ou ressignificação da 
infância (vista sob a ótica da mulher/mãe). Ao focalizar esses temas, o ECP quer persuadir o enunciatário de que ser sujeito de si mesmo é opor-se a determinações ideológicas, principalmente políticas, assumidas, em geral, sem discussão ou questionamento. No caso da mulher, isso implica opor-se a um discurso/uma ideologia, que a vê apenas como objeto, não lhe permitindo escolher modos de vida que lhe tragam o que ela mesma define como felicidade, afeição etc.

Esclarecemos, finalmente, que o termo "paradoxo", usado no parágrafo anterior, não deve ser tomado como figura de linguagem, nos moldes da gramática tradicional ou da estilística, mas na acepção defendida por Fiorin e Savioli (2001). Para esses autores, o paradoxo ou oxímoro "é um procedimento de construção textual que consiste em agrupar figuras ou temas de significados contrários numa mesma unidade de sentido" (FIORIN; SAVIOLI, 2001, p. 144). Lembrando que uma de nossas hipóteses é a de que a junção de textos dos gêneros poema e canção gera um novo texto, entendido como uma unidade de significação, fica clara a noção de paradoxo como mecanismo discursivo.

\subsection{E depois de uma tardel Amor de Índio}

Para comemorar 35 anos de carreira, a intérprete Maria Bethânia lançou em 2002 o CD Maricotinha ao vivo, trabalho em que a canção-poema em pauta foi interpretada. Tratase da junção de um poema de Sophia de Mello Breyner Andresen e uma canção de Beto Guedes e Ronaldo Bastos.

\subsubsection{Análise do poema $E$ depois de uma tarde}

Esse poema, como foi dito, é de autoria de Sophia de Mello Breyner Andresen, poetisa portuguesa, nascida no Porto, em 1919. Andresen também foi ativista política contra a ditadura de Salazar, chegando a ser, inclusive, deputada na Assembleia Constituinte pelo Partido Socialista. O poema pertencia ao primeiro livro de Andresen, intitulado Poesia, cuja publicação ocorreu em 1944. Antes disso, porém, ela já participava da revista Cadernos de poesia, sendo suas primeiras publicações datadas de 1940. A autora continuou suas atividades 
nessa revista, com alguns intervalos, até 1953 (ver REZENDE, 2006). Segue a reprodução do poema:

\author{
Apesar das ruínas e da morte, \\ Onde sempre acabou cada ilusão, \\ A força dos meus sonhos é tão forte, \\ Que de tudo renasce a exaltação \\ E nunca as minhas mãos ficam vazias.
}

(ANDRESEN, 1944/1991, p. 15)

Inicialmente, observamos, subjacente às figuras "ruínas" e "morte", o tema do fracasso, uma vez que tais figuras representam o lugar de origem (o "onde") da desilusão do narrador. Entretanto, tal tema não contribui para o engendramento de outros temas que seriam de esperar, como, por exemplo, o pessimismo. Sua presença, na realidade, é evocada para ser contraposta a um outro tema: a motivação dos sonhos. Esse último tema pode ser apreendido pela análise do trecho iniciado pelo conector "apesar de", que convoca figuras como "a força dos meus sonhos", "é tão forte", "renasce a exaltação". Por último, enfatizamos o tema correlato do preenchimento do vazio existencial, figurativizado por: "E nunca as minhas mãos ficam vazias". Tal preenchimento ocorrerá com a exaltação do renascimento que surge de tudo. Em outras palavras: o otimismo do narrador faz com que ele se desvie do vazio existencial, vendo em tudo a possibilidade de renascimento.

Para a compreensão desse último tema tornam-se imprescindíveis alguns dados contextuais. De acordo com Rezende (2006, p. 89), “em Poesia e nas obras que imediatamente lhe seguiram, os temas de Sophia já apontavam para um renascimento resultante de um retorno à pureza inicial das coisas". Ora, é exatamente isso que ocorre no poema em análise: o narrador, valendo-se da redundância de traços: "A força dos meus sonhos é tão forte" (grifos nossos), exalta o renascimento de tudo, a partir dos seus sonhos, que se revelam, pois, mais fortes do que a desilusão provocada pelas ruínas e pela morte. Essas figuras ainda nos remetem a proposta de redescoberta da vida "em sua essência, subvertendo o caos a que chegou o mundo moderno", por causa, por exemplo, da Segunda Grande Guerra, presente, segundo Rezende (2006, p. 89), em muitos poemas de Andresen.

Essa questão da redescoberta da vida está relacionada justamente com o tema do preenchimento do vazio existencial. Portanto, podemos dizer que o EP busca persuadir o enunciatário de que não há concessões para os sonhos; pelo contrário, o confronto com a morte pode levar o sujeito "a ressignificar sua existência, a crescer para além de si e a renascer maior do que antes, mesmo estando à beira da morte" (CARNEIRO; ABRITTA, 
2008, p. 193). Em suma, o contrato de veridicção do poema em análise joga com o reconhecimento da necessidade de sonhar, apesar dos obstáculos e dificuldades impostos pelo mundo que nos rodeia.

\title{
2.6.2 Análise da canção Amor de Índio
}

A canção Amor de Índio foi composta por Beto Guedes e Ronaldo Bastos. Alberto de Castro Guedes nasceu em 13 de agosto de 1951. Seu primeiro disco solo foi lançado em 1977, tendo como título A página do Relâmpago. Esse trabalho rendeu ao intérprete e compositor um show de lançamento no Teatro Ipanema, em 1978. Assim, no embalo desse trabalho, lançou, nesse mesmo ano, seu segundo disco, Amor de Índio, cujo nome era justamente uma referência à primeira canção do disco (CAYMMI, 1997, p. 9-21). Sobre seu parceiro nessa canção, basta dizer que Ronaldo Bastos é um dos principais letristas mineiros, tendo feito parceria com vários músicos de importância nacional, como Milton Nascimento e Flávio Venturini. Reproduzimos, a seguir, a letra da canção:

\author{
Amor de Índio \\ Tudo que move é sagrado \\ E remove as montanhas \\ Com todo o cuidado \\ Meu amor \\ Enquanto a chama arder \\ Todo dia te ver passar \\ Tudo viver a teu lado \\ Com o arco da promessa \\ Do azul pintado \\ Pra durar \\ Abelha fazendo o mel \\ Vale o tempo que não voou \\ A estrela caiu do céu \\ $O$ pedido que se pensou \\ $\mathrm{O}$ destino que se cumpriu \\ De sentir seu calor \\ E ser todo \\ Todo dia é de viver \\ Para ser o que for \\ E ser tudo \\ Sim, todo amor é sagrado \\ E o fruto do trabalho \\ É mais que sagrado \\ Meu amor \\ A massa que faz o pão
}


Vale a luz do teu suor

Lembra que o sono é sagrado

E alimenta de horizontes

O tempo acordado de viver

No inverno te proteger

No verão sair pra pescar

No outono te conhecer

Primavera poder gostar

No estio me derreter

Pra na chuva dançar e andar junto

$\mathrm{O}$ destino que se cumpriu

De sentir seu calor e ser tudo

Sim, todo amor é sagrado

(GUEDES; BASTOS, 1978, faixa 1)

Amor é, sem dúvida alguma, o tema principal dessa canção. Entretanto, temos que verificar os matizes desse tema, por meio de uma análise temático-figurativa que nos permita apreender as relações contratuais entre enunciador (EC) e enunciatário. Isso porque, no nível discursivo, tais relações são alimentadas, entre outros mecanismos, pela presença de temas (e figuras) disseminados ao longo do texto. Logo, os temas, ao formarem percursos, e ser revestidos por figuras, mostram-nos qual o contrato específico proposto pelo enunciador da canção sobre o amor: o amor paixão, o amor platônico, o amor carnal, o amor espiritual etc.

Começaremos pelo tema do amor espiritual, verificado na análise de figuras como: "tudo que move é sagrado", "remove as montanhas", "Sim, todo amor é sagrado", "E o fruto do trabalho/ É mais que sagrado/ Meu amor". Com isso, vemos que o EC busca levar o enunciatário a crer num amor espiritual, que, sobretudo, transforma o olhar do amante numa espécie de "visão sagrada". Tal visão é tão forte que transforma a figurativização do tempo em durabilidade afetiva, apesar da finitude das coisas: "Enquanto a chama arder/ Todo dia te ver passar/ Tudo viver a teu lado/ Com o arco da promessa/ Do azul pintado/ pra durar/ A abelha fazendo mel/ Vale o tempo que não voou"; e, ao mesmo tempo, reitera o tema do carpe diem, principalmente, em "Todo dia é de viver/ Para ser o que for/ E ser tudo".

Esse tema do amor espiritual é incrementado pelo tema do destino (ou da inexorabilidade do encontro amoroso), que convoca não só temas mais frequentes do universo religioso, como a fidelidade ("tudo viver a teu lado/ Com o arco da promessa/ Do azul pintado/ Pra durar"), mas também temas evitados no/pelo discurso religioso, como o sexo/ amor carnal ("A estrela caiu do céu/ O pedido que se pensou/ O destino que se cumpriu/ De sentir seu calor/ e ser todo"), seja na indicação do calor dos corpos dos amantes, seja na sugestão imagética do coito - ser todo, significa, assim, a junção de duas partes (corpos) num todo (visualizado como um só corpo). 
Ao sugerir a junção de temas como a fidelidade e o sexo, por exemplo, o EC investe num contrato persuasivo no qual o enunciatário deve valorizar positivamente o amorpaixão (união do amor espiritual e do amor carnal). Trata-se de uma formação ideológica compatível, por exemplo, com a que se faz presente em determinados textos de Os cânticos de Salomão, já que "O clímax do Cântico dos Cânticos é o louvor do amor veemente e fiel" (CÂNTICO DOS CÂNTICOS DE SALOMÃO, 1999, p. 778).

Entretanto, o discurso amoroso presente no universo religioso não é unívoco. A própria Igreja, que usou textos bíblicos para mostrar a junção amor carnal/amor espiritual, usou também a Bíblia para condenar "todo amor profano, considerando-o antítese do amor sagrado. Ela insistia particularmente sobre os perigos do excesso de amor entre esposos" (PRIORE, 2007, p. 123). Aliás, o tema do excesso também se encontra presente na canção, enfatizado, principalmente, pela reiteração do pronome tudo (e variantes), como em: “O destino que se cumpriu/ De sentir seu calor e ser tudo".

Vejamos, brevemente, como essas questões foram abordadas no discurso religioso. De acordo com Priore (2007), ao longo da Idade Média, prevaleceram os ideais baseados no estoicismo, ou seja, na antiga moral cristã, que via a sexualidade como meio exclusivo de procriação. É por isso que "Santo Agostinho, no século V, resumia o casamento à procriação e ao cuidado com os filhos. O prazer puro e simples era 'concupiscência da carne', esterilidade que submetia a razão aos sentidos" (PRIORE, 2007, p. 123), chegando, inclusive a afirmar que a força do desejo não viria de Deus, mas de Satanás. Esses ideais, enquanto formação ideológica, ainda perduraram por bastante tempo. Um exemplo disso pode ser visto nos ideais do filósofo francês Decartes, já no século XVII: “o sexo era, por vezes, mencionado, mas na amizade, a razão tinha que dominar o ardor da carne. E a razão era, neste caso, vista como força ou obtenção divina” (PRIORE, 2007, p. 128-129).

Essa formação ideológica opõe-se àquela presente no discurso do EC. Esta coincidirá com a formação ideológica presente em textos veiculados a partir de meados do século XVIII. Nesse momento histórico, houve a junção das duas formas de amor (espiritual e carnal), vistas até então como opostas, o que permitiu o surgimento do amor-paixão, unindo essas duas vertentes. Nessa formação ideológica vemos o prazer como um direito dos amantes. Portanto, as relações contratuais estabelecidas entre o EC e seu enunciatário visam ao reconhecimento do amor-paixão como realização ${ }^{44}$ sagrada, evidenciando a junção corpoalma como essência do amor sentido/vivenciado pelo narrador da canção.

\footnotetext{
${ }^{44}$ Mais uma vez, convocamos uma categoria do nível narrativo, embora ele não seja nosso foco de investigação. Assim, o narrador da canção pode ser classificado como Sujeito Realizado, uma vez que ele se encontra em
} 


\subsubsection{Análise de $E$ depois de uma tarde/Amor de Índio: um terceiro texto}

Reproduzimos, a seguir, essa canção-poema. Antes, vale ressaltar que, no caso do CD Maricotinha ao vivo, a intérprete optou por não apresentar, no encarte, nem as letras das canções, nem os textos (de outros gêneros, como os poemas) mobilizados por ela. No entanto, os créditos desses textos foram registrados, o que basta para a análise que aqui empreendemos.

Apesar das ruínas e da morte,

Onde sempre acabou cada ilusão,

A força dos meus sonhos é tão forte,

Que de tudo renasce a exaltação

E nunca as minhas mãos ficam vazias.

Amor de Índio

Tudo que move é sagrado

E remove as montanhas

Com todo o cuidado

Meu amor

Enquanto a chama arder

Todo dia te ver passar

Tudo viver a teu lado

Com o arco da promessa

Do azul pintado

Pra durar

Abelha fazendo o mel

Vale o tempo que não voou

A estrela caiu do céu

$O$ pedido que se pensou

$\mathrm{O}$ destino que se cumpriu

De sentir seu calor

E ser todo

Todo dia é de viver

Para ser o que for

E ser tudo

Sim, todo amor é sagrado

E o fruto do trabalho

É mais que sagrado

Meu amor

A massa que faz o pão

Vale a luz do teu suor

Lembra que o sono é sagrado

E alimenta de horizontes

O tempo acordado de viver

conjunção com o objeto de valor, a mulher amada, já tendo realizado a transformação da disjunção para a conjunção (cf. LARA; MATTE, 2009, p. 37). 
No inverno te proteger

No verão sair pra pescar

No outono te conhecer

Primavera poder gostar

No estio me derreter

Pra na chuva dançar e andar junto

$\mathrm{O}$ destino que se cumpriu

De sentir seu calor e ser tudo

Sim, todo amor é sagrado

(BETHÂNIA, 2002, Faixas 22-23)

Ao juntar esses dois textos, o ECP coloca em evidência o lado conflituoso do amor, como podemos ver em "ruínas", "mortes", “acabou cada ilusão", propondo, assim, um olhar mais restrito sobre os sonhos, ao contrário de toda abrangência proposta pelo EP. Nesse último caso, trata-se de sonhos múltiplos; já no primeiro, podemos restringir essa motivação ao sonho do amor-paixão.

A articulação do início do poema ("Apesar das ruínas e da morte/ Onde sempre acabou cada ilusão") com o final da letra da canção ("O destino que se cumpriu/ De sentir seu calor/ E ser todo"), agora lidos como partes de um mesmo texto, relatado por um único narrador (o da canção-poema), sugere o tema da repressão sexual ${ }^{45}$, em favor da pureza espiritual. Tais temas se justificam pelo fato de a combinação entre os temas do amor carnal e da frustração amorosa estar relacionada a uma formação ideológica que assume a incompatibilidade entre essas duas formas de amor, o que podemos ver em textos que remontam à época do Renascimento:

Para as igrejas cristãs, toda a relação sexual que não tivesse por fim imediato a procriação se confundia com prostituição. Em toda a Europa, as autoridades religiosas tiveram sucesso em transformar o ato sexual, e qualquer atrativo feminino, em tentação diabólica. Na Itália, para ficar num exemplo, se condenava à morte os homens que beijassem uma mulher casada, na Inglaterra, decapitavam-se as adúlteras, e em Portugal, queimavam-se, em praça pública, os sodomitas (PRIORE, 2007, p. 128).

Essa formação ideológica não se restringe, no entanto, ao universo religioso. O mesmo autor menciona também exemplos na literatura que reafirmam essa postura: "No teatro elisabetano, por exemplo, quando se apresentava a ideia de um poderoso amor, ao mesmo tempo carnal e espiritual, ligava-se diretamente ao tema da paixão e da morte", como é o caso de Romeu e Julieta (PRIORE, 2007, p. 127).

\footnotetext{
${ }^{45}$ Para uma melhor compreensão desse tema, há que se compreender que o narrador-personagem da cançãopoema quer entrar em conjunção com o amor-paixão, mas para ser um sujeito plenamente realizado, ele deverá passar pelas ruínas e vencer a morte, que podem, portanto, (re)figurativizar o tema da repressão sexual.
} 
Vemos, finalmente, que o enfrentamento dos obstáculos (pela força do sonho/desejo) também influenciará o tema do preenchimento do vazio existencial, fazendo com que este incida, agora, sobre o amor-paixão. Assim, as relações contratuais que o ECP estabelece em seu discurso têm como objetivo uma adesão ao amor-paixão, visto como elemento exclusivo para o preenchimento do vazio existencial. Além disso, ECP recobre seu discurso com temas que enfatizam a divergência entre amor carnal e amor espiritual, revelando um narrador que passa pelas ruínas da frustração amorosa causadas pela repressão sexual (“apesar das ruínas e da morte/ onde sempre acabou cada ilusão”) para chegar ao amorpaixão. Ou, do ponto de vista mais histórico, ECP nos faz refletir, por meio dos temas e figuras que convoca, sobre essa transformação histórica pela qual passou a sociedade ocidental cristã: "O que se assistiu ao longo dos tempos, foi uma longa evolução que passou da proibição do prazer ao direito ao prazer" (PRIORE, 2007, p. 133).

\subsection{O Rio/ Francisco, Francisco}

O Rio / Francisco Francisco fez parte do repertório do CD dentro do mar tem rio, lançado ao vivo, no ano de 2007, como resultado do show apresentado no Canecão (Rio de Janeiro), nos dias 18 e 19 de agosto.

\subsubsection{Análise do poema $O$ Rio}

João Cabral de Melo Neto, autor do poema em foco, nasceu em 9 de janeiro de 1920, no Recife, e faleceu em 12 de outubro de 1999, no Rio de Janeiro. A exemplo de Vinicius de Moraes e João Guimarães Rosa, também foi diplomata. "Em 1953, vivendo no Rio de janeiro, Cabral escreve o poema 'O rio' - publicado no ano seguinte - e trabalha nos jornais Vanguarda e Última hora" (MENEZES, 2011, p. 112). Esse poema, intitulado, para sermos mais exatos, $O$ rio ou Relação da viagem que faz o Capibaribe de sua nascente à cidade do Recife foi inscrito no Concurso Literário do IV Centenário de São Paulo, tendo recebido o primeiro lugar (MENEZES, 2011, p. 143). 
Ressaltamos que o poema possui uma extensão de aproximadamente 25 páginas, o que nos levou a optar pela citação e pela análise apenas da primeira estrofe, pertencente à parte intitulada Da lagoa da Estaca a Apolinário. É dessa estrofe que Maria Bethânia "recortou" os oito primeiros versos para gerar sua canção-poema. Segue a referida estrofe:

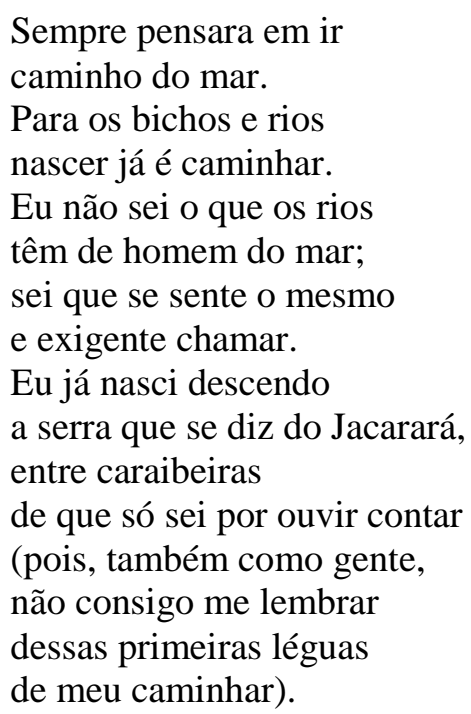

(MELO NETO, 1953/2008, p. 95)

O primeiro tema que destacamos, nesse poema, é a origem da vida, que pode ser apreendido por meio das figuras reunidas nos trechos: "Para bichos e rios/ nascer já é caminhar", "Eu já nasci descendo/ a serra que se diz do jacarandá”. Outro percurso temáticofigurativo vem sobrepor-se a ele: o da migração, presente em figuras como "ir, "caminho do mar", "caminhar", "homem do mar", "exigente chamar". Ressaltamos aqui a ênfase dada ao rio enquanto migrante, embora essa caracterização valha também para os bichos e para os homens (do mar).

A comparação narrador/homem do mar/rios vista, por exemplo, nos trechos: "Sempre pensara em ir / caminho do mar e "Eu não sei o que os rios têm /de homem do mar; sei que se sente / o mesmo e exigente chamar." permite reler a migração como predestinação para migrar. Em outras palavras: homens, bichos e rios são impelidos, desde o seu nascimento/origem, ao caminhar para sobreviver, o que revela uma certa cumplicidade, já que eles caminham juntos. O trajeto do rio equipara-se, desse modo, ao trajeto de homens e bichos, desde a origem. Em suma, EP põe em evidência, em seu contrato enunciativo, a cumplicidade da migração entre homens, bichos e rios para a garantia da sobrevivência. Tal posicionamento enunciativo condiz, inclusive, com posicionamentos discursivos presentes em outros poemas cabralinos, o que levou Menezes (2011, p. 153) a afirmar que 
Ao acolher em sua escritura imagens relacionadas ao cortador de cana, ao trabalhador do engenho, ao migrante, ao pária, Cabral efetua um posicionamento ético-político. O poeta apresenta não apenas o corpo abandonado e sem perspectiva de melhorias das condições existenciais, mas também saberes periféricos, laços culturais e comportamentos nem sempre capturados pelos dispositivos de enquadramento social.

Em outros termos, o tema da migração, presente no poema, aponta para outro tema: o engajamento político do EP, tema que, de acordo com a citação de Menezes (2011), manifesta-se em boa parte da obra do poeta pernambucano. Vale destacar que, nessa primeira estrofe, que será, em parte, retomada por Maria Bethânia, esse tema passa quase despercebido, principalmente, pela omissão da causa da migração e também pelo fato de o foco da migração estar no Rio ${ }^{46}$, e não nos homens.

\subsubsection{Análise da canção Francisco, Francisco}

Trata-se de uma composição de Roberto Mendes e José Carlos Capinan. O primeiro é cantor e compositor; o segundo exerceu as profissões de publicitário, jornalista e médico, além de ser poeta, letrista e escritor ${ }^{47}$. Reproduzimos, a seguir, a letra da canção. Nesse caso, optamos pela referência à interpretação do próprio Roberto Mendes numa participação especial no disco Salve São Francisco, de Geraldo Azevedo, cujo lançamento ocorreu posteriormente a dentro do mar tem rio.

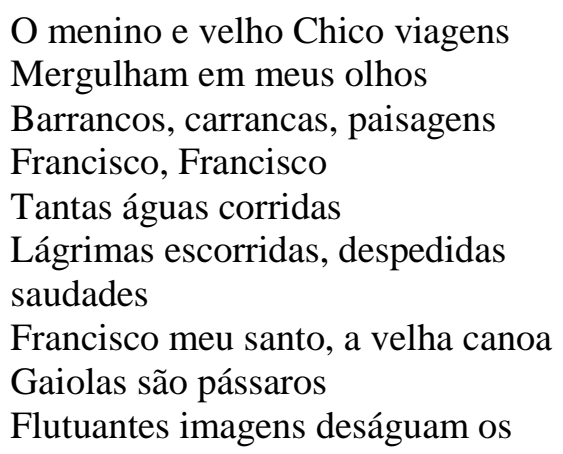

\footnotetext{
${ }^{46} \mathrm{O}$ fato de o foco da migração (no sentido de ir de um lugar a outro) estar no Rio é um caso que mereceria mais atenção, sobretudo porque a leitura integral do poema revela a importância desse foco, mostrando um engajamento social, mas sob o ponto de vista estético. Dada a extensão do poema, como já foi apontado, e os limites de tempo-espaço de uma dissertação de mestrado, não abordaremos essa questão. Vale a pena, no entanto, conferir alguns versos do final do poema: “(...) A um rio sempre espera/ um mais vasto e ancho mar. /Para a gente que desce/ é que nem sempre existe esse mar,/ pois eles não encontram /na cidade que imaginavam mar/ senão outro deserto/ de pântanos perto do mar (...)" (Ver MELO NETO, 1953/2008, p. 118).

${ }^{47}$ Dados disponíveis em: www.dicionariompb.com.br. Acesso em 26 jan. 2013.
} 
Instantes

$\mathrm{O}$ vento e a vela

Me levam distante

Adeus velho Chico

Diz o povo nas margens

(MENDES; CAPINAN, 2011, Faixa 6)

O primeiro tema que destacaremos nessa canção é a inexorabilidade do deslocamento, o que está subjacente a "O menino e velho Chico viagens". Nesse caso, as figuras escolhidas pelo EC mostram o tempo incoativo (menino) e o tempo terminativo (velho) relativos à movimentação do rio São Francisco, que se articula à própria movimentação do narrador-personagem: “O vento e a vela/ Me levam distante.”.

Assim, se o tema da migração também se encontra presente, como no poema de João Cabral de Mello Neto, o realce aqui, no entanto, é para o homem migrante (não para o rio). Ao realçar o tema migração como migração humana, o EC evidencia o tema da despedida ou, melhor, da separação entre o migrante e seus conterrâneos, como podemos ver em "Tantas águas corridas/ lágrimas escorridas, despedidas/ saudade”.

Assim, podemos dizer que o contrato enunciativo proposto pelo EC volta-se para o tema da migração nostálgica, uma vez que a separação do migrante de sua terra natal é vista também como a perda das relações com o outro (incluindo os costumes, hábitos etc. adquiridos numa dada região).

\subsubsection{Análise de $O$ Rio/ Francisco, Francisco: um terceiro texto}

Essa canção-poema fez parte do disco dentro do mar tem rio. Antes de citá-la, ressaltamos que esse trabalho estava relacionado ao show de lançamento simultâneo dos discos Maria Bethânia Pirata (BETHÂNIA, 2006a) e Maria Bethânia Mar de Sophia (2006b). Fato relevante e que reafirma o nosso posicionamento frente à junção de poemas e canções como um terceiro texto, é que essa canção-poema que analisamos no disco ao vivo encontra-se também no disco de estúdio Maria Bethânia Pirata; na realidade, não apenas essa canção-poema como outras hibridizações que não estamos examinando no presente trabalho. 
Além disso, houve uma particularidade nessa canção-poema que merece ser comentada: Maria Bethânia, em dentro do mar tem rio, ao interpretar a canção Francisco, Francisco, citou uma canção de domínio público, que é Meu divino são José. Esta, no disco de estúdio, Maria Bethânia Pirata, encontra-se numa faixa posterior, imbricada com um texto de Guimarães Rosa. Para esta análise, valemo-nos da primeira ocorrência apenas, ressaltando que, no encarte do $\mathrm{CD}$ dentro do mar tem rio, não há as letras das canções, apenas suas fontes. Na realidade, a intérprete optou por apresentar apenas a letra da canção agora, de Tony Bellotto, Charles Gavin, Branco Mello, Nando Reis, Marcelo Fromer, Paulo Miklos, Sérgio Britto e Arnaldo Antunes (ou seja, de autoria do grupo brasileiro Titãs) no encarte desse CD. Sobre o poema, ela não citou a estrofe inteira, apenas o primeiro trecho, ou seja, os oito primeiros versos:

Sempre pensara em ir caminho do mar.

Para os bichos e rios nascer já é caminhar. Eu não sei o que os rios têm de homem do mar; sei que se sente o mesmo e exigente chamar.

O menino e velho Chico viagens Mergulham em meus olhos Barrancos, carrancas, paisagens

Francisco, Francisco

Tantas águas corridas Lágrimas escorridas, despedidas saudades Francisco meu santo, a velha canoa Gaiolas são pássaros Flutuantes imagens deságuam os Instantes $\mathrm{O}$ vento e a vela Me levam distante Adeus velho Chico Diz o povo nas margens

Meu divino São José Aqui estou a vossos pés Dai-nos chuva com abundância Meu divino São José (BETHÂNIA, 2007, Faixas 19-20) 
Ao incorporar o trecho do poema de João Cabral à letra da canção, ECP coloca em evidência o tema da migração nostálgica, não apenas do ponto de vista do migrante enquanto homem, mas também do ponto de vista do migrante enquanto o próprio rio. Com isso, o tema da cumplicidade entre homens, bichos e rios, revelado no poema de forma isolada, é parcialmente quebrado. Isso porque "o vento e a vela" levam apenas o narrador, deixando o povo à margem.

Assim, o tema da despedida passa a ser visto praticamente como o abandono dos conterrâneos, pois, se a migração é uma predestinação para homens, bichos e rios para garantir sua sobrevivência, ECP mostra que há um povo que não migra (mas que tem a necessidade de migrar), aquele que fica à margem, não cumprindo, portanto, o seu destino. Junte-se a isso o tema da inexorabilidade do deslocamento (visto anteriormente na análise da canção de forma isolada). Porém, o que o ECP realça é o fato de as viagens serem sempre de ida: "Sempre pensara em ir / caminho do mar". Embora essa ida se estenda a bichos, rios e homens (estes representados, metonimicamente, pelo narrador migrante), o que ECP enfatiza é o fato de o rio estar seguindo o seu destino de migrar e, dessa forma, deixando para trás aqueles que não puderam acompanhá-lo.

Esse último fato sugere o tema da "escassez de água na região semiárida nordestina” (MENDONÇA; BARBOSA JÚNIOR, 2010, p. 87), ou, simplesmente, seca. O que nos levou a postular a presença desse tema foi a análise do trecho: "Sempre pensara em ir", "Tantas águas corridas/ Lágrimas escorridas", “Adeus velho Chico/ Diz o povo nas margens". Além disso, destacamos a citação da canção Meu divino São José, na qual vemos esse tema nitidamente "Meu divino São José/ Aqui estou a vossos pés/ Dai-nos chuva com abundância/ Meu divino São José".

Portanto, ECP partilha com o seu enunciatário uma visão de mundo em que se destacam as implicações do meio ambiente na/para a vida humana, formação ideológica presente em textos como o que segue:

Conforme Relatório de Impacto Ambiental do Projeto de Integração do Rio são Francisco com as Bacias Hidrográficas do Nordeste Setentrional - RIMA, elaborado em julho de 2004, o referido Projeto objetiva, à primeira vista, a busca de soluções para os graves problemas acarretados pela escassez de água na região, os quais estariam inviabilizando a sobrevivência em condições dignas das populações afetadas. Destaca-se assim a necessidade de se oferecer a todos o acesso à água (MENDONÇA; BARBOSA JUNIOR, 2010, p.88). 
A diferença é que, enquanto o trecho acima é articulado com o discurso político, a canção-poema está articulada com o discurso literário. ECP mostra, então, que a arte também pode abordar problemáticas de cunho social, sem, contudo, perder sua finalidade estética.

Para finalizar, apresentamos, no quadro a seguir, uma síntese das análises empreendidas. Esse quadro servirá de base para as questões de éthos, estilo, autoralidade e gêneros do discurso, que serão discutidas no próximo capítulo: 


\begin{tabular}{|c|c|c|c|}
\hline Canções-poemas & Enunciador do poema & Enunciador da canção & Enunciador da canção-poema \\
\hline Eros e Psique/ Tigresa & $\begin{array}{l}\text { Descrença na busca do amor; FI } \\
\text { machista. }\end{array}$ & $\begin{array}{l}\text { Defesa do feminismo, atrelado, } \\
\text { sobretudo, à liberação sexual da } \\
\text { mulher. }\end{array}$ & $\begin{array}{l}\text { Reivindicação da igualdade } \\
\text { entre os sexos, com ênfase na } \\
\text { gradual defesa dos direitos } \\
\text { (privados e públicos) da mulher. }\end{array}$ \\
\hline $\begin{array}{l}\text { O poeta come amendoim/ Canto } \\
\text { do Pajé }\end{array}$ & $\begin{array}{l}\text { Reconstrução do conceito de } \\
\text { patriotismo: deve-se amar a } \\
\text { pátria por ser o que é }\end{array}$ & $\begin{array}{l}\text { Desativação da figura do índio } \\
\text { como símbolo nacional; FI do } \\
\text { direito inalienável do índio à } \\
\text { terra. }\end{array}$ & $\begin{array}{l}\text { Ênfase no tema da mestiçagem, } \\
\text { com o surgimento da FI que } \\
\text { reconhece a necessidade de o } \\
\text { Estado assegurar a todos os } \\
\text { cidadãos brasileiros, } \\
\text { indistintamente, o acesso à } \\
\text { terra. }\end{array}$ \\
\hline $\begin{array}{l}\text { Pátria minhal } \\
\text { Melodia sentimental }\end{array}$ & $\begin{array}{l}\text { (In)definição subjetiva de } \\
\text { pátria; Forma peculiar de amor } \\
\text { intimista (incondicional) à } \\
\text { pátria: amá-la não é exaltar } \\
\text { símbolos nacionais, é amá-la } \\
\text { como se ela fosse uma mulher. }\end{array}$ & $\begin{array}{l}\text { Valorização do amor puro entre } \\
\text { dois seres humanos, com } \\
\text { destaque para os temas da } \\
\text { ternura, da fidelidade e do } \\
\text { desejo. }\end{array}$ & $\begin{array}{l}\text { Visibilidade da pátria enquanto } \\
\text { mulher amada, merecedora de } \\
\text { uma exaltação amorosa, } \\
\text { declarada publicamente; ênfase } \\
\text { nos temas da afetividade e da } \\
\text { transparência. }\end{array}$ \\
\hline $\begin{array}{l}\text { Poema do menino Jesus/Doce } \\
\text { mistério da vida }\end{array}$ & $\begin{array}{l}\text { Valorização do mundo natural; } \\
\text { presença de determinações } \\
\text { ideológicas antirreligiosas e } \\
\text { antifilosóficas que se opõem, } \\
\text { portanto, às verdades universais, } \\
\text { inquestionáveis. }\end{array}$ & $\begin{array}{l}\text { Valorização da espiritualidade } \\
\text { (não de uma religião } \\
\text { institucionalizada), numa } \\
\text { perspectiva que beira o } \\
\text { filosófico. }\end{array}$ & $\begin{array}{l}\text { Reconhecimento de algo de } \\
\text { procedência sobrenatural no } \\
\text { viver do homem; valorização da } \\
\text { espiritualidade, sem que haja a } \\
\text { ridicularização de dogmas e } \\
\text { figuras da igreja católica. }\end{array}$ \\
\hline $\begin{array}{l}\text { Aniversário/ Uma canção } \\
\text { desnaturada }\end{array}$ & $\begin{array}{l}\text { Constatação da existência da } \\
\text { vida apenas na infância. Após } \\
\text { essa fase da vida, resta apenas a } \\
\text { solidão, a sobrevida. }\end{array}$ & $\begin{array}{l}\text { FI feminista com ênfase no } \\
\text { individualismo da mulher como } \\
\text { responsável pela decisão de ser } \\
\text { (ou não) mãe; não idealização } \\
\text { da infância, sobretudo no que } \\
\text { diz respeito à criança de sexo } \\
\text { feminino. }\end{array}$ & $\begin{array}{l}\text { Ênfase nos temas do egoísmo, } \\
\text { do aborto e do feminismo, numa } \\
\text { espécie de releitura da infância, } \\
\text { vista sob a ótica da mulher/mãe; } \\
\text { Ser sujeito de si mesmo é opor- } \\
\text { se a determinações ideológicas, } \\
\text { principalmente políticas, } \\
\text { assumidas, em geral, sem } \\
\text { discussão ou questionamento. }\end{array}$ \\
\hline $\begin{array}{l}\text { E depois de uma tardel Amor de } \\
\text { Índio }\end{array}$ & $\begin{array}{l}\text { Reconhecimento da necessidade } \\
\text { de sonhar, apesar das } \\
\text { dificuldades e obstáculos } \\
\text { impostos pelo mundo que nos } \\
\text { rodeia. }\end{array}$ & $\begin{array}{l}\text { Defesa do prazer como direito } \\
\text { dos amantes, enfatizando o } \\
\text { reconhecimento do amor-paixão } \\
\text { como realização sagrada. }\end{array}$ & $\begin{array}{l}\text { Preenchimento do vazio } \\
\text { existencial exclusivamente pelo } \\
\text { amor-paixão, evidenciando a } \\
\text { evolução da sociedade ocidental } \\
\text { cristã em relação à } \\
\text { privação/direito ao prazer. }\end{array}$ \\
\hline O Rio/ Francisco, Francisco & $\begin{array}{l}\text { Cumplicidade da migração entre } \\
\text { homens, bichos e rios (com } \\
\text { ênfase nestes) para garantir a } \\
\text { sobrevivência. }\end{array}$ & $\begin{array}{l}\text { Migração nostálgica, em que o } \\
\text { migrante (homem) perde parte } \\
\text { de suas relações com o outro } \\
\text { (incluindo costumes, hábitos, } \\
\text { etc., adquiridos numa dada } \\
\text { região). }\end{array}$ & $\begin{array}{l}\text { Implicações do meio ambiente } \\
\text { na/para a vida humana; } \\
\text { evidência de problemáticas } \\
\text { sociais, sem perder, contudo, a } \\
\text { finalidade estética. }\end{array}$ \\
\hline
\end{tabular}




\title{
CAPÍTULO 3: ÉTHOS, ESTILO, AUTORIA E GÊNEROS DE DISCURSO
}

\author{
"É a nossa sorte: nós, artistas de tradição ibérica, podemos recorrer a \\ essa mistura de popular e erudito, que vem das fontes." (JOÃO \\ CABRAL DE MELO NETO, 2008, p. 23) \\ "A citação é contato, fricção, corpo a corpo; ela é o ato que põe a mão \\ na massa de papel." (ANTOINE COMPAGNON,1996 p. 36)
}

No capítulo precedente, constatamos, via exame dos temas e figuras mais relevantes, a emergência de um novo texto (a canção-poema, ligada, portanto, a ECP) diferente dos textos ligados aos gêneros canção e poema quando tomados isoladamente (e relacionados, portanto, a EC e a EP).

Veremos agora como as análises realizadas contribuem para desvelar questões relacionadas ao éthos, ao estilo, à autoria e algumas problemáticas sobre a noção de gênero de discurso. Passemos, então, à analise do éthos de Maria Bethânia.

\subsection{Análise do éthos da intérprete Maria Bethânia}

Cabe lembrar aqui que a visão de mundo do enunciador está atrelada aos temas e figuras que seu(s) texto(s) deixa(m) entrever, o que lhe permitirá, em última análise, construir uma "maneira de dizer" que remete a uma "maneira de ser", o que está relacionado ao éthos, ou seja, à imagem que o orador dá de si mesmo aos outros. Nessa perspectiva, ao retomarmos a visão de mundo do enunciador de cada uma das sete canções-poemas analisadas, tomandoas como exemplificação de uma totalidade discursiva (a obra completa de Maria Bethânia), poderemos chegar ao éthos da intérprete.

Retomando o quadro-síntese do final do capítulo 2, verificamos uma posição constante da enunciadora Maria Bethânia (vista como um sujeito inscrito no discurso das canções-poemas). Trata-se da projeção de uma imagem de um sujeito que propõe uma estratégia de complementaridade entre os gêneros poema e canção num mesmo espaço 
textual. Tal complementaridade está relacionada a estratégias de mobilização discursiva, em que ECP repete temas e figuras, mas inventa outros; reitera uma posição discursiva, mas rompe parcial ou integralmente com ela, alargando ou restringindo o contrato enunciativo do poema e da canção analisados de forma independente.

Em suma: a ocorrência dessas estratégias deve-se, principalmente, à manipulação que ECP faz dos temas e figuras, reenquandrando-os em novos percursos temático-figurativos inscritos, em geral, em outras determinações ideológicas, distintas das inicialmente apresentadas. É isso que as análises realizadas demonstram e que resumimos no quadro anteriormente apresentado. Isso nos permite antever um éthos de competência e autonomia, que permite à ECP transitar por diferentes textos e gêneros e mobilizar autores os mais diversos para construir "seu" próprio texto. E mais: leva à imagem de um sujeito "eruditocarnavalesco $^{48}$ ", evidenciando que, em termos de proposta de significação, os gêneros poema (mais erudito) e canção (mais popular) podem aproximar-se e ganhar a adesão do enunciatário, que, assim, valorizará não apenas esses dois gêneros discursivos de forma isolada, mas também a prática discursiva de sua junção, de modo a originar um terceiro texto (híbrido).

Essa valorização simultânea de gêneros que podem ser vistos, originalmente, como práticas sociais bastante distintas - como sugere a oposição erudito/popular, em que o poema é tomado como uma prática intelectualizada e a canção, como produto exclusivo de uma sociedade de consumo - merece uma atenção maior.

Usamos o termo "erudito-carnavalesco" para caracterizar uma das vertentes do éthos de Maria Bethânia, enfatizando que, na sua estratégia de complementaridade textual, há um jogo dialógico entre o erudito e o popular, sem que se hierarquizem os gêneros poema e canção. Isso pode ser visto na própria diversidade de autores mobilizados por ela, como já foi dito.

\footnotetext{
${ }^{48}$ Ressaltamos que a definição de erudição, em termos de dicionário, e por isso mesmo de algo mais presente no imaginário social, é "instrução, conhecimento ou cultura variada, adquiridos, esp. por meio da leitura" (cf. HOUAISS; VILLAR, 2009, p. 790). Já o termo carnavalização está sendo empregado no sentido bakhtiniano (1997, p. 101-180). Bakhtin retoma a ideia fundamental de carnaval, a de "festa que tudo destrói e tudo renova" e transpõe essa linguagem para a literatura, chamando de carnavalização da literatura a combinação de vários elementos heterogêneos, como por exemplo, o diálogo filosófico, a aventura do fantástico, do naturalismo, da utopia etc. unidos num "todo orgânico do gênero" (BAKHTIN, 1997, p. 135). No caso da imagem projetada por Maria Bethânia, utilizamos o termo justamente para mostrar a "destruição" e a "renovação" das regras impostas para um sujeito se constituir como "erudito", quase sempre se contrapondo ao "popular".
} 
Tomando os autores dos poemas e das canções aqui analisados como exemplos dessa diversificação, vemos que os poetas Fernando Pessoa, Mario de Andrade, Vinícius de Moraes, Alberto Caeiro, Álvaro de Campos, Sophia de Melo Breyner Andresen e João Cabral de Melo Neto já nos dão uma primeira ideia dessa carnavalização no próprio gênero poema. Primeiro, pela mistura entre a literatura portuguesa e a brasileira. Segundo, pela seleção de autores que contribuíram para a literatura em momentos distintos e de formas diversas.

Ocorre o mesmo processo de carnavalização no caso das canções: Caetano Veloso, Heitor Villa Lobos e C. Paula Barros, Villa Lobos e Dora Vasconcelos, Victor Herbert, Chico Buarque, Beto Guedes e Ronaldo Bastos, Roberto Mendes e José Carlos Capinan permitem constatar a valorização do gênero canção como um todo, a partir do reconhecimento da diversidade da arte cancioneira.

É importante notar que essa questão (junção ou separação) entre o erudito e o popular já vem sendo discutida há algum tempo. Para retomar alguns aspectos dessa problemática, vamos recorrer a este trecho de uma entrevista, em que Chico Buarque posiciona-se sobre o tema:

Chico: "Isso é muito peculiar da música popular brasileira e é alguma coisa notável,
porque essa barreira entre erudito e popular não é tão evidente para nós quanto é na
Europa, principalmente na França e na Itália. Lá a canção popular está relegada, com
pouquíssimas exceções, a um submundo artístico. É considerada um produto
industrial/comercial e ponto. Não há nenhuma veleidade cultural em fazer música
popular. Você passa de um campo para o outro com mais facilidade. Os
compositores e os músicos também tinham uma carga de informações, inclusive
erudita, maior, e só presente na bossa nova, que não existe na Europa" (BUARQUE
apud NAVES, 2006, p.167).

Embora concordemos parcialmente com o que foi exposto por Chico Buarque, gostaríamos de fazer uma ressalva: a barreira entre o erudito e o popular pode até não ser tão evidente em nosso país, porém algumas práticas discursivas necessárias à produção e à circulação dos gêneros canção e poema parecem indicar uma posição contrária, levando-se em conta o imaginário social.

Se nos atentarmos para duas questões levantadas a partir da leitura de um trecho do prefácio escrito por Magda Soares no livro O professor e a literatura (2009), de Ligia Cademartori, veremos qual é a problemática envolvida. 
Porque Ligia escreve não do lugar da especialista em literatura, embora ela o seja, não do lugar da formadora de leitores, embora ela o seja, mas do lugar da leitora apaixonada por leitura que ela é, e, por sê-lo, sabe que não é contando aos professores a história da literatura infanto-juvenil, ou aconselhando sobre o que fazer para transformar crianças e jovens em leitores, que professores despertarão o gosto e o prazer de ler em seus alunos... (SOARES apud CADEMARTORI, 2009, p. 13).

O que nos chamou a atenção nesse excerto foi a diferença entre aconselhar ou fazer com que outros sujeitos exerçam a leitura e ser leitor(a). Ao que parece, a adesão a um dado texto será mais eficiente quando o enunciador mostrar-se também leitor. É justamente isso que Maria Bethânia faz em suas canções-poemas: ela mostra ao enunciatário a significação da leitura em sua proposta estética, evidenciando que ler lhe permite apreender outros textos e transformá-los, ressignificá-los, enfim, como leitora que é.

Assim, além dos éthe de competência, autonomia e de um sujeito "eruditocarnavalesco", ECP, que coincide com a intérprete Maria Bethânia, mostra também um éthos de leitor, que contribui para a adesão do enunciatário ao seu discurso. Trata-se aqui não do éthos dito (as informações que ECP poderia dar de si mesma), mas do éthos mostrado, que se relaciona, sobretudo, às escolhas que faz (dos textos, dos autores, dos temas etc.) e às estratégias que mobiliza para levar o enunciatário das canções-poemas a aceitar a junção de dois gêneros que, em princípio, não se enquadram da mesma maneira no domínio discursivo literário, como já pontuamos. Essa questão será desenvolvida com mais ênfase no subitem destinado às problemáticas que envolvem os gêneros discursivos. Antes, porém, vamos aos desdobramentos das análises feitas para as problemáticas ligadas às noções de estilo e de autoria.

Uma última observação: a ressignificação que Bethânia faz das canções e dos poemas, em suas canções-poemas, mostra ainda o éthos de um sujeito politicamente engajado, comprometido com as minorias, haja vista a inscrição desses novos textos em formações ideológicas como a feminista, a do direito inalienável à terra etc. Isso, por outro lado, vai contribuindo, ao longo do tempo, para a construção do éthos prévio de Maria Bethânia. Assim, antes mesmo que ela "abra a boca", o enunciatário já cria expectativas relacionadas à presença de canções-poemas na discografia da intérprete, à mobilização de temas engajados, etc. 


\subsection{Análise do estilo nas canções-poemas da intérprete Maria Bethânia}

Discorrer sobre o estilo não é tarefa simples. Ao contrário, há que se refletir sobre vários aspectos que influenciam as particularidades dos textos de um dado autor, que são reiteradas ao longo de sua trajetória, constituindo, pois, sua proposta estética. Assim, sabemos que nossa contribuição é parcial, pois estamos mostrando apenas um dos muitos recursos utilizados por Maria Bethânia para construir seu próprio estilo.

Ao mostrar-se um sujeito erudito-popular, Maria Bethânia manipula os gêneros canção e poema e, na medida em que faz isso, constrói isotopias (planos de leitura) não presentes nos discursos de EC e EP, quando tomados isoladamente, ou seja, ela absorve temas e figuras dos textos originais, mas também cria novos. Assim, ao persuadir o outro por meio do recurso de hibridização de gêneros num mesmo espaço textual, ECP acaba por mostrar a complementaridade de tais gêneros e mais: revela um estilo peculiar, pois evidencia, de certa forma, o avesso do que se poderia considerar o "estilo" de um intérprete.

Expliquemos: no caso de intérpretes/cantores de MPB, o mais comum é que ocorra apenas (ou que sobressaia apenas) a exploração de recursos de técnica vocal (relacionados, portanto, ao plano de expressão). Bethânia, porém, além de se valer desses recursos, também age sobre o plano de conteúdo dos textos, no nosso caso, sobre as letras das canções, relendo-as e modificando-as à sua maneira. Aliás, o surgimento do contrato enunciativo de ECP é fundamental para a construção do estilo das canções-poemas, pois

\footnotetext{
(...) o estilo artístico não trabalha com as palavras, mas com os componentes do mundo, com os valores do mundo e da vida; podemos defini-lo como o conjunto dos procedimentos de formação e acabamento do homem e do seu mundo, e esse estilo determina também a relação com o material, com a palavra, cuja natureza deve, naturalmente, ser conhecida para se compreender essa própria relação (BAKHTIN, 2003, p. 208-209).
}

Nesse sentido, a releitura feita pela intérprete de parte da obra de autores/poetas brasileiros e portugueses é notável. Embora se trate de uma prática frequente, vemos que essa frequência, está, em geral, atrelada a outros papeis sociais, como os de escritor, poeta, compositor etc., não ao de uma cantora/intérprete de música popular (brasileira). Assim, no estilo bethâniano de interpretar canções, sobressai uma prática textual-discursiva já amplamente utilizada em outros gêneros literários - como contos, romances, poemas, teatro 
etc. -, mas ainda incipiente no âmbito da interpretação de canções da MPB. A intérprete, portanto, desloca tal prática e a problematiza.

\subsection{Análise em torno da noção autor ou autoralidade}

Se a junção entre poemas e canções suscita novos sentidos por meio de novos percursos temático-figurativos, construídos, inclusive, com base num estilo próprio, não podemos negar que há a criação de um terceiro texto, tomado como uma (nova) unidade de sentido. É, em linhas gerais, o que ocorre com as canções-poemas de Maria Bethânia. Através da estratégia de complementaridade textual, a enunciadora mostra o funcionamento da canção-poema como um todo significativo, que é gerado por meio de mecanismos próprios, aqui exemplificados pela mobilização de temas e figuras. Tudo isso voltado para a adesão do enunciatário.

Assim, ao postularmos que a canção-poema é um texto único, temos que considerar a questão da autoralidade, visto que, como já havíamos salientado, "todo texto implica certa autoralidade, e o modo de onde emerge o texto implica ele próprio essa forma de autoralidade" (MAINGUENEAU, 2010, p. 46). Para isso, a análise da autoralidade será feita com base nas imagens do autor, levando em conta sua condição de instância híbrida: de um lado, retomaremos alguns pontos do éthos da enunciadora Maria Bethânia, de outro, abordaremos alguns aspectos do estatuto social do sujeito Maria Bethânia.

No que concerne ao éthos discursivo, vimos que a intérprete possui um éthos predominante de sujeito erudito-popular, na medida em que adota uma estratégia de complementaridade textual entre os gêneros poema e canção numa proposta própria (num "estilo" próprio) de significação. Isso nos leva a acrescentar que se trata de uma imagem de "erudita-carnavalesca" com dimensões autorais, entendidas aqui como pertencentes a uma auctora, no sentido atribuído ao termo por Maingueneau (2010, p. 33). De acordo ele, o termo auctor deve ser usado como correlato de uma obra, sendo que "obra, um Opus é, com efeito, tido como algo que 'exprime' a personalidade singular de seu autor".

Precisamos, agora, compreender os conceitos tanto de auctor, quanto de Opus, do ponto de vista da produção da canção popular brasileira, considerando que Maria Bethânia é, antes de tudo, uma cantora/intérprete (até por essa razão usamos o termo 'canção-poema' e não o contrário). Entendemos que a diferenciação entre os papéis sociais de cantor/intérprete, 
compositor e letrista pode contribuir para uma distinção das dimensões auctorais da canção. Nesse gênero, a questão da autoralidade parece ser mais complexa, o que compromete a implicação de terceiros no reconhecimento da obra. Poderíamos, assim, pensar numa gradação na constituição plena de um auctor, como observa Maingueneau (2010, p. 32):

\begin{abstract}
Para ser plenamente auctor, é preciso ser reconhecido, ter uma 'imagem de autor'. O grau desse 'reconhecimento' varia com a natureza dos terceiros implicados. Uma coletânea de poesias publicada por conta do autor e da qual só a família e os amigos próximos do produtor falam confere uma qualidade de 'auctor' de nível bem baixo; ao contrário, um ensaio publicado por um grande editor, citado por diversas revistas de prestígio e que leva seu autor a um programa de televisão, confere um forte coeficiente de "autoralidade".
\end{abstract}

Essa diferença gradativa relacionada à noção de auctor é relevante, e como podemos ver, ela se ampara no papel social, no caso, o de editor. Nossa hipótese é a de que os papéis sociais envolvidos na produção da canção possuem uma dimensão de auctoralidade, que, no entanto, é variável. Defenderemos aqui três dimensões.

A primeira dimensão é a do auctor correlativo a um opus, em que a instância enunciativa, embora possa ser dividida, sobretudo, metodologicamente, confunde-se na hora de seu "reconhecimento" por terceiros. Quando se fala, por exemplo, da obra de artistas como Caetano Veloso, nem sempre fica claro a qual "obra" se está referindo. Trata-se de suas composições ou de suas interpretações? Nesse caso, defendemos que, no gênero discursivo canção, deveria ser empregado o termo auctor de nível intérprete-composicional ${ }^{49}$ para os casos de autoria da canção (letra e música) e de sua interpretação. Nesse caso, os papéis sociais de compositor e intérprete são exercidos concomitantemente, ou melhor, estão sincretizados em um mesmo sujeito.

Sabemos, porém, que a produção de uma canção pode envolver compositores (da melodia) e letristas. Nesse caso, deveríamos reservar o termo auctor de letras de música lauctor letrista ${ }^{50}$ para as letras das canções. Cabe questionar se o papel social de letrista chama a mesma atenção de terceiros que os anteriores. Na última citação de Maingueneau (2010), vimos o quão importante é a influência da mídia e de especialistas sobre o grau da auctoralidade. Parece-nos que, em casos da música popular brasileira, o mais frequente é a

\footnotetext{
${ }^{49}$ É importante esclarecer que, embora essa nomenclatura possa soar semelhante ao conceito de "autor-ator" (cf. MAINGUENEAU, 2010, p. 30), acreditamos que, pelo fato de nessa segunda dimensão da noção de autor proposta pelo teórico francês não haver correlatividade com o $O p u s$, ela não seria adequada.

${ }^{50}$ Não abordaremos o caso da autoria da melodia (ou seja, da parte musical), uma vez que ela coloca problemas de outra ordem que fogem ao escopo do presente trabalho. Esclarecemos ainda que, quando se tratar do compositor da letra, usaremos o termo letrista, para distingui-lo do compositor da melodia, a que, para simplificar, chamaremos simplesmente de compositor.
} 
aparição de cantores e/ou compositores em meios midiáticos. Entretanto, o entendimento especializado sobre a canção ultrapassa, a nosso ver, os casos midiáticos não especialistas, em termos de análise da auctoralidade.

É preciso esclarecer que não estamos entendendo por obra algo necessariamente materializado. Ou seja, não importa se há um livro com as letras de música feitas, por exemplo, por Ronaldo Bastos (letrista, como vimos, da canção Amor de Índio). O relevante é seu reconhecimento como auctor de textos correlacionados a um Opus, já que grande parte dos letristas são reconhecidos/valorizados por suas criações, levando-se em conta tanto o plano do conteúdo (as ideias veiculadas) quanto o plano de expressão da parte verbal da canção (rimas, jogos sonoros: aliterações, assonâncias etc.).

A última classificação que propomos para a noção de auctor, no caso do gênero canção, é a de auctor intérprete, reservado, como se vê, ao papel social de intérprete/cantor. Aqui, a correlação com a obra incidiria apenas sobre a referência à discografia dos intérpretes/cantores ao longo de sua trajetória. Entretanto, há algo que distingue o grau de auctoralidade do intérprete dos outros dois casos.

Admitimos, com Maingueneau (2010, p. 34), que "a noção de auctor implica certo 'ponto de vista', 'uma convicção', ‘uma visão de mundo... '”. É isso que, a nosso ver, distinguirá melhor cada um desses três tipos de auctores que propomos no âmbito do gênero canção. Nos dois primeiros tipos, o opus se inscreve numa "visão de mundo" relacionada ao “escrever” a canção, o que resulta de uma prática discursiva em que a importância do conteúdo verbo-musical $^{51}$ é uma proposta de significação de compositores e/ou letristas. Assim, os "pontos de vistas" da produção são aqueles relacionados a um saber fazer canção (música e letra) e/ou a um saber fazer letra.

Já no caso dos auctores intérpretes, a "visão de mundo" está inscrita na prática de cantar, isto é, os "pontos de vistas" da produção dos intérpretes estão relacionados a um saber interpretar. Com isso, a singularidade percebida por terceiros em relação a um Opus de uma intérprete está relacionado ao canto. Vejamos alguns dados sobre o assunto, retirados de Machado (2012), que, em sua tese de doutorado, pesquisou o canto popular brasileiro sob a ótica teórico-metodológica da Semiótica da Canção.

\footnotetext{
${ }^{51}$ É claro que a escolha do repertório de um intérprete tem implicações no conteúdo. Um exemplo, bastante frequente, é o eixo temático de um trabalho. Para citar casos da própria Maria Bethânia, ver Brasileirinho (2003) e dentro do mar tem rio (2007). Entretanto, trata-se de algo bem distinto do que ocorre com o conteúdo de canções, como foi descrito nos dois outros casos de auctor que propusemos.
} 
Sob a orientação de Luiz Tatit, Machado (2012) iniciou um processo analítico para a descrição do componente emotivo presente no canto. Um dado que revela a importância da distinção feita por nós entre auctor intérprete e auctor de nível intérprete composicional, é o seguinte: de acordo com Machado (2012, p. 27), no período da Bossa Nova, houve mudanças suscitadas por transformações vocais dentro desse movimento, originando, assim, os compositores-intérpretes. Para ela, isso resultou no surgimento do componente da dicção autoral, desprovido, no início, de um componente vocal de destaque. Percebemos, assim, que a importância dada ao auctor intérprete está mais relacionada às categorias do plano de expressão, visto que o que está em jogo são os destaques da voz dos intérpretes. O excerto que reproduzimos abaixo contribui para a manutenção da tripartição de auctores do gênero canção que estamos propondo:

\begin{abstract}
Considerando que a voz humana é o único instrumento capaz de realizar simultaneamente o texto linguístico e o texto musical, e sendo o núcleo de identidade da canção a relação entre esses dois componentes, compete à interpretação vocal o desenvolvimento das duas etapas existenciais subsequentes: a atualização e a realização. O sujeito configurado pelo compositor ganha, então, existência material além da letra, na própria melodia estabilizada pela voz do intérprete. Ou seja, a presença viva da voz atualiza o sujeito, corporificando sua existência numa outra dimensão. (...)

Ainda por intermédio da ação vocal, a produção de sentido extrapola os limites da letra e se reconfigura no gesto interpretativo, podendo mesmo trazer à luz significações expressas no plano de expressão linguística, bem como no plano de conteúdo do discurso musical (MACHADO, 2012, p. 44).
\end{abstract}

Vemos, então, que no caso das interpretações das canções, a outra dimensão significativa que deverá ser analisada está relacionada à presença viva da voz do intérprete. É a ação vocal deste que pode evidenciar significações tanto no plano de expressão linguística quanto no plano de conteúdo musical ${ }^{52}$. Entretanto, ressaltamos que no caso da expressão linguística, a possibilidade de análise é, por exemplo, vista sob o ponto de vista da articulação rítmica, em que "os tempos do discurso musical associado ao discurso linguístico" são usados para a construção de cada sílaba, cada palavra, cada frase e cada período para poder mostrar sua atuação na "construção de uma significação no campo extenso, mediante ações intensas" (MACHADO, 2012, p. 52).

\footnotetext{
${ }^{52}$ A questão do plano de conteúdo e do plano de expressão é mais complexa no caso de textos sincréticos aqueles expressos por pelo menos duas linguagens -, como é o caso da canção. Isto porque, no caso da letra, teríamos um plano de conteúdo verbal (as ideias veiculadas) e um plano de expressão verbal (em que são relevantes categorias como rima, entonação, jogos sonoros: aliterações, assonâncias etc.). Teríamos igualmente um plano de conteúdo e um plano de expressão sonoros (relacionados à melodia), que seriam, evidentemente, analisados por outras categorias, como, por exemplo, no caso do plano de expressão, tom (harmonia), pulso (ritmo) e frequência (cf. LOPES, 2003, p. 69). Nesta dissertação, conforme já foi explicado, privilegiamos apenas uma parte desse complexo processo: o plano de conteúdo verbal (letra).
} 
Um dos intérpretes escolhidos por Machado (2012) para a realização de seu trabalho foi exatamente Maria Bethânia, de quem a autora diz:

\begin{abstract}
Maria Bethânia, que inicialmente cria uma imagem de artista politizada pelo trabalho que realizou no espetáculo Opinião, consolidará no canto popular um lugar especial para a voz grave, de expressão direta e articulação rítmica capaz de particularizar suas interpretações, porque totalmente baseada na valorização expressiva da palavra e na construção de um fraseado rítmico dramatizado. Ao longo de sua carreira, Bethânia deixará cada vez mais clara a presença da fala teatralizada como elemento norteador de seu canto e consagrará a criação de uma dramaturgia para a realização do espetáculo musical. Seus shows, mais do que apresentar uma sequência de canções, viriam sempre estruturados por uma narrativa subjacente que orientava a construção do roteiro e para qual estavam voltados todos os elementos, dos arranjos à iluminação, dos figurinos à direção (MACHADO, 2012, p. 30).
\end{abstract}

Nesse fragmento podemos constatar que os elementos analisados em Maria Bethânia dizem respeito, sobretudo, ao plano de expressão musical. No entanto, como a própria autora sinaliza, tais recursos são articulados ao discurso linguístico (plano de expressão e plano de conteúdo). É o que ela mostra na canção É o amor, analisada em duas interpretações: a de Zezé di Camargo e a de Maria Bethânia. Sobre essa última, destacamos o trecho abaixo:

\footnotetext{
$\mathrm{Na}$ altura do refrão, em vez de se concretizar a ideia de expansão e ampliação da carga dramática, Maria Bethânia realiza um movimento contrário, com uma contenção na emissão que modera o fluxo tensivo e redireciona a interpretação para o campo da intimidade. Embora seja possível detectar um componente de tensão na emissão dos versos "É o amor/ Que mexe com a minha cabeça e me deixa assim", o que se observa, na frase seguinte é que Bethânia atenua o gesto vocal imprimindo um pouco de ar na voz: "Que faz eu pensar em você e esquecer de mim". Isto vai revelar novamente o sujeito modalizado pelo /ser /submetido à paixão, mas em estado de conjunção, celebrando a presença da mulher amada. Esse comportamento que se altera entre a tensão e o relaxamento vocal são repetidos nos demais versos que compõem o refrão, fazendo sempre reiterar no plano de expressão o sentido configurado no plano de conteúdo (MACHADO, 2012, p. 95).
}

Podemos ver, sobretudo no trecho acima, que no que diz respeito à significação, não houve novos efeitos de sentidos relacionados a outro enunciador, dentro do plano do conteúdo verbal, como nos casos analisados por nós. O que vimos no trecho acima, em termos de plano de conteúdo, foi a ocorrência de uma mudança no estado do sujeito, que passou a estar em conjunção com a amada. Entretanto, a própria autora afirma que houve uma reiteração no plano de expressão do que já se encontrava no plano de conteúdo. 
Acreditamos que análises como essas possam revelar um auctor intérprete de determinada obra. Ou seja, o Opus, em casos como o citado por Machado (2012), é apreendido basicamente por elementos cujas análises, ou apenas impressões, em casos de não especialistas, são verificadas a partir de componentes que compõem o canto. Trata-se, portanto, de componentes técnicos da atividade de cantar. Entrariam aí, também, os arranjos, a presença no palco etc., mas não questões como a escolha de temas e figuras, compondo formações ideológicas específicas, como acontece com os compositores e/ou letristas e em casos muito especiais de intérpretes, como o de Maria Bethânia.

Assim, quando defendemos que a intérprete Maria Bethânia possui um éthos de sujeito erudito-popular com dimensões autorais, trata-se de um caso particular de auctor que denominaremos auctora de canções-poemas. Nesse caso, reconhecemos a necessidade de a autoralidade de Maria Bethânia passar a ser reconhecida por terceiros.

Ainda que esse fenômeno seja bastante complexo para ser percebido por alguns críticos, professores etc., vale a pena ressaltar o que disse, em entrevista ao programa Sem Censura, a atriz e diretora de teatro Bibi Ferreira, sobre o "caso" Maria Bethânia: "e agora que ela é poeta também... nesse último disco seu... estou dizendo, porque você é poeta... agora você está escrevendo... pelo menos foi o que eu ouvi... no último disco... que é primoroso, maravilhoso, emocionante" ${ }^{53}$. Ou seja, Bibi Ferreira reconhece, no trabalho de Bethânia, o estatuto social de auctor de poesia, o que está relacionado, portanto, não apenas a elementos que compõem o canto, como na tese de Machado (2012), mas também ao plano de conteúdo. No caso, a diretora e atriz de teatro fazia referência, mais especificamente, ao CD Brasileirinho, levando em conta tanto as citações de poemas como de outros gêneros.

Porém, esse "posicionamento de terceiros" não é o mais frequente. Em geral, a postura mais corrente é tomar as canções-poemas de Maria Bethânia como mais um elemento na/da produção do espetáculo, como se vê no excerto a seguir:

\footnotetext{
Determinada, suas escolhas são tomadas de acordo com suas ambições artísticas. Assim, tornou-se não só uma grande intérprete de canções, como também da palavra falada. Bethânia sabia que o verso cantado não daria conta do que almejava no palco. Por isso, começou a levar textos, fossem prosa ou poesia, para os seus espetáculos, o que acabou se transformando numa marca registrada das suas apresentações (SABINO, 2010, p. 19).
}

\footnotetext{
${ }^{53}$ Entrevista realizada por Leda Nagle no Especial Sem Censura de dezembro de 2006, com vários convidados, entre os quais Bibi Ferreira e a própria Maria Bethânia. O programa foi exibido pela TV Brasil. Disponível em: <http://www.youtube.com/watch?v=SGGCpnt_i0A>. Acesso em: 15 out. 2012.
} 
Aqui temos que chamar a atenção para a própria seleção do corpus desta pesquisa. Como vimos, o fenômeno que denominamos canções-poemas não ocorre apenas em discos ao vivo, que poderiam ser vistos como registros dos espetáculos realizados pela intérprete. Aliás, a ocorrência em disco de estúdio reforça a tese de que a canção-poema é um novo texto, de autoria de Maria Bethânia. Se tomarmos como exemplos as canções-poemas Pátria minha/Melodia sentimental e $O$ rio/ Francisco, Francisco, veremos que elas foram lançadas primeiramente em CD de estúdio, e, apenas posteriormente, em DVD e CD ao vivo, como produtos (resultados) de shows. Com isso, podemos nos perguntar: seria a canção-poema um outro (novo) gênero que circula, inclusive, em diferentes suportes? Retomaremos essa questão no próximo item, mais com o intuito de problematizá-la do que de resolvê-la, como se verá.

\subsection{Discussão de algumas problemáticas voltadas para o estudo dos gêneros de discurso}

As análises realizadas até aqui mostram que a hibridização, num mesmo espaço textual, dos gêneros canção e poema, realizada pela intérprete Maria Bethânia gera novos e mais complexos efeitos de sentidos, o que, a nosso ver, não deixa intactas as cenas genéricas convocadas. Ao contrário, a complementaridade textual sugerida por Maria Bethânia revela que a intérprete indaga não só o gênero canção, mas também o gênero poema. Acontece que a ECP sugere a valorização de três práticas discursivas: leitura de poema, audição (leitura) da canção e leitura-audição da canção-poema.

Nessa perspectiva, uma das respostas possíveis para o questionamento feito no final do item 3.3., é a de que, por se tratar de três práticas discursivas diferentes, com suas próprias especificidades, estaríamos diante também de três gêneros discursivos distintos. Algumas características dos dois primeiros (poema e canção) já foram expostas anteriormente (ver item 1. 2). No caso da canção-poema, julgamos estar diante de um novo gênero pelo fato de nela podermos visualizar novos dispositivos sócio-históricos, condicionados por um contrato (ou jogo, ou ritual) regido pelo enunciador da canção-poema. Destacaremos alguns elementos desse jogo discursivo. 
Um elemento importante na constituição do gênero canção-poema é o seu processo de hibridização. Se tal fenômeno ocorre, com frequência, em diversas práticas discursivas, há que se considerar, no entanto, que, no caso da canção-poema, parece tratar-se de um "novo" processamento de escrita ${ }^{54}$, em que a forma de citação evidencia uma escrita em "estado bruto", sendo a organização textual vista sob um ponto de vista incipiente, em que os leitores/ouvintes são convidados a supor (e fazer) as transições que se impõem entre os elementos postos em presença do outro (COMPAGNON, 2007, p. 39).

Por isso mesmo, chamamos a atenção para um dado muito simples da construção composicional dos gêneros de discursos, exposta pelo próprio Bakhtin (2003, p. 284-285). Para ele, nos gêneros da "conversa mundana" a construção composicional resume-se à habilidade do sujeito de tomar a palavra, ou seja, "de começar corretamente e terminar corretamente". Esse parâmetro é essencial no gênero canção-poema (embora, é claro, seja apenas um pequeno dado de toda complexidade de sua construção composicional), pois as transições mais básicas que os interlocutores serão convocados a fazer estão ancoradas, justamente, na compreensão da reorganização do discurso (em termos muito simplificado e parcial: seu início, meio e fim).

Essa forma de articulação textual, no entanto, problematiza aspectos de suma importância nesses gêneros (de discursos) literários. De fato, não podemos dizer, por exemplo, que o estilo do poema foi empregado no gênero canção, substituindo, assim, o estilo desse último (ou vice-versa). Na verdade, a articulação textual mobilizada por Maria Bethânia contrasta vários estilos autorais - pensando-se na diversidade de autores mobilizados pela intérprete - organizando-os em um novo estilo: o estilo (autoral) das canções-poemas.

Isso sugere, portanto, que estamos diante de um novo gênero discursivo - na verdade, de um gênero discursivo emergente no domínio literário -, com estilo e construção composicional próprios, já que ECP também imprime à canção-poema uma organização textual específica, que a distingue do poema e da canção tomados de forma isolada. Lembremos que o estilo verbal e a construção composicional formam, junto com o conteúdo temático, a tríade que caracteriza os diferentes gêneros de discurso no entender de Bakhtin (2003).

\footnotetext{
${ }^{54}$ De acordo com Compagnon (1996, p. 38), "o trabalho da escrita é uma reescrita já que se trata de converter elementos separados e descontínuos em um todo contínuo e coerente, de juntá-los, de compreendê-los (de tomálos juntos), isto é, de lê-los". É exatamente o que faz Maria Bethânia. Entretanto, o "novo", é que ela mostra uma parte do descontínuo, evidenciando a citação em "estado bruto".
} 
Além disso, há uma certa estabilidade na consolidação de uma cena englobante única, que neutraliza a bipolarização entre literatura e paraliteratura (ou literatura de massa). Essa questão, apresentada em outras partes deste trabalho, merece aqui uma discussão mais aprofundada. Acreditamos que há, no imaginário social, um posicionamento frente ao gênero canção que não o considera como literatura. Os próprios termos "paraliteratura" e "literatura de massa" indicam essa posição. Outros fatores convergem para esse posicionamento. Por exemplo, Lajolo (1995, p. 21) lembra que a escola teve (e, a nosso ver, continua tendo) um papel de legitimação relacionado à determinação de uma obra como sendo (ou não) literatura, além, naturalmente, da própria qualificação boa/má literatura. No entanto, vemos, no excerto a seguir, uma tentativa de legitimar o gênero canção no espaço escolar:

\footnotetext{
Sem desmerecer o trabalho com a poesia, gênero que já tem sido trabalhado predominantemente na escola e nos livros didáticos, cabe ao professor abrir-se também para o universo da canção, sem a necessidade de contraposição ou dominação de um sobre o outro. Afinal, trata-se de dois gêneros que têm estrutural e historicamente forte parentesco, sendo tão próximos que é necessário diferenciá-los (COSTA, 2002, p. 121).
}

Vemos, assim, que, no contexto escolar, o gênero canção não teve (e ainda não tem) um espaço tão privilegiado quanto outros gêneros literários, como é o caso do conto, da crônica e do próprio poema, já consagrados como literatura no consenso social. Assim, poderíamos dizer que os gêneros canção e poema pertencem a domínios discursivos diferentes (ainda que próximos), o que nos levaria a atribuir à canção-poema uma espécie de cena englobante única, como propusemos acima. A não ser que levemos em conta o fato de o próprio termo literatura ser entendido a partir de pontos de vista muito distintos. Podemos, por exemplo, compreender literatura na acepção proposta por Cândido (1995, p. 242):

Chamarei literatura, da maneira mais ampla possível, todas as criações de toque poético, ficcional ou dramático em todos os níveis de uma sociedade, em todos os tipos de cultura, desde o que chamamos folclore, lenda, chiste, até as formas mais complexas e difíceis da produção escrita das grandes civilizações.

Esse conceito de literatura torna o domínio discursivo (ou cena englobante) literário mais abrangente. Nesse caso, não haveria necessidade de inserirmos o gênero canção - e, consequentemente, o gênero canção-poema - num outro domínio discursivo: bastaria falar em domínio literário (em sentido amplo). Teríamos, portanto, duas possibilidades, dependendo da acepção - mais restrita ou mais abrangente - em que se toma o termo literatura. Isso, no entanto, não descaracterizaria nossa proposta de considerar a cançãopoema como um novo gênero (emergente) de discurso. 
Como mostra Marcuschi (2002, p. 20-21), os novos gêneros que vão surgindo não são inovações absolutas; eles se ancoram em outros gêneros já existentes. O próprio Bakhtin, segundo o autor, falava na "transmutação" de gêneros e na assimilação de um gênero por outro, gerando novos. Um exemplo muito simples é o do e-mail (ou correio eletrônico) que tem nas cartas e nos bilhetes seus antecessores. Porém, como nos adverte Marcuschi, esses novos gêneros têm identidade própria. Essa postura corroboraria nossa proposta de tomar a canção-poema, não mais como uma simples forma de hibridização (articulação, junção etc.), mas como um novo gênero, na medida em que ele assimila contribuições de outros gêneros já existentes - da canção e do poema - mas possui identidade própria.

Lembremos ainda que as restrições para a proposição de um gênero discursivo são vistas, sobretudo, na perspectiva das práticas sociais. Assim, quando defendemos que a canção-poema apresenta um caráter erudito-popular, consideramos que os sujeitos envolvidos em sua prática levariam esse fato em consideração. É justamente isso que percebemos neste trecho de Cândido (2005, p. 256-257):

\begin{abstract}
A organização da sociedade pode restringir ou ampliar a fruição deste bem humanizador. $\mathrm{O}$ que há de grave numa sociedade como a brasileira é que ela mantém com a maior dureza a estratificação das possibilidades, tratando como se fossem compressíveis muitos bens materiais e espirituais que são incompressíveis. Em nossa sociedade há fruição segundo as classes na medida em que um homem do povo está praticamente privado da possibilidade de conhecer e aproveitar a leitura de Machado de Assis ou Mário de Andrade. Para ele, ficam a literatura de massa, o folclore, a sabedoria espontânea, a canção popular, o provérbio. Estas modalidades são importantes e nobres, mas é grave considerá-las como suficientes para a grande maioria que, devido à pobreza e à ignorância, é impedida de chegar às obras eruditas.
\end{abstract}

Essa privação ao conhecimento erudito é posto em xeque na canção-poema. $\mathrm{Na}$ realidade, tal privação é excluída ou, pelo menos, minimizada nessa prática discursiva. $\mathrm{O}$ rompimento se dá através de um elemento essencial, que é um traço distintivo entre o poema e a canção: como vimos anteriormente - e o último trecho de Cândido (2005) o reafirma -, a canção é produto de uma sociedade de consumo, enquanto o poema é uma prática individualizada e erudita. 
Tais aspectos contribuiriam, a nosso ver, para sustentar a tese aqui levantada de o surgimento da canção-poema remeter a um novo gênero (de discurso) literário. Principalmente porque isso mostra que sua circulação ocorre de forma distinta da dos gêneros poema e canção enquanto práticas discursivas individualizadas. Embora não haja espaço para tratarmos dessa questão da forma como ela exige, lançamos a hipótese de que a canção-poema não tem uma circulação tão ampla $^{55}$ como a canção, mas também não circula de forma tão restrita como o poema. Está, pois, restrito ao espaço de circulação de shows e de CDs e DVDs, gravados ao vivo ou em estúdio, não chegando a circular (pelo menos da forma como a canção circula) em rádios, filmes, novelas etc. Ainda que essa hipótese deva ser verificada com mais precisão, acreditamos que ela já seja um primeiro e importante passo para a abordagem de fatos como os que foram levantados nesta seção.

Sabemos, porém, o quão complexo é postular o surgimento de um novo gênero de discurso, sobretudo em se tratando do domínio literário. De fato, estamos cientes de que poderá haver contra-argumentos relativos ao nosso posicionamento, com base, inclusive, no conhecimento, por exemplo, da prática trovadoresca. Porém, se levarmos em conta que a obra trovadoresca foi retomada pela literatura, vemos que, nas canções-poemas, faz-se o caminho inverso: é a literatura que está sendo retomada no domínio da cultura popular (já que Maria Bethânia é, antes de tudo, uma cantora/intérprete).

Na realidade, a complexidade do gênero canção-poema deve ser vista a partir das próprias problemáticas da literatura. No domínio literário, os gêneros são, de fato, de difícil estabilização. Como afirma Maingueneau (2004), nesse domínio, a própria noção de gênero é problemática. A canção-poema poderia, então, ser vista como um novo gênero justamente por isso. Esse novo gênero se caracterizaria, assim, por certas restrições/regularidades, como aquelas que apontamos, mas, sobretudo, por colocar em evidência várias problemáticas do domínio literário.

Uma dessas problemáticas pode ser vista pelo próprio ato de criação da intérprete/autora Maria Bethânia. Generalizando um pouco o que a canção-poema coloca em evidência, diríamos que essa técnica de hibridização permite-nos adentrar um mundo ficcional, no qual um destinador quer fazer o outro (destinatário) entrar em conjunção com as obras da "biblioteca babilônica" de Bethânia. Tratar-se-ia, então, em sentido mais amplo, de uma criação ficcional, em que o destinatário tentaria "formular una teoría general de la

\footnotetext{
${ }^{55}$ Essa abrangência está no modo de recepção da canção, como defende Morin (1973, p. 150), citado por Costa (2002, p. 120): ela é "o mais cotidiano dos objetos de consumo, que submete o indivíduo a um banho musical cotidiano". Já a restrição de circulação do gênero poema deve ser vista pela problemática da estratificação de classes, como a citação de Cândido (2005, p. 256-257) demonstra.
} 
Biblioteca y resolver satisfactoriamente el problema que ninguna conjetura había descifrado: la naturaleza informe y caótica de casi todos los libros ${ }^{56 "}$ (BORGES, 1941/2008, p. 89).

Por fim, postulamos o engendramento do gênero (discursivo) literário cançãopoema, porque, como procuramos descrever acima, tal gênero evidenciaria uma nova prática literária, reforçando a ideia de que a literatura "é um ato que implica instituições, define um regime enunciativo e papéis específicos dentro de uma sociedade" (MAINGUENEAU, 2001, p. 6). Entretanto, não nos esquecemos da complexidade presente nos gêneros literários, cujos estudos ainda apresentam lacunas no âmbito da análise do discurso (em sentido amplo), disciplina que pode contribuir muito para a abordagem de problemáticas relacionadas a esse tema, pois em última instância, os textos literários são produtos sociais e devem ser estudados também por esse viés.

\footnotetext{
56 "Formular uma teoria geral da biblioteca e resolver satisfatoriamente o problema que nenhuma conjetura havia decifrado: a natureza informe e caótica de quase todos os livros” (tradução nossa).
} 


\section{CONCLUSÃO}

Para fazermos um balanço da pesquisa realizada, de modo a apontar seus resultados e suas contribuições, é necessário que voltemos não apenas aos objetivos propostos na introdução deste trabalho, mas também ao próprio ato de pesquisar. Isso porque, se, de um lado, os objetivos foram essenciais para direcionar a pesquisa, de outro, a própria pesquisa fez-nos sempre voltar aos objetivos e redirecioná-los, de acordo com as necessidades que iam surgindo ao longo do processo.

Foi assim, por exemplo, que fomos levados a propor (ou, pelo menos, a tentar propor) uma definição para a canção e o poema enquanto gêneros de discurso. Esse não era um objetivo específico de nossa investigação. Entretanto, como pretendíamos estudar os processos de significação envolvidos na hibridização (junção ou articulação) da canção e do poema, encontrava-se implícita uma inevitável revisão da literatura sobre esses gêneros. Isso nos permitiu verificar a dificuldade de se encontrarem definições que pudessem ser enquadradas nos postulados de uma teoria dos gêneros no âmbito da AD (tomada em sentido amplo). O que pudemos fazer, então, foi propor algumas características dos gêneros canção e poema de modo a identificá-los e distingui-los, como se viu no Capítulo 1.

No Capítulo 2, procuramos mostrar a importância do papel da intérprete na produção de sentido, por meio da exploração do nível discursivo do percurso gerativo de sentido. Enfatizamos, assim, a interferência da intérprete no plano do conteúdo verbal da canção, questão geralmente pouco explorada, já que, em geral, a produção de sentido gerada por intérpretes no gênero canção é, frequentemente, analisada com destaque para outras categorias de análise relacionadas ao canto.

Entretanto, a relevância do Capítulo 2 não se resume ao cumprimento desse objetivo. Também nesse capítulo, mostramos os novos efeitos de sentido propiciados pela hibridização dos gêneros canção e poema. Na realidade, as análises dos temas e figuras das sete canções-poemas revelaram que, mais do que uma mera justaposição de textos, há uma sobreposição do enunciador da canção-poema (ECP) em relação aos enunciadores do poema (EP) e da canção (EC), com um reenquadramento das determinações ideológicas dos textos analisados independentemente num quadro enunciativo próprio, formando, portanto, um terceiro texto. 
Constatamos ainda, a partir da análise do corpus e de sua articulação com problemáticas relevantes da área de estudos do texto/do discurso (Capítulo 3), que a intérprete Maria Bethânia deixa transparecer no discurso de suas canções-poemas, principalmente pela disseminação de novos temas e figuras, o éthos de "erudita-carnavalesca". A essa imagem atrela-se outra: a imagem de um sujeito que, por meio do procedimento de complementaridade textual, faz uma releitura do universo cancioneiro, no qual essa prática, quando investigada, limita-se a apontar os papéis sociais de compositor e letrista. Além disso, a enunciadora da canção-poema (que coincide com a intérprete Maria Bethânia, como foi dito) neutraliza a oposição entre erudito e popular que separa, frequentemente, os gêneros poema (mais erudito, prática individualizada) e canção (mais popular, produto exclusivo de uma sociedade de consumo), criando uma expectativa de éthos (um éthos prévio) específica. Tal expectativa pode ser descrita como o reconhecimento da imagem de um sujeito "eruditopopular" que valoriza três práticas discursivas: ler poemas, escutar canções, ler/ouvir cançõespoemas.

Além dos resultados expostos no parágrafo anterior, a investigação do éthos acabou por (re)direcionar o estudo para outras problemáticas, também inseridas na grande área de análise do discurso. Assim, tomando o estilo como uma recorrência de recursos usados pelo enunciador para persuadir o enunciatário, a nossa suposição de que a hibridização gerava um estilo autoral foi confirmada, pois constatamos que o estilo da canção-poema diferencia-se do que comumente se denomina "estilo de intérprete", associado à mobilização de recursos do plano de expressão.

Outro dado, exposto, de forma mais direta, no Capítulo 3, foi a necessidade de se rever a questão da autoria do ponto de vista das canções, propondo-se, para isso, três dimensões: auctor de nível intérprete-composicional; auctor de letras de música ou auctor letrista; auctor intérprete. A relevância dessa divisão reside na necessidade de melhor compreender os diferentes papéis sociais que são assumidos na produção do gênero canção e, além disso, na abordagem da complexidade do reconhecimento auctoral (sobretudo, feito por terceiros) do/no gênero canção. Essa proposta permitiu-nos chegar ao caráter auctoral de Maria Bethânia, que deve, pois, ser vista como auctora de canções-poemas, um gênero emergente no domínio literário, já que dotado de estilo e construção composicional próprios.

A questão de a canção-poema ser um novo gênero é, na realidade, o último resultado a que chegamos. Temos consciência, no entanto, de que essa ideia precisa ser discutida e investigada de forma mais profunda, uma vez que ela não está isenta de discordâncias e críticas. Fica, portanto, esse assunto em aberto para outras pesquisas. 
Todos os resultados elencados acima nos levam a considerar o saldo deste trabalho como positivo, senão pelas modestas contribuições apontadas, ao menos pelo cumprimento dos objetivos, ainda que, devido à complexidade do fenômeno que analisamos, tivéssemos que escolher apenas algumas categorias de análise - entre muitas outras igualmente pertinentes e possíveis - para não extrapolarmos o espaço/tempo que nos foi disponibilizado para a realização desta pesquisa.

Entre as contribuições que julgamos ter dado para a área de estudos do texto/do discurso, destacamos a caracterização do éthos da intérprete Maria Bethânia como "erudito carnavalesco" e a proposição da emergência do gênero canção-poema, mesmo que esse último aspecto ainda mereça discussão, como foi dito. Acreditamos, de qualquer forma, ter contribuído para uma melhor compreensão do modo como ocorre o processamento textual em novas configurações discursivas, em propostas como a da intérprete/autora Maria Bethânia. Isso, no âmbito da análise do discurso (em sentido amplo), suscita novas questões e mostra a necessidade de que outras sejam retomadas e aprofundadas. Entre elas, citamos a hibridização, num mesmo espaço textual, da canção com outros gêneros de discurso (para além do poema); a circulação do gênero canção-poema e de outros gêneros emergentes; a abordagem das propostas de outras intérpretes/cantoras etc. 


\section{REFERÊNCIAS BIBLIOGRÁFICAS}

ALVES, Rubem. A voz do desejo. In: . O que é religião? São Paulo: Loyola, 2006. p. 83-97.

ANDRADE, Mário de. Poesias completas. São Paulo: S.A, 1955. (Obras Completas de Mário de Andrade, 2).

ANDRADE, Rafael Batista. Entre canção e poesia: textos em novas configurações na sala de aula. 2010. 50f. Monografia (Especialização). Faculdade de Letras, Universidade Federal de Minas Gerais, 2010.

. Polifonia e fluxo informacional: Bethânia reorganiza o discurso. Diálogo das Letras,

Pau dos Ferros, v.1, n.1, p. 135-145, jan./jun. 2012. Disponível em: periódicos.uern.br/índex.php/dialogodasletras/índex. Acesso em: 10 ago. 2012.

ANDRESEN, Sophia de Mello Breyner. Obra poética I. 2 ed. Lisboa: Caminho, 1991.

AZAMBUJA, Mariana P. R. de; NOGUEIRA, Conceição; SAAVEDRA, Luísa. Feminismo (s) e psicologia em Portugal. Psico, Porto Alegre, PUCRS, v.38, n. 3, p. 207-215, set./dez. 2007. Disponível em: revistaseletronicas.pucrs.br/ojs/índex.php/revistapsico/article/view File/2879/2175. Acesso em: 12 jun.2012.

BAKHTIN, Mikhail. Peculiaridades do gênero, do enredo e da composição das obras de Dostoiévski. In: BAKHTIN, Mikhail. Problemas da Poética de Dostoiévski. 2. ed. Rio de Janeiro: Fourense Universitária, 1997. p. 101-180.

Estética da criação verbal. 4. ed. São Paulo: Martins Fontes, 2003.

BARRETO, Lima. Triste fim de Policarpo Quaresma. 13. ed. São Paulo: Ática, 1994. (Coleção Grandes Mestres da Literatura Brasileira, 22).

BARROS, Diana L. Pessoa de. Estudos do discurso. In: FIORIN, José Luiz (org.). Introdução à linguística II. Princípios de análise. São Paulo: Contexto, 2003. p. 188-219.

Teoria semiótica do texto. 4 ed. São Paulo: Ática, 2008.

BERTRAND, Denis. Caminhos da semiótica literária. Bauru, SP: EDUSC, 2003.

BÍBLIA DE ESTUDO DE GENEBRA. São Paulo: Cultura Cristã, 1999.

BORGES, Jorge Luis. La biblioteca de babel (1941). In: . Ficciones. Madrid: Alianza Editorial, 2008. p. 86-99.

BUARQUE, Chico. Eu já quis ser João Gilberto. In: NAVES, Santuza Cambraia; COELHO, Frederico Oliveira; BACAL, Tatiana (orgs.). A MPB em discussão: entrevistas. Belo Horizonte: Editora UFMG, 2006.

CAETANO VELOSO: site oficial. Disponível em: www.caetanoveloso.com.br. Acesso em: 26 jan. 2013. 
CADEMARTORI, Ligia. O professor e a literatura: para pequenos, médios e grandes. Belo Horizonte: Autêntica, 2009. (Série Conversas com o Professor, 1).

CAEIRO, Alberto [Fernando Pessoa]. O guardador de Rebanhos (1911-1912). In:

Poemas completos de Alberto Caeiro. Coordenação de Daniel Louzada. Rio de Janeiro: Nova Fronteira, 2011. p. 37-79.

CAMPOS, Álvaro de. [Fernando Pessoa]. Poemas de Álvaro de Campos. (1929). São Paulo: Nacional, 2008. (Coleção Clássicos de nossa língua).

CÂNDIDO, Antonio. O direito à literatura (1988). In: Vários escritos. 3. ed. São Paulo: Duas Cidades, 1995. p. 235-264.

CARNEIRO, Cláudia; ABRITTA, Stella. Formas de existir: a busca de sentido para a vida. Revista da Abordagem Gestáltica, Goiânia, v. 14, n. 2, p. 190-194, Dez. 2008. Disponível em: pepsic.bvsalud.org. Acesso em: 17 ago. 2012.

CASCUDO, Luís da Câmara. Dicionário do folclore brasileiro. 6. ed. São Paulo: Edusp, 1988. p. 23.

CASTRO, Mary Garcia. Controle da natalidade, legalização do aborto e feminismo. Encontros com a civilização brasileira, Rio de janeiro, v. 3, n. 26 a 31, p. 223-231, 1980.

CAYMMI, Stella T. Biografia. In: Alves, Luciano (coord.). O melhor de Beto Guedes: melodias cifradas para violão, guitarra e teclado. São Paulo: Ed. Irmãos Vitale, 1997. p.9-21. Disponível em: http://books.google.com.br/books?. Acesso em: 11 out. 2012.

CHAVES, Aline Saddi. Gêneros do discurso e memória: o dialogismo intergenérico no discurso publicitário. 2010. 365f. Tese (Doutorado em Língua e Literatura Francesa) Faculdade de Filosofia, Letras e Ciências Humanas, Universidade de São Paulo, São Paulo, 2010.

CHICO BUARQUE: site oficial. Disponível em: http://www.chicobuarque.com.br/. Acesso em: 26 jan. 2013.

COMPAGNON, Antoine. O trabalho da citação. Belo Horizonte: Ed. UFMG, 1996.

COSTA, Nelson Barros. As letras e a letra: o gênero canção na mídia literária. In: DIONÍSIO, A. P. et. al. (orgs.). Gêneros textuais \& ensino. 4. ed. Rio de Janeiro: Lucerna, 2002. p. 107124.

COSTA, Sérgio Roberto. Dicionário de gêneros textuais. 2. ed. Belo Horizonte: Autêntica Editora, 2009.

CRUZ, Dílson Ferreira da. O ethos dos romances de Machado de Assis. São Paulo: Nankin/ Edusp, 2009.

DICIONÁRIO CRAVO ALBIN DA MÚSICA POPULAR BRASILEIRA. Disponível em: www.dicionariompb.com.br. Acesso em 26 jan. 2013.

DIONÍSIO, A. P. et. al. (orgs.). Gêneros textuais \& ensino. 4. ed. Rio de Janeiro: Lucerna, 2002. 
DISCINI, Norma. Ethos e estilo. In: MOTTA, Ana Raquel; SALGADO, Luciana. (orgs.) Ethos discursivo. São Paulo: Contexto, 2008. p. 33-54.

DOURADO, Henrique Autran. Dicionário de termos e expressões da música. São Paulo: Ed. 34, 2004.

FÃ CLUBE ROSA DOS VENTOS BAHIA. Disponível em: <www.mariabethania.com>. Acesso em: 26 jan. 2013.

FARACO, Carlos Emílio; MOURA, Francisco Marto de. Literatura Brasileira. 4. ed. São Paulo: Ática, 1990.

FIORIN, José Luiz. Elementos de análise do discurso. São Paulo: Ática, 1989.

Pragmática. In: (org.). Introdução à linguística II. Princípios de análise. São Paulo: Contexto, 2003. p. 161-185.

A noção de texto em Semiótica. Organon, Porto Alegre, v. 9, n. 23, p.163-173, 1995. Disponível em: http://seer.ufrgs.br/organon/article/view/29370/18060. Acesso em: 11 out. 2012.

Linguagem e ideologia. 8. ed. São Paulo: Ática, 2007. (Princípios, 137).

. A multiplicidade dos ethe: a questão da heteronímia. In: MOTTA, Ana Raquel;

SALGADO, Luciana. (orgs.) Ethos discursivo. São Paulo: Contexto, 2008a. p. 55-69.

Em busca dos sentidos: estudos discursivos. São Paulo: Contexto, 2008b.

FIORIN, José Luiz; SAVIOLI, Francisco Platão. Lições de texto: leitura e redação. 4. ed. São Paulo: Ática, 2001.

FONTANILLE, Jacques. Semiótica do discurso. São Paulo: Contexto, 2011.

GIUMBELLI, Emerson; DINIZ, Júlio C. V.; NAVES, Santuza C. (Orgs.). Leituras sobre música popular: reflexões sobre sonoridades e cultura. Rio de Janeiro: 7Letras, 2008.

GREIMAS, Algirdas J. De l’imperfection. Périgueux: Pierre Fanlac, 1987.

2011.

Algirdas J ; COURTÉS, J. Dicionário de semiótica. 2. ed. São Paulo: Contexto,

HOUAISS, Antonio; VILLAR, Mauro de Salles. Dicionário Houaiss da língua portuguesa. Rio de Janeiro: Objetiva, 2009.

JOLIVET, Régis. As doutrinas existencialistas. Porto: Tavares Martins, 1957.

KENNEDY, Michael. Dicionário Oxford de música. Tradução de Gabriela Gomes da Cruz. Lisboa: Dom Quixote, 1994.

LAJOLO, Marisa. O que é literatura. 17. ed. São Paulo: Brasiliense, 1995. (Coleção Primeiros Passos, 53). 
LARA, Glaucia Muniz Proença; MATTE, Ana Cristina Fricke. Ensaios de semiótica: aprendendo com o texto. Rio de Janeiro: Nova Fronteira, 2009. (Língua e ensino: reflexões e propostas).

Glaucia Muniz Proença et al. Transgredindo os gêneros do discurso: entre a teoria e a prática. Belo Horizonte: FALE/POSLIN/UFMG, 2010.

LIMA, Luiz Costa. A questão dos gêneros. In: LIMA, Luiz Costa (Org.). Teoria da literatura em suas fontes. Rio de Janeiro: Civilização Brasileira, 2002. v. 1, cap. 7, p. 253 292.

LOPES, Ivã Carlos. Entre expressão e conteúdo: movimentos de expansão e condensação. Itinerários. Número especial. 2003. p. 65-75.

LUFT, Lya. Secreta mirada e outros poemas. 2. ed. Rio de Janeiro: Record, 2010.

MACHADO, Regina. Da intenção ao gesto interpretativo: análise semiótica do canto popular brasileiro. 2012. 192f. Tese (Doutorado em Semiótica e Linguística geral) Faculdade de Filosofia, Letras e Ciências Humanas, Universidade de São Paulo, São Paulo, 2012. Disponível em http://www.teses.usp.br/teses/disponiveis/8/8139/tde-02082012132557/pt-br.php. Acesso em: 12 set. 2012.

MAINGUENEAU, Dominique. O contexto da obra literária: enunciação, escritor, sociedade. 2. ed. São Paulo: Martins Fontes, 2001.

Diversidade dos gêneros de discurso. In: Gêneros: reflexões em análise do discurso. MACHADO, Ida L; MELLO, Renato de (orgs). Belo Horizonte: FALE/NAD/UFMG, 2004. p. 43-58.

Discurso literário. São Paulo: Contexto, 2006.

A propósito do ethos. In: MOTTA, Ana Raquel. SALGADO, Luciana (Orgs.). Ethos discursivo. São Paulo: Contexto: 2008. p. 11-29.

Doze conceitos em Análise do discurso. Organização de Sírio Possenti e Maria Cecília P. de Souza-e-Silva. São Paulo: Parábola, 2010.

MARCUSCHI, Luiz Antonio. Gêneros textuais: definição e funcionalidade. In: DIONÍSIO, Ângela et al. (Orgs.). Gêneros textuais \& ensino. Rio de Janeiro: Lucerna, 2002. p. 19-36.

2008.

. Produção textual, análise de gêneros e compreensão. São Paulo: Parábola,

MATOS, Cláudia. N.; TRAVASSOS, Elizabeth; MEDEIROS, Fernanda. T. (orgs.). Palavra cantada: ensaios sobre poesia, música e voz. Rio de Janeiro: 7Letras, 2008.

MATTE, Ana Cristina Fricke. Abordagem semiótica de histórias e canções em discos para crianças: o disco infantil e a imagem da criança. 1998. 409 f. Dissertação (Mestrado em Semiótica e Linguística Geral) - Faculdade de Filosofia, Letras e Ciências Humanas da Universidade de São Paulo, 1998. Disponível em http://www.letras.ufmg.br/ arquivos/matte/artigos/dissAnaMatte.pdf. Acesso em: 27 nov. 2012. 
MELO NETO, João Cabral de. Psicologia da composição (1946). In: João Cabral de

Melo Neto: poesia completa e prosa. 2. ed. Organização de Antonio Carlos Secchin. Rio de Janeiro: Nova Aguilar, 2008. p. 61-78. (Biblioteca luso-brasileira: série brasileira).

. João Cabral de. O Rio (1953). In: João Cabral de Melo Neto: poesia completa e prosa. 2. ed. Organização de Antonio Carlos Secchin. Rio de Janeiro: Nova Aguilar, 2008. p. 91-119. (Biblioteca luso-brasileira: série brasileira).

MENDONÇA, Cláudia Augusta Lopes de; BARBOSA JÚNIOR, Antenor Rodrigues. Projeto de integração da Bacia Hidrográfica do Rio São Francisco com as Bacias do Nordeste Setentrional e o agravamento dos desafios existentes para o gerenciamento dos recursos hídricos brasileiros. Revista de direito ambiental, São Paulo, v. 15, n. 58, p. 86-99, abr. 2010.

MENESES, Adélia Bezerra de. Ruptura com o discurso habitual sobre a mulher. In:

Figuras do feminino na canção de Chico Buarque. 2. ed. São Paulo: Ateliê, 2001. p. 65-86.

MENEZES, Roniere. O traço, a letra e a bossa: literatura e diplomacia em Cabral, Rosa e Vinicius. Belo Horizonte: Ed. UFMG, 2011.

MIRANDA, Florencia. Marcadores de gênero: uma pista para identificar a ficcionalização de gêneros textuais? In: SIMPÓSIO INTERNACIONAL DE ESTUDOS DE GÊNEROS TEXTUAIS - IV SIGET. Anais... Tubarão: UNISUL, 2007. p. 1045-1055. Disponível em CD Rom.

MOISÉS, Carlos Felipe. Roteiro de leitura: Poemas de Álvaro de Campos de Fernando Pessoa. São Paulo: Ática, 1998.

MORAES, Vinícius de. Nova antologia poética. Organização de Antonio Cícero, Eucanaã Ferraz. São Paulo: Companhia das Letras, 2005.

MORICONI, Ítalo. Como e por que ler a poesia brasileira do século XX. Rio de Janeiro: Objetiva, 2002.

MORIN, E. et al. Televisão e canção: linguagem da cultura de massas. Petrópolis: Vozes, 1973.

NAVES, Santuza Cambraia; COELHO, Frederico Oliveira; BACAL, Tatiana (orgs.). A MPB em discussão: entrevistas. Belo Horizonte: Editora UFMG, 2006.

OLIVEIRA, Ana Maria Domingues de. As mulheres de Abril de Maria Teresa Horta. ENCONTRO PAULISTA DE PROFESSORES DE LITERAUTURA PORTUGUESA HISTÓRIA, MEMÓRIA, PERSPECTIVAS, 1., 2005, São Paulo. Anais... São Paulo: M. L. Filho, 2005, p. 7-15. Disponível em: www.fflch.usp.br/dlcv/ipg/I_EPPLP.pdf. Acesso em: 12 jun. 2012.

OLIVEIRA, Clenir Bellezi de. Arte literária Brasileira. São Paulo: Editora Moderna, 2000. $432 \mathrm{p}$.

OLIVEIRA, Solange Ribeiro de. Literatura e música: modulações pós-coloniais. São Paulo: Perspectiva, 2002. (Debates, 286). 
OMRAN, Muna. Vinicius de Moraes e Nizar Kabani na construção da mulher. Revista Lumen et Virtus, São Paulo, v.1, n. 3, p. 192-208, dez. 2010. Disponível em: http://www.jackbran.com.br/lumen_et_virtus/numero3/munaomram.html. Acesso em: 27 ago. 2012.

PERRONE-MOISÉS, Leyla. Fernando Pessoa: Aquém do eu, Além do outro. 3. ed. São Paulo: Martins Fontes: 2001.

PESSOA, Fernando. Ficções do interlúdio. (1914-1935). Organização de Fernando Cabral Martins. São Paulo: Companhia das Letras, 1998.

Odes de Ricardo Reis: obra poética III. Organização de Jane Tutikian. Porto Alegre: L\&PM, 2011. 192 p. (Coleção L\&PM POCKET, vol. 516).

PLUTARCH. Moralia. The Loeb Classical Library. vol. 3. Cambridge, Massachusetts: Havard University Press, 1961.

PRIORE, Mary del. Pequena história de amor conjugal no Ocidente Moderno. Estudos de Religião, Ano XXI, n.33. São Paulo: Universidade Metodista de São Paulo, 2007. Disponível em: https://www.metodista.br/revistas/revistas-ims/index.php/ER/article/view/191. Acesso em: 23 ago. 2012.

REZENDE, Jussara Neves. A simbolização nas imagens poéticas de Cecília Meireles e Sophia de Mello Breyner Andresen: tempo e espaço. 2006. 158 f. Tese (Doutorado em Estudos Comparados de Literaturas de Língua Portuguesa) - Faculdade de Filosofia, Letras e Ciências Humanas, Universidade de São Paulo, São Paulo, 2006. Disponível em: http://www.teses.usp.br/teses/disponiveis/8/8156/tde-22082007-141356/es.php. Acesso em: 17 ago. 2012.

RIBEIRO, Cristina Betioli. Folclore e Nacionalidade na Literatura Brasileira do século XIX. Tempo, Rio de Janeiro, v.10, n. 20, p. 143-158, 2006. Disponível em: readlyc.cuamex.mx/src/inicio/ArtPdfRed.jsp?iCve=167013396008. Acesso em: 12 jun. 2012.

SABINO, Paulo. A rainha da voz. Revista união brasileira de compositores. Rio de Janeiro, n. 4, p. 19, jan. 2010.

SANTOS, Luís Alberto Brandão; OLIVEIRA, Silvana Pessôa de. Sujeito, tempo e espaço ficcionais: introdução à teoria da literatura. São Paulo: Martins Fontes, 2001. (Textos e Linguagem).

SEM CENSURA. Disponível em: <http://www.youtube.com/watch?v=SGGCpnt_i0A > Acesso em: 15 out. 2012.

SÍTIO DO MUSEU VILLA-LOBOS. Disponível em: http://www.museuvillalobos.org.br/. Acesso em: 29 jan. 2013.

SOARES, Angélica. Gêneros literários. 6. ed. São Paulo: Ática, 2000.

SOARES, Magda. Prefácio. In: CADEMARTORI, Ligia. O professor e a literatura: para pequenos, médios e grandes. Belo Horizonte: Autêntica, 2009. (Série Conversas com o Professor, 1). 
TATIT, Luiz. Musicando a semiótica: ensaios. São Paulo: Annamblume, 1997.

TINHORÃO, José Ramos. As origens da canção urbana. São Paulo: Ed. 34, 2011.

WIKIPEDIA. Disponível em: http://pt.wikipedia.org/wiki/Alberto_Ribeiro. Acesso em: 26 jan. 2013.

WIKEPEDIA. Disponível em: http://en.wikipedia.org/wiki/Victor_Herbert. Acesso em: 26 jan. 2013.

ZANELLA, Cris. O nome do livro. Disponível em: http://sebozanella. blogspot.com.br/ 2011/10/dora-vasconcelos-poetisa_17.html. Acesso em: 26 jan. 2013. 


\section{REFERÊNCIAS FONOGRÁFICAS}

BETHÂNIA, Maria. Texto $\mathrm{n}^{\circ} 2 /$ Doce mistério da vida. Intérprete: Maria Bethânia. In: Rosa dos ventos show encantado. (1971) Manaus: Universal Music, 2011. 1 CD. Faixa 6.

Rosa dos ventos show encantado. (1971) Manaus: Universal Music, 2011. 1 CD.

Texto E depois de uma tarde/Amor de Índio. Intérprete Maria Bethânia. In:

Maricotinha ao vivo. São Paulo: Biscoito Fino, 2002. Faixas 22-23.

Drama $3^{\circ}$ ato Ao vivo. Manaus: Universal Music, 1973. 1 CD.

. Eros e Psique / Tigresa. Intérprete Maria Bethânia. In: . Pássaro da manhã. Manaus: Universal Music, 1977. 1 CD. Faixas 1-2.

Pássaro da manhã. Manaus: Universal Music, 1977. 1 CD.

. Texto 4 - Extraído do poema "Aniversário" - Álvaro de Campos / Uma canção desnaturada. In: Imitação da vida. Guarulhos: EMI Music Brasil, 1997. 2 CD. Faixa 10, CD 1.

Imitação da vida. Guarulhos: EMI Music Brasil, 1997. 2 CD.

. Maricotinha ao vivo. Rio de Janeiro: Biscoito Fino, 2002. 2 CD.

. Brasileirinho. Rio de Janeiro: Biscoito Fino, 2003. 1 CD.

. Pátria Minha/Melodia sentimental. Intérprete Maria Bethânia. In:

Brasileirinho. Rio de Janeiro: Bicoito Fino, 2003. 1 CD. Faixas 11-12.

. Tempo, tempo, tempo, tempo. Rio de Janeiro: Biscoito fino, 2005. 1 videodisco.

. Brasileirinho ao vivo. Rio de Janeiro: Biscoito fino, 2004. 1 videodisco.

. Texto de Mario de Andrade/O Canto do Pajé. Intérprete Maria Bethânia.

In: BETHÂNIA, Maria. Maria Bethânia 25 anos. (1990). Manaus: Universal Music, 2006. 1 CD. Faixa 1.

Maria Bethânia 25 anos. (1990). Manaus: Universal Music, 2006. 1 CD.

Maria Bethânia Pirata. São Paulo: Quitanda, 2006a. 1 CD.

Maria Bethânia Mar de Sophia. Rio de Janeiro: Biscoito Fino: 2006b. 1 CD.

Dentro do mar tem rio. Rio de Janeiro: Biscoito Fino, 2007. 2 CD. 
BETHÂNIA, Maria. O rio/Francisco, Francisco/Meu divino São José. Intérprete Maria Bethânia. In: Dentro do mar tem rio. Rio de Janeiro: Biscoito Fino, 2007. 2 CD.

Faixas 19-20.

BUARQUE, Chico. Uma canção desnaturada. Intérprete: Chico Buarque. In: BUARQUE, Chico. Opera do malandro. Manaus: Polygram/Philips, 1979. 1 CD. Faixa 4.

GUEDES, Beto; BASTOS, Ronaldo. Amor de índio. Intérprete: Beto Guedes. In: GUEDES, Beto. Amor de Índio. Três Pontas: EMI Music, 1978. 1 CD. Faixa 1.

LOBOS, Villa; BARROS, C. Paula. O canto do Pajé. Intérprete: Maria Bethânia. In: BETHÂNIA, Maria. Maria Bethânia 25 anos. (1990). Manaus: Universal Music, 2006. 1 CD. Faixa 1.

MENDES, Roberto; CAPINAN, José Carlos. Francisco, Francisco. Intérpretes: Geraldo Azevedo e Roberto Mendes. In: AZEVEDO, Geraldo. Salve São Francisco. Rio de Janeiro: Biscoito Fino, 2011. 1 CD. Faixa 6.

VELOSO, Caetano. Tigresa. Intérprete: Caetano Veloso. In: Bicho. Manaus: Universal Music, 1977. 1 CD. Faixa 7.

VILLA-LOBOS, Heitor; VASCONCELLOS. Melodia sentimental. Rio de Janeiro: Ed. Addaf, 1969. 